\title{
PARTICIPAÇÃO DAS APOSENTADORIAS E PENSÕES NA DESIGUALDADE DA DISTRIBUIÇÃO DA RENDA NO BRASIL NO PERÍODO DE 1981 A 2001
}

\section{CARLOS ROBERTO FERREIRA}

\author{
Tese apresentada à Escola Superior de Agricultura \\ "Luiz de Queiroz", Universidade de São Paulo, \\ para obtenção do título de Doutor em Ciências, \\ Área de Concentração: Economia Aplicada.
}

P I R A C I C A B A

Estado de São Paulo - Brasil

Março - 2003 


\title{
PARTICIPAÇÃO DAS APOSENTADORIAS E PENSÕES NA DESIGUALDADE DA DISTRIBUIÇÃO DA RENDA NO BRASIL NO PERÍODO DE 1981 A 2001
}

\section{CARLOS ROBERTO FERREIRA}

Bacharel em Ciências Econômicas

\author{
Orientador: Prof. Dr. RODOLFO HOFFMANN
}

\author{
Tese apresentada à Escola Superior de Agricultura \\ "Luiz de Queiroz", Universidade de São Paulo, \\ para obtenção do título de Doutor em Ciências, \\ Área de Concentração: Economia Aplicada.
}

P I R A C I C A B A

Estado de São Paulo - Brasil

Março - 2003 


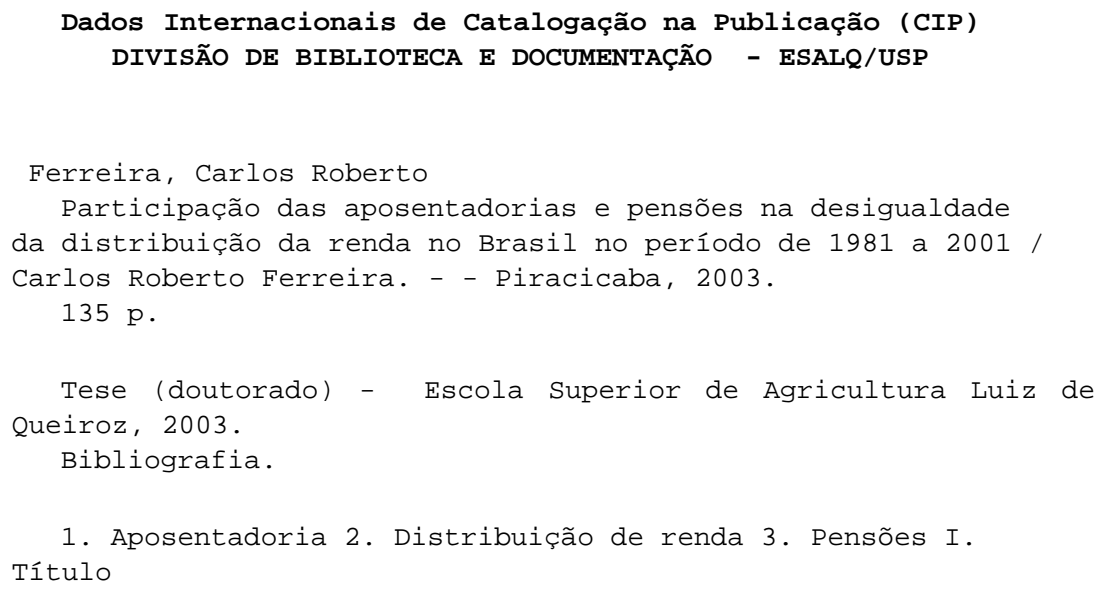

CDD 339.22

"Permitida a cópia total ou parcial deste documento, desde que citada a fonte - O autor" 
A Deus pela vida.

A meus pais, Joaquim e Alice.

A Helena e Gláucia. 


\section{AGRADECIMENTOS}

À minha esposa Helena Harumi Maruyama e a minha filha Gláucia Maruyama Ferreira, pelo apoio, compreensão e carinho;

À Escola Superior de Agricultura “Luiz de Queiroz”, Universidade de São Paulo, pela oportunidade do aprimoramento profissional;

Ao Prof. Rodolfo Hoffmann, pela valiosa orientação e apoio, que permitiram a realização deste trabalho;

Aos Professores(as) do exame de qualificação, Alexandre Lahóz Mendonça de Barros, Márcia Azanha e Angela Maria Cassavia Jorge Corrêa, pelas críticas e sugestões apresentadas;

Ao Departamento de Economia da Universidade Estadual de Londrina (UEL), pela liberação integral das minhas atividades durante o curso de doutorado;

Aos Professores e Funcionários do departamento de Economia e Sociologia Rural da ESALQ/USP, pelos ensinamentos e amizade;

A Rosa Yoshie Maruyama pela convivência e apoio ao longo dos anos;

Ao Elder, Adriana e família, pela valiosa amizade; 
Aos colegas de Pós-graduação, em especial a Cleise, Emerson, Marcos, Paula, Luiz, Carlos Estevão, Paulo Martins e Willian, pela amizade e apoio em momentos importantes durante o curso;

À CAPES, pela bolsa de doutorado. 


\section{SUMÁRIO}

LISTA DE FIGURAS........................................................................ ix

LISTA DE TABELAS.............................................................................

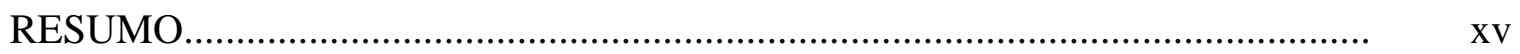

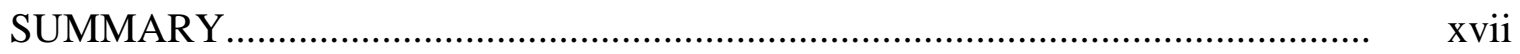

$1 \quad$ INTRODUÇÃO

1.1 Hipótese e objetivo do trabalho....................................................... 5

2 DESAFIOS E LIMITES DA PREVIDÊNCIA SOCIAL NO BRASIL...... 6

2.1 Considerações sobre a distribuição da renda no Brasil................................ 6

2.2 A Previdência Social brasileira........................................................... 12

Utilização dos gastos sociais no combate à pobreza.................................. 19

2.4 Critérios e requisitos do sistema previdenciário..................................... 25 
2.5 Mudanças demográficas..................................................................... 34

2.6 Mudanças na composição do mercado de trabalho......................................... 41

2.7 Mudanças na Constituição de 1988............................................................... 45

2.8 Reforma da previdência $\quad-$ Emenda Constitucional $\mathrm{n}^{\circ} 20 \ldots . . .47$

3 BASE DE DADOS E METODOLOGIA................................................. 52

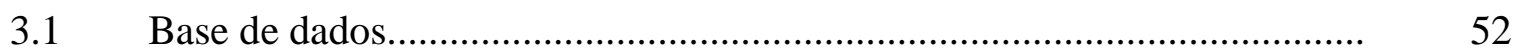

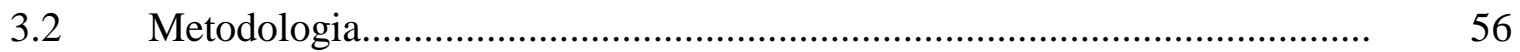

3.2.1 Medidas de desigualdade e a curva de Lorenz........................................... 57

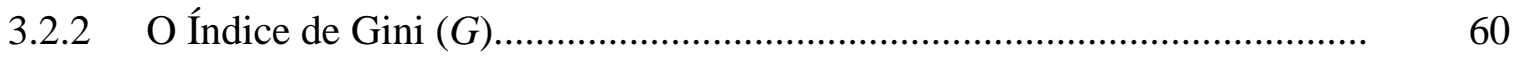

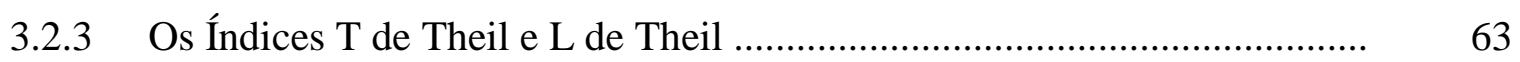

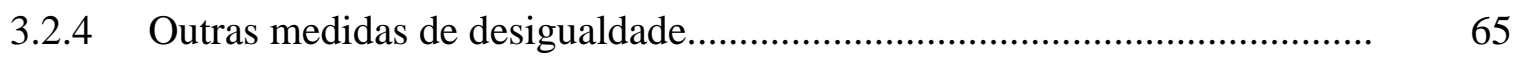

3.2.5 Decomposição do índice de Gini................................................................ 66

3.2.6 Fórmula de cálculo com ponderação e exemplo numérico de decomposição........................................................................................ 
4 EVOLUÇÃO DA DESIGUALDADE: ANÁLISE BASEADA EM ESTRATOS DO RENDIMENTO DOMICILIAR PER CAPITA E DECOMPOSIÇÃO DO ÍNDICE DE GINI.......................................... 79

4.1 Desigualdade do rendimento domiciliar per capita no Brasil: 1981 a 2001

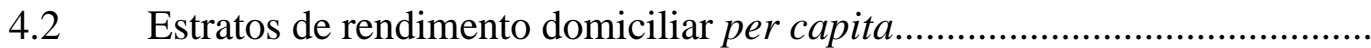

4.2.1 Distribuição do rendimento domiciliar per capita em 11 estratos, para o Brasil em 1981 e 2001

4.2.2 Estratos de rendimento domiciliar per capita agregados

4.3 Decomposição do índice de Gini

5 CONCLUSÃO. 


\section{LISTA DE FIGURAS}

Página

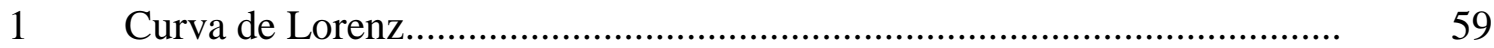

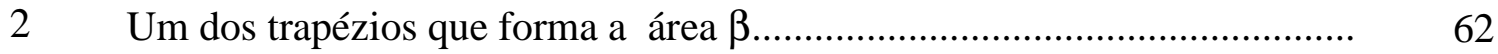

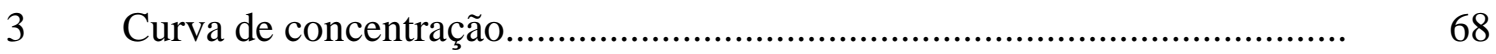

$4 \quad$ Índice de Gini, T de Theil e L de Theil. Brasil, 1981 a 2001................... 82

5 Porcentagem da renda total apropriada pelos $50 \%$ mais pobres $\left(50^{\circ}\right) \mathrm{e}$ pelos $10 \%$ mais ricos $\left(10^{+}\right)$na distribuição do rendimento domiciliar per

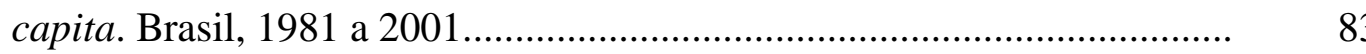

6 Participação total dos componentes do rendimento domiciliar per capita.

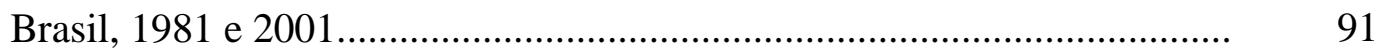

7 Participação das parcelas desagregadas de aposentadorias e pensões.

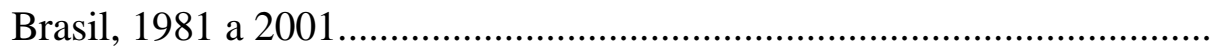


8 Percentual dos domicílios, das pessoas, de todos os trabalhos, das aposentadorias e pensões, das aposentadorias e das pensões, correspondente ao estrato de rendimento domiciliar per capita até 1 salário mínimo. Brasil, 1981 a 2001

9 Percentual dos domicílios, das pessoas, de todos os trabalhos, das aposentadorias e pensões, das aposentadorias e das pensões, correspondente ao estrato de rendimento domiciliar per capita maior do que 3 salários mínimos. Brasil, 1981 a 2001

10 Distribuição percentual do rendimento das aposentadorias e pensões para os estratos agregados de até 1 salário mínimo, com mais de 3 salários mínimos e com mais de 8 salários mínimos. Brasil, 1981 a 2001

11 Participação percentual do valor médio nos componentes do rendimento domiciliar per capita. Brasil, 1981 a 2001

12 Proporção de pessoas sem rendimentos. Brasil, 1981 a 2001

13 Razão de concentração na composição do índice de Gini do rendimento domiciliar per capita. Brasil, 1981 a 2001

14 Curvas de concentração para os componentes do rendimento domiciliar per capita. Brasil, 2001

15 Percentagens das parcelas do índice de Gini. Brasil, 1981 a 2001

16 Índice de Gini Global, parcela do índice de Gini para aposentadorias e pensões e para o trabalho principal. Brasil, 1981 a 2001 
17 Evolução da desigualdade da distribuição da distribuição da renda entre pessoas economicamente ativas com algum rendimento (PEA) e da distribuição do rendimento domiciliar per capita (RDPC) para o Brasil,

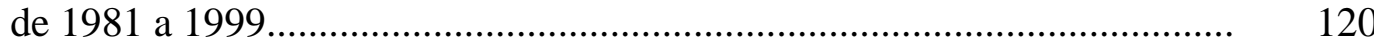




\section{LISTA DE TABELAS}

Página

$1 \quad$ Índice de Gini - Países selecionados.........................................

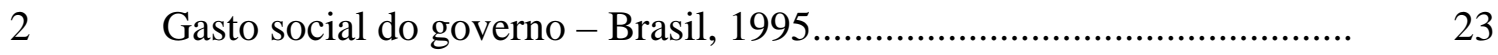

3 Curva de Lorenz e índices de desigualdade - Brasil 1997..................... 39

4 Média anual da participação dos trabalhadores com carteira assinada na população ocupada - Brasil, de 1982 a 1999 .................................... 44

5 Número total de domicílios na amostra, número de domicílios na população e o número total de pessoas, de 1981 a 2001 ......................... 55

6 Exemplo numérico artificial com 4 rendas e cálculos básicos para

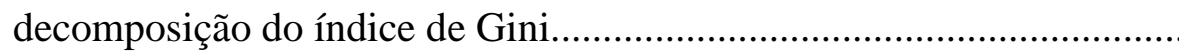

7 Distribuição dos domicílios de acordo com o rendimento domiciliar per capita, no Brasil, de 1981 a 2001: Índice de Gini (G), T de Theil (T), L de Theil (L), percentual de domicílios com rendimento igual a zero, percentagem da renda correspondente aos $50 \%$ mais pobres $\left(50^{-}\right)$ e aos $10 \%$ mais ricos $\left(10^{+}\right)$ 
8 Distribuição dos domicílios e das pessoas em estratos de rendimento domiciliar per capita. Brasil, 1981.................................................... 85

9 Distribuição de componentes do rendimento domiciliar em estratos de

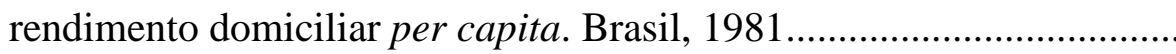

10 Participação dos componentes do rendimento domiciliar conforme estratos de rendimento domiciliar per capita. Brasil, 1981.

11 Distribuição dos domicílios e das pessoas em estratos de rendimento domiciliar per capita. Brasil, 2001

12 Distribuição de componentes do rendimento domiciliar em estratos de rendimento domiciliar per capita. Brasil, 2001

13 Participação dos componentes do rendimento domiciliar conforme estratos de rendimento domiciliar per capita. Brasil, 2001

14 Percentual dos domicílios, das pessoas, do rendimento total e dos componentes do rendimento domiciliar per capita que recebem até 1 salário mínimo. Brasil, 1981 a 2001.

15 Percentual dos domicílios, das pessoas, do rendimento total e dos componentes do rendimento domiciliar per capita que recebem mais de 3 salários mínimos. Brasil, 1981 a 2001

16 Percentual dos domicílios, das pessoas, do rendimento total, e dos componentes do rendimento domiciliar per capita, que recebem mais de 8 salários mínimos. Brasil, 1981 a 2001 
17 Decomposição do valor médio (VM) em Reais de setembro de 2001, e a participação percentual $(\% \phi)$ dos componentes do rendimento

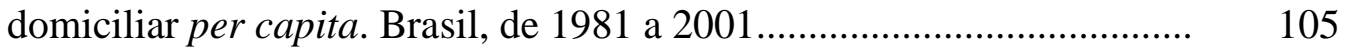

18 Índice de Gini dos componentes do rendimento domiciliar per capita, proporção das pessoas em domicílios com rendimento per capita igual a zero e proporção de pessoas sem rendimentos. Brasil, de 1981 a 2001

19 Razão de concentração (C) na decomposição do índice de Gini do rendimento domiciliar per capita. Brasil, de 1981 a 2001

20 Parcelas do índice de Gini $\left[\phi_{\mathrm{k}} \mathrm{C}\left(\mathrm{x}_{\mathrm{k}} \mid \mathrm{y}\right)\right]$ e o respectivo percentual na formação do índice de Gini Global dos componentes do rendimento domiciliar per capita. Brasil, 1981 a 2001

21 Índice de Gini para a distribuição do rendimento das pessoas economicamente ativas $\left(\mathrm{G}_{\mathrm{PEA}}\right)$ e para a distribuição do rendimento domiciliar per capita $\left(\mathrm{G}_{\mathrm{RDPC}}\right)$. Brasil, de 1981 a 1999 


\title{
PARTICIPAÇÃO DAS APOSENTADORIAS E PENSÕES NA DESIGUALDADE DA DISTRIBUIÇÃO DA RENDA NO BRASIL NO PERÍODO DE 1981 A 2001
}

\author{
Autor: CARLOS ROBERTO FERREIRA \\ Orientador: Prof. Dr. RODOLFO HOFFMANN
}

\section{RESUMO}

O modelo de financiamento do sistema previdenciário brasileiro é o de repartição simples, bastante sensível a mudanças estruturais de caráter econômico. Algumas dessas mudanças estruturais que afetaram a previdência, tiveram origem na Constituição de 1988, no crescente envelhecimento da população, no aumento da informalidade de vínculo trabalhista e em problemas políticos e administrativos no regime de previdência. Tais mudanças levaram a previdência a apresentar déficits elevados a partir de meados dos anos 90. Verificou-se que alguns princípios previdenciários como solidariedade, redistribuição e equiidade não foram respeitados. Observou-se a existência de distorções no valor de aposentadorias e pensões, privilegiando poucos e evidenciando a existência de problemas no modelo de repartição simples. Este trabalho teve como objetivo principal verificar se o rendimento das aposentadorias e pensões contribuiu para aumentar a desigualdade da distribuição de renda no Brasil. Utilizou-se a metodologia de decomposição do índice de Gini, que consiste em determinar a contribuição de cada parcela do rendimento para a desigualdade total, utilizando-se os dados da Pesquisa Nacional de Amostras Domiciliares (PNAD) de 1981 a 2001. Através dos estratos de rendimento domiciliar per capita agregados, verifica-se que a participação do estrato no 
rendimento de aposentadorias e pensões é, em geral, maior do que a sua participação no rendimento de todos os trabalhos. Nota-se também que a razão de concentração de aposentadorias e pensões, ao longo do período analisado, é superior à razão de concentração do rendimento do trabalho principal em nove dos dezesseis anos analisados. No período de 1998 a 2001 a razão de concentração de aposentadorias e pensões é superior ao índice de Gini e à razão de concentração do rendimento de trabalho principal. Observou-se que, ao longo do período analisado, aumentou a participação de aposentadorias e pensões na renda total, e a sua razão de concentração cresceu. O rendimento de aposentadorias e pensões contribuiu com a segunda maior parcela na formação do índice de Gini. Essa participação teve significativo aumento a partir de 1993. Os resultados permitem concluir que a parcela de rendimento das aposentadorias e pensões contribuiu para aumentar a desigualdade da distribuição da renda no Brasil em seis dos dezesseis anos analisados. Observa-se que de 1998 a 2001 essa contribuição tem-se intensificado. A persistência dessa situação é insustentável para o país, porque inviabilizará a Previdência Social, devido ao déficit crescente que onera as contas públicas e também porque não é justificável que rendimentos diretamente controlados pelo Estado, como as aposentadorias e pensões, contribuam para aumentar a desigualdade da distribuição da renda no país. Isso mostra que existe necessidade de reforma do sistema previdenciário brasileiro. 


\title{
THE PARTICIPATION OF RETIREMENTS AND PENSIONS IN THE INEQUALITY OF INCOME DISTRIBUTION IN BRAZIL FROM 1981 TO 2001
}

\author{
Author: Carlos Roberto Ferreira \\ Adviser: Prof. Dr. Rodolfo Hoffmann
}

\section{SUMMARY}

The financing model of the Brazilian social security system is that of simple partition, quite sensitive to economic structural changes. Some of the structural changes which affected social security were originated in the 1988 Constitution, in the increasing population aging, in the rise of employment relationship informality, and in political as well as administrative problems concerning the social security system. Such changes led social security to present high deficits from middle 1990s on. It was verified that some principles for social security, such as solidarity, re-distribution, and equality, were not respected. The existence of distortions in retirement and pension values were observed, giving privilege to few people and evidencing the existence of problems in the model of simple partition. The present work aimed primarily at verifying whether the retirement pension income contributed to increase the inequality in the income distribution in Brazil. The methodology employed was that of decomposition of Gini's index, which consists in determining the contribution of each income part to the total inequality, using data provided by Household Samples of National Research from 1981 until 2001. By means of aggregated per capita household income layers it was verified that the participation of the layer in the pension income is, in general, higher than its 
participation in the income of all works. It may be observed that the retirement and pension concentration ratio, along the period analyzed, is higher than the main work income concentration ratio in nine of the sixteen years under analysis. In the period that ranges from 1998 until 2001, the retirement and pension concentration ratio is higher than Gini's index and the main work concentration ratio. It was observed that, along the period analyzed, the participation of pensions in the total income increased, and its concentration ratio had a rise. The retirement pension income was the second highest part in the formation of Gini's index. Such participation had a significant raise from 1993 on. Based on the results, the conclusion drawn is that the retirement pension income part contributed to increase the inequality of income distribution in Brazil in six of the sixteen years analyzed. The persistence of such situation is unsustainable for the country, since it will make Social Security unfeasible due to the increasing deficit which burdens public accounts and also because it is unjustifiable that incomes that are directly controlled by the Sate, like retirements and pensions, may contribute to the increase of inequality in the income distribution in the country. This shows that there is a need for change in the Brazilian social security system. 


\section{INTRODUÇÃO}

Os últimos anos têm sido marcados por grandes mudanças estruturais no plano econômico, principalmente no mercado de trabalho, nos sistemas financeiros, nas relações entre os diferentes mercados em níveis nacional e internacional, mas também nas áreas política e demográfica, envolvendo estrutura familiar, taxas de natalidade e taxas de mortalidade. Tudo isso exerce um forte impacto sobre os sistemas previdenciários, que vêm sofrendo grandes alterações. Essas mudanças estão presentes em diferentes países, inclusive no Brasil.

O sistema previdenciário do Brasil tem sofrido impactos significativos nas receitas e custos, devido, principalmente, a mudanças no mercado de trabalho. A arrecadação da previdência social brasileira é baseada, sobretudo, na figura do empregado com carteira assinada que, em termos percentuais, está cada vez menos presente no mercado de trabalho.

Além da composição do mercado de trabalho, fatores como as mudanças na estrutura demográfica, a nova Constituição brasileira, aprovada em 1988, e distorções no sistema previdenciário tornaram o atual sistema insustentável.

Como alguns desses fatores são dinâmicos, é necessário estar atento às projeções de renda e de emprego por longos períodos, para que se possa identificar tendências e impactos

financeiros que afetam as regras básicas do sistema previdenciário 1 . Essas regras devem ser adotadas e respeitadas, para que o sistema de previdência social funcione adequadamente, mantendo o equilíbrio do sistema. 
O Brasil gasta, proporcionalmente, mais com seus sistemas de aposentadorias do que países ricos e desenvolvidos e com maior número de idosos. A soma de gastos com aposentadorias dos servidores da união, estados e municípios e setor privado, regido pelo Instituto Nacional do Seguro Social (INSS), de acordo com Gastos (2002), corresponde a 9\% do Produto Interno Bruto (PIB), enquanto a média dos países ricos, representados pela Organização para a Cooperação do Desenvolvimento Econômico (OCDE), é de 7,4\% do PIB.

Se compararmos o Brasil com a Suécia, que apresenta um dos maiores avanços sociais do mundo, verifica-se que o seu gasto com aposentadorias corresponde a 9,2\% do PIB, sendo que $22 \%$ da sua população possui mais de 60 anos (Gastos, 2002). No Brasil, ao final da década passada, aproximadamente $8 \%$ da população possuía mais de 60 anos.

Esse exemplo serve para elucidar que o Brasil gasta muito com a previdência, mas não significa que pague valores dignos o suficiente para que a maioria dos aposentados possam viver somente com a renda das aposentadorias e pensões. Observa-se que alguns dos princípios que compõem as regras básicas do sistema previdenciário não estão sendo seguidos.

Como alerta Stephanes (1999), os sistemas previdenciários são bastante sensíveis às decisões tomadas, pois elas afetam a atual e as próximas gerações. Essa preocupação não é apenas de nações, mas também de organismos internacionais como a Organização Internacional do Trabalho e o Banco Mundial. 2

Em países como Inglaterra, Estados Unidos, Itália, Chile, entre outros, procurou-se promover a adaptação aos novos cenários, em função da evolução de variáveis demográficas, de renda e de emprego ou de distorções do sistema previdenciário.

\footnotetext{
${ }^{1}$ Eqüidade, universalidade, solidariedade e redistribuição compõem algumas das regras básicas do sistema previdenciário seguidas no mundo todo.

${ }^{2}$ Veja, por exemplo, os trabalhos de James (2002); James \& Brooks (2002); Barr (2002); Mitchell (2002); Hozmann et al. (2002).
} 
No Brasil, principalmente a partir da segunda metade dos anos 90, passou-se a dar mais atenção às alterações demográficas em um cenário no qual as pessoas passaram a viver mais e, conseqüentemente, aumentou o número de idosos e a base da pirâmide etária tem crescido mais lentamente devido à diminuição da natalidade 3 . Além disso, a base de contribuição do sistema previdenciário tem diminuído ao longo do tempo. Com a reestruturação do mercado de trabalho, a proporção entre o número de trabalhadores com contratos formais de trabalho e a população ocupada caiu quase que continuamente nos últimos anos, aumentando, em contrapartida, o número de empregados sem carteira, de autônomos, ou trabalhadores por conta própria, e o de empresários, comprometendo a arrecadação do sistema. Como o modelo de financiamento da previdência adotado é a repartição simples ${ }^{4}$, a diminuição da base de financiamento levou a um aumento do déficit previdenciário. Isso implicou na diminuição do valor médio real dos benefícios aos segurados e em aumento de impostos à sociedade.

O modelo de repartição simples, segundo especialistas, contribui para a criação de sistemas fáceis e baratos de administrar, porém, está muito sujeito a interferências políticas e administrativas, criando-se regimes especiais, o que propicia a chamada redistribuição invertida de renda, levando aqueles que ganham menos a financiar os que aposentam mais cedo e que recebem mais.

A existência de distorções no valor de aposentadorias e pensões, privilegiando minorias que recebem a maior parte da renda dos benefícios, em detrimento de uma grande maioria, evidencia a existência de problemas no modelo de repartição simples, no qual, princípios previdenciários como solidariedade e redistribuição não estão sendo

\footnotetext{
${ }^{3}$ Ver em Moreira (1997).

${ }^{4}$ Existem dois modelos de financiamento dos sistemas previdenciários: o modelo de repartição simples e o modelo de capitalização. No modelo de repartição simples, as contribuições dos atuais trabalhadores financiam as aposentadorias dos inativos, e as próximas gerações vão financiar os benefícios dos que estão contribuindo. No modelo de capitalização, a cobertura dos benefícios é feita através de uma poupança formada por contribuições do trabalhador, ou seja, cada um é responsável por sua própria aposentadoria. Não existe o compromisso intergeracional neste modelo. No entanto, o conjunto de investimentos pode ser utilizado para incentivar a poupança nacional de longo prazo e promover o desenvolvimento econômico.
} 
observados. Isso fica evidente pela falta de uniformidade de critérios e requisitos nos regimes de previdência 5 social brasileira.

Apesar de todos os problemas relacionados com a previdência social, o que se espera do Estado é a promoção da forma mais justa possível do bem-estar de todos os seus cidadãos, controlando e distribuindo os benefícios. Brant (2001a) afirma que as políticas públicas, assim como a política previdenciária, têm um papel crucial para diminuir as desigualdades, principalmente em países com má distribuição de renda.

Um sistema previdenciário moderno e eficiente pode ser usado para uma melhor distribuição de renda, não somente porque paga benefícios aos idosos, mas também por estar diretamente ligado ao governo que detém as normas e leis, e que, portanto, pode e deve atenuar desigualdades de renda. No Brasil, a existência de desigualdades está presente desde o início da nossa história, tornando-se um campo de pesquisa bastante amplo e que deve, cada vez mais, ser explorado, procurando apontar, esclarecer e informar toda a sociedade na busca de alternativas. Nesse sentido, a proposta deste trabalho é estudar a distribuição da renda das aposentadorias e pensões a partir dos anos 80 e verificar se a previdência social, encarregada de gerir tais benefícios, contribuiu para aumentar a desigualdade de renda no Brasil.

Este trabalho está dividido em 5 capítulos. O primeiro é constituído por essa introdução. No segundo capítulo, é exposta a situação do sistema previdenciário, as transformações demográficas no Brasil e a reforma da previdência. No terceiro capítulo, discute-se a origem dos dados e apresenta-se a técnica de decomposição do índice de Gini. No Quarto capítulo, mostram-se os resultados. No quinto capítulo, faz-se uma síntese do trabalho e apresenta-se a conclusão.

\footnotetext{
${ }^{5} \mathrm{O}$ sistema previdenciário brasileiro é composto de três conjuntos de regimes. No setor privado tem-se: Regime Geral de Previdência Social e Regime Complementar. No setor público tem-se os Regimes dos Servidores Públicos (União, estados, municípios e poderes executivo, legislativo e judiciário).
} 


\subsection{Hipótese e objetivo do trabalho}

Diante dos argumentos levantados, a pergunta que fica é: as aposentadorias e pensões no Brasil têm contribuído para aumentar a desigualdade da distribuição de renda? A hipótese do trabalho é que as aposentadorias e pensões não são adequadamente distribuídas, contribuindo para aumentar a desigualdade da renda no Brasil.

O objetivo central deste trabalho é avaliar a contribuição das aposentadorias e pensões para a desigualdade da distribuição do rendimento domiciliar per capita no Brasil, no período de 1981 a 2001.

Este estudo justifica-se porque procurará avaliar o grau de progressividade ou regressividade das aposentadorias e pensões na distribuição da renda ao longo das últimas duas décadas. Além disso, o estudo poderá apontar eventuais distorções nos pagamentos de aposentadorias e pensões, contribuindo para sugerir correções de foco no atendimento a pessoas que têm direito às aposentadorias e pensões, visando diminuir as desigualdades. $\mathrm{O}$ estudo também é oportuno pelo momento que passa a previdência social brasileira, que tem buscado o aprimoramento de regras de concessão e de manutenção dos benefícios previdenciários.

Diversos trabalhos, como será visto adiante, mostram que a pobreza no Brasil não é resultado necessário da escassez da renda agregada, mas depende essencialmente da desigualdade na distribuição de recursos, o que reforça a necessidade de implementação de políticas públicas com caráter redistributivo e orientadas, principalmente, para os mais pobres, o que uma vez mais ratifica a importância do estudo. 


\section{DESAFIOS E LIMITES DA PREVIDÊNCIA SOCIAL NO BRASIL}

Neste capítulo discute-se, inicialmente, a distribuição da renda no Brasil, mostrando que o país reparte muito mal a sua riqueza e por isso ocupa uma das piores posições na classificação mundial conforme desigualdade da distribuição da renda e tem uma proporção de pobres relativamente alta para seu nível de renda. A seguir, verifica-se que o país tem gasto muito dinheiro na área social a fim de reduzir a pobreza, mas não tem conseguido atingir os seus objetivos porque as políticas adotadas não têm alcançado efetivamente a população mais pobre. Adiante, discutem-se os critérios e requisitos do sistema previdenciário, as mudanças demográficas, a composição do mercado de trabalho formal, as mudanças na legislação previdenciária feitas na Constituição de 1988 e a reforma da previdência de 1998. Evidencia-se que existem graves distorções no sistema previdenciário aliadas à diminuição da base contributiva e ao aumento do número de beneficiários, culminando com o crescente déficit previdenciário.

\subsection{Considerações sobre a distribuição da renda no Brasil}

Ao completar 500 anos, o Brasil ainda precisa vencer grandes desafios econômicos. O problema econômico mais grave do país chama-se pobreza. Ao seu lado, tem-se o maior problema estrutural, que é a desigualdade da distribuição da renda.

O Brasil tem experimentado fases de crescimento e de crises, mas existe uma dificuldade notável em combater a desigualdade. 
A política econômica brasileira por diversas vezes esteve voltada para o crescimento econômico, mas isso não gerou resultados satisfatórios quanto à redução da pobreza. Ao longo do tempo, diversas mudanças estruturais e conjunturais têm ocorrido, sem que, no entanto, a desigualdade tenha dado sinal convincente de diminuição. O crescimento econômico é extremamente importante para a nação, mas não deve ser perseguido como um único fim. É necessário que o crescimento econômico de um país dê resultados ao seu povo, melhorando a qualidade de vida e amplie a liberdade econômica.

Artigo de Barros et al. (2000) mostra que o Brasil não é um país pobre, mas um país injusto, e que tem na desigualdade o principal determinante dos elevados níveis de pobreza. Barros \& Foguel (2000) argumentam que o Brasil não pode ser considerado um país pobre, pois mais de $75 \%$ da população mundial vive em países com renda per capita inferior à brasileira. Brant (2001a) mostra que a pobreza no Brasil não é resultado da escassez da renda agregada, mas da desigualdade na distribuição de recursos.

Para que as pessoas tenham acesso aos recursos necessários a um padrão de vida decente, é necessário que elas adquiram educação, emprego, saúde e renda suficiente para que possam viver com dignidade. Isso significa que, no longo prazo, o país deve se desenvolver economicamente aumentando a produção e a produtividade do sistema econômico. Mas é necessário também que se ampliem as opções oferecidas a seus habitantes, assegurando-lhes oportunidade de empregos produtivos e adequadamente remunerados. No Brasil, existe a necessidade de implementação de políticas públicas com caráter redistributivo orientadas, principalmente, para os mais pobres.

O processo de crescimento econômico, sozinho, não assegura a melhoria do nível de vida da população, apesar de ser condição necessária para o desenvolvimento humano. $\mathrm{O}$ que se tem observado nos últimos anos é que o crescimento econômico não tem garantido a geração de empregos na quantidade necessária e isso tem contribuído ainda mais para a desigualdade da distribuição da renda. 
É inegável que o crescimento da economia brasileira tem beneficiado a sua população, elevando a renda média e diminuindo o grau de pobreza. O grande problema está na distribuição da renda. Apesar dos efeitos inequivocamente positivos do crescimento econômico sobre os índices de pobreza, ela é alarmante para um país do nível de desenvolvimento produtivo do Brasil.

De acordo com o Instituto de Pesquisa Econômica Aplicada (IPEA, 1996), do Ministério do Planejamento, Orçamento e Gestão, o Brasil, no início da década de 1990, apresentou um dos maiores graus de desigualdade do mundo. Segundo esse relatório, a renda média dos $10 \%$ mais ricos é quase trinta vezes maior do que a renda média dos $40 \%$ mais pobres. Comparativamente, na Holanda, a renda média dos $10 \%$ mais ricos é quatro vezes maior que a renda dos $40 \%$ mais pobres.

Considerando os $10 \%$ mais ricos e os $40 \%$ mais pobres, os dados não deixam dúvidas da disparidade de renda entre os segmentos extremos da população brasileira. A renda média dos $10 \%$ mais ricos, no Brasil, representa 23,3 vezes a renda média dos $40 \%$ mais pobres. Na França, essa razão é de 5; nos Estados Unidos, de 7,4; na Tailândia, 10,4; no México, 15,9; Panamá, 20,6; Guatemala, 23,5 e Serra Leoa, 56,2 (Brant, 2001a).

Mankiw (1999) compara a distribuição de renda de alguns países, como Japão, Coréia do Sul, China, Estados Unidos, Reino Unido, México e Brasil. Dessa lista, o Japão é o país com a melhor distribuição de renda, pois o quinto mais rico da população tem uma renda cerca de quatro vezes superior ao quinto mais pobre. Por outro lado, o quinto mais rico do Brasil tem uma renda cerca de 30 vezes maior do que o quinto mais pobre, demonstrando o quanto a renda está concentrada.

De acordo com Brant (2001a), de 163 países analisados pelo Banco Mundial em 1999 e 2000, 32\% apresentam PIB real per capita superior ao brasileiro. O Brasil ocupa a 52 a posição no ranking mundial deste indicador, mas $59 \%$ dos países têm grau de pobreza menor do que o Brasil, colocando-o na 98ª posição do ranking da pobreza. 
O grau de pobreza no Brasil é significativamente superior à média dos países com renda per capita similar à brasileira, o que indica uma má distribuição dos recursos.

Para países com renda per capita próxima à do Brasil, como Tailândia e Malásia, a pobreza atinge menos de $10 \%$ da sua população. Essa disparidade é reforçada ao se adotar como referência países com renda significativamente inferior à brasileira, como Bolívia e Sri Lanka que, com uma renda entre US\$ 1.500 e US\$2.000, possuem um grau de pobreza equivalente a cerca de um terço do valor verificado no Brasil. O percentual de pobres no Brasil é semelhante ao de países com renda per capita muito inferior, como Etiópia e Mauritânia, cujas rendas per capita são inferiores a US\$ 500 e US\$1.000, respectivamente, enquanto a renda per capita brasileira foi de aproximadamente US\$ $4.300 \mathrm{em} 1999$ (Brant, 2001a).

O índice de Gini no Brasil é elevado, conforme pode ser visto na Tabela 1. Brant (2001a) analisou 92 países e desses, 98\% têm índice inferior ao nosso, sendo que 37 países têm seus coeficientes entre 0,30 e 0,40 .

Embora o Brasil venha gastando muito na área social, continua com uma elevada concentração de renda. De acordo com o Instituto de Estudos do Trabalho e Sociedade (IETES, 2002), cerca de 135 bilhões de reais por ano são gastos na área social ineficazmente. Esses gastos não têm reduzido a desigualdade da distribuição da renda e diminuído a pobreza, porque têm beneficiado, sobretudo, os não-pobres.

As políticas sociais brasileiras são, de fato, resultantes de um processo históricopolítico no qual a maior parte dos recursos públicos são destinados aos grupos sociais privilegiados. A fonte desse dinheiro vem de uma das mais elevadas cargas tributárias entre os países em desenvolvimento, incluindo os tigres asiáticos (IETES, 2002). 
Tabela 1. Índice de Gini - Países selecionados

\begin{tabular}{cc}
\hline Países & Índice de Gini \\
\hline República Eslovaca & 0,195 \\
Letônia & 0,285 \\
Índia & 0,297 \\
Reino Unido & 0,326 \\
Suíça & 0,361 \\
Costa do Marfim & 0,369 \\
Estados Unidos da América & 0,401 \\
Nigéria & 0,450 \\
Equador & 0,466 \\
Nicarágua & 0,503 \\
Brasil & 0,601 \\
Serra Leoa & 0,629 \\
\hline
\end{tabular}

Fonte: Brant (2001a)

Como aponta IETES (2002), nos poderes legislativo e judiciário os benefícios médios de aposentadorias são dezenas de vezes maiores que os do setor privado. Outro exemplo, porém menos conhecido, é o seguro desemprego. Do total de recursos distribuídos pelo programa, 23\% vão para os pobres e $77 \%$ para não-pobres. Entre os não-pobres que recebem seguro-desemprego, 53\% estão trabalhando e $35 \%$ estão aposentados. O valor do benefício médio do seguro-desemprego para os pobres é de cerca de 60\% dos não-pobres, conforme coloca IETES (2002,p.24):

“[...] o "funding" do seguro-desemprego não é um patrimônio que cada trabalhador paga, com recursos próprios, e que guarda uma proporcionalidade com o valor do seu salário. O programa é financiado por um imposto sobre o faturamento das empresas, pago, portanto em última instância, por todos os contribuintes. Sob este ponto-de-vista, é estranho no mínimo, que os trabalhadores com maior salário mereçam receber benefícios maiores, oriundos de recursos públicos, apenas porque desfrutam de um padrão de vida mais alto, que exige 
mais dinheiro para ser mantido. Este é um exemplo contundente que mostra como a sociedade e as instituições brasileiras legitimam e cristalizam a desigualdade".

Brant (2001a) mostra que uma divisão mais eqüitativa dos recursos pode ter um impacto relevante sobre a pobreza em um país que dispõe de uma renda per capita cerca de três vezes superior à sua linha de pobreza e seis vezes à de extrema pobrez ${ }^{6}$. Para o autor, o custo da erradicação da pobreza é relativamente baixo. O esforço para eliminação da pobreza exigiria a transferência focalizada de cerca de $R$ \$ 27,9 bilhões por ano, e no caso da erradicação da indigência, este volume seria de R \$ 14 bilhões, o que corresponde a, respectivamente, $21,4 \%$ e $10,8 \%$ do gasto social do governo federal.

Mas não basta apenas ter gasto social, que é temporário. A diminuição do problema passa por ações mais amplas, que sejam capazes de garantir a manutenção da renda dos indivíduos. Essas ações são concretizadas com políticas nas áreas de educação, saúde, geração de emprego e renda, reforma agrária, entre outras, mas que estejam em confluência com estratégias de longo prazo voltadas para melhorar a distribuição de renda.

De acordo com IPEA (1996), o efeito distributivo dos gastos sociais é reduzido, sendo seu perfil desfavorável mesmo aos contingentes mais pobres da população. Esse trabalho mostra que estimativas do Banco Mundial, referentes a 1990, indicam que o valor per capita dos gastos sociais, sem incluir os benefícios pagos pela previdência, relativos aos $20 \%$ mais pobres da população, era $13 \%$ inferior à cifra correspondente aos $80 \%$ restantes da população. Esse diferencial aumenta quando se consideram os benefícios pagos pela previdência. O valor per capita dos gastos sociais referentes aos $20 \%$ mais pobres era $40 \%$ menor do que o valor relativo aos outros $80 \%$ da população. Esses dados mostram que, quando se consideram os benefícios pagos pela previdência, o perfil de distribuição é ainda mais desfavorável aos segmentos mais pobres.

\footnotetext{
${ }^{6}$ Brandt (2001a) considerou a linha de pobreza igual a $\mathrm{R} \$ 98,00$ e a linha de extrema pobreza igual a $\mathrm{R} \$ 49,00$.
} 
É inegável que alguns programas sociais têm obtido êxito. Porém, o que não é aceitável é a baixa efetividade do gasto social brasileiro com os grupos de pobres, nos quais o acesso aos programas é menor, proporcionalmente, para os miseráveis.

Um exemplo dessa situação está no relatório IPEA (1996). As percentagens de aposentadorias e pensões na população com mais de sessenta anos nos níveis de indigência e de pobreza não-indigente são, respectivamente, de $65 \%$ e $70 \%$, num total de 4,1 milhões de pessoas. Mesmo assim, cerca de 31\% do total de idosos não recebem nenhum auxílio previdenciário. Considerando os idosos pobres, $20 \%$ deles não recebem nenhum rendimento previdenciário, com grande probabilidade, portanto, de não disporem de nenhum rendimento.

A partir da próxima seção deste capítulo, procura-se conhecer e mostrar os pontos impeditivos para uma melhor divisão da renda, ao mesmo tempo em que o país tem gasto muito dinheiro no combate à pobreza, porém sem grande eficácia.

\subsection{A previdência social brasileira}

A previdência social é uma instituição encarregada de dar seguro, através de um programa de pagamentos prestados aos indivíduos ou a seus dependentes, como compensação parcial ou total da perda de capacidade laborativa por doença, invalidez, morte (deixando pensão à sua família) ou por idade avançada, garantindo aos seus segurados os benefícios que, normalmente, são proporcionais às contribuições. A previdência social faz parte do Ministério da Previdência e Assistência Social (MPAS).

Conforme Stephanes (1999), na América do Sul, a implantação dos sistemas previdenciários ocorreu em momentos distintos, mas os seus erros e vícios foram semelhantes. De maneira geral, os sistemas surgiram a partir de demandas corporativistas, com cobertura limitada, mas com a contribuição direta ou indireta da 
sociedade. Isso resultou em sistemas ineficazes, que não atendiam aos princípios de justiça social e eqüidade.

Além disso, existia uma multiplicidade de regimes previdenciários, o que facilitava um grande número de distorções, como as enumeradas por Stephanes (1999): a) práticas patrimonialistas, clientelistas e assistencialistas; b) ingerência política, com administração não-profissional; c) introdução de novos benefícios sem a contrapartida de receita a longo prazo; d) confusão conceitual entre Previdência e Assistência Social; e) inexistência de cadastros de trabalhadores ativos e inativos; f) falta de corpo técnico qualificado, de investimentos permanentes em tecnologia, de informações e de estudos sistemáticos que dimensionem e possibilitem o controle das receitas e despesas, diminuindo as fraudes e os desperdícios, e que acompanhem o desempenho e projetem as tendências.

Essas distorções, juntamente com a instabilidade política, a informalidade estrutural da economia e as elevadas taxas de inflação nos países da América do Sul, levaram à construção de sistemas previdenciários que não tinham nenhuma preocupação com a doutrina de seguro social. Somente a partir da década de 1980 é que tiveram início algumas reformas. Até então, os diferentes governos buscaram soluções apenas para os seus modelos econômicos, deixando de observar se os princípios, as estruturas legais, administrativas, financeiras e atuariais dos sistemas previdenciários estavam corretas.

O início do sistema previdenciário brasileiro também apresentou problemas. Apesar de ele ter sido instalado na década de 1920, as regras básicas não foram observadas. Prevaleceram as interferências políticas, como o paternalismo, a proteção e os privilégios a determinados grupos ou segmentos, que tiveram maior capacidade de influência política, e que resistiram às mudanças e reformas da previdência social. Ou seja, não houve a preocupação com quem iria pagar a conta e quanto ela custaria no presente ou no futuro.

A previdência social, no mundo, inspirou-se no modelo alemão proposto pelo chanceler Otto Von Bismarck, em 1833. No Brasil, por intermédio do deputado Eloy Chaves, o Congresso Nacional criou em 1923, através do decreto legislativo $n^{\circ} 4.682$, a 
Caixa de Aposentadorias e Pensões (CAPs) para os empregados em empresas de estrada de ferro. Esses empregados e seus familiares passaram a ter direito à assistência médica, a medicamentos com preços especiais, a aposentadorias e a pensões. As CAPs eram organizações autônomas, nucleadas por empresas, organizadas pelos trabalhadores sem ingerência do Estado.

No entanto, a Caixa de Aposentadorias e Pensões era pouco abrangente e estruturalmente frágil. Muitas caixas eram organizadas por empresas e não tinham, em alguns casos, o número necessário de segurados para o estabelecimento das bases securitárias, comprometendo o pagamento dos benefícios a longo prazo.

A falta de organização e técnicas que permitissem a saúde financeira das Caixas, à medida que elas cresciam, marcaram o período inicial das Caixas de Aposentadorias e Pensões, tanto que, em 1930, o presidente Getúlio Vargas suspendeu por seis meses todas as aposentadorias em vigor, pois já era grande o número de fraudes, corrupção e perdas financeiras. Vargas iniciou uma reestruturação do sistema, incluindo praticamente todas as categorias de trabalhadores urbanos, criando grandes institutos nacionais, substituindo as Caixas de Aposentadorias. Esses institutos surgiram como instituições de previdência social de âmbito nacional, financiada pelo sistema tripartite ${ }^{7}$. empregados, empresas e governo, que centralizou a arrecadação.

De acordo com Andrade (2001, p.169), a principal diferença dos Institutos de Aposentadorias e Pensões (IAPs) para as Caixas de Aposentadorias (CAPs) foi:

“[...] ao contrário das CAP's que juridicamente eram
sociedades civis, a expansão dos IAP's representou, não só
uma resposta a demandas políticas das classes assalariadas, - e
nesse sentido foi um instrumento de incorporação política
dessas classes, mas correspondeu, - pelo lado econômico-
financeiro, a interesses bastante oportunos. A Previdência
Social transforma-se, a partir de então, em instrumento de
captação forçada de poupança, e o controle do Estado sobre as
reservas do sistema, a partir de meados de 30, transformam o

\footnotetext{
${ }^{7}$ Maiores detalhes ver em Andrade (2001) e Stephanes (1999)
} 
sistema de previdência no principal "sócio" do Estado no financiamento ao processo de industrialização do país."

Desde 1923, a previdência social brasileira passou por várias transformações. De acordo com Stephanes (1999), a partir da década de 1940, o sistema previdenciário dos trabalhadores da iniciativa privada sofreu progressiva unificação legal e institucional, homogeneizando os seus planos de custeio e de benefícios, o que culminou com o Regime Geral de Previdência Social (RGPS), operado pelo Instituto Nacional do Seguro Social (INSS), criado em 1990.

Até 1966, a previdência social urbana no Brasil ficou sob a responsabilidade dos vários Institutos de Aposentadorias e Pensões. A partir de 26/11/1966, de acordo com o Decreto-lei $n^{\circ} 72$, criou-se o Instituto Nacional de Previdência Social que absorveu estes institutos, o Serviço de Assistência Médica Domiciliar e de Urgência (SAMDU) e o Serviço de Reabilitação Profissional (Suserps). Em 01/05/1974, através da lei no 6.036, surgiu o Ministério da Previdência e Assistência Social, no qual se incluiu o Instituto Nacional de Previdência Social (INPS). Em 01/09/1977, o INPS passou a atender apenas à concessão dos benefícios, sendo criado o Instituto Nacional de Assistência Médica e Previdência Social (INAMPS) para o atendimento médico-hospitalar, e o Instituto de Administração Financeira da Previdência e Assistência Social (IAPAS), para o serviço de arrecadação. Em 15/03/1990, com o Plano Collor, formou-se o Instituto Nacional do Seguro Social (INSS) como autarquia federal, mediante fusão do IAPAS com o INPS (Sandroni, 2001).

O conjunto de reformas e alterações no sistema previdenciário, iniciadas nos anos de 1930 e reforçadas pelo Estado Novo, foi a principal força auxiliar na consolidação pública do "novo" perfil intervencionista do Estado.

"De fato, dentro do conjunto de reformas e alterações no aparelho de Estado iniciadas nos anos 30 e reforçadas no Estado Novo, a montagem de um sistema de serviços centralmente controlado, passível de extensão ao conjunto dos assalariados urbanos, - faz, do sistema previdenciário nascente, a principal força auxiliar na consolidação pública do 
"novo"perfil do Estado. A relação que se estabelece entre o Estado e as entidades previdenciárias, a partir deste momento, tem um papel definidor na constituição do sistema previdenciário que passa a vigorar a partir da primeira Lei Orgânica da Previdência Social, promulgada em 1960, que cria o Instituto Nacional de Previdência Social - o INPS, efetivamente instalado em 1966" (Andrade,2001,p.169).

Entre 1923 e 1966, aproximadamente 50\% das receitas arrecadadas não eram gastos em pagamentos de benefícios, pois o número de trabalhadores contribuintes era muito superior ao número de inativos e, como o governo tinha o controle desses saldos positivos, em diversas ocasiões foram utilizados para outras finalidades, fora do interesse previdenciário. A partir da criação do INPS, o Estado passa a ter pleno controle institucional sobre o sistema previdenciário, passando, então, a utilizar sua capacidade de arrecadação como mecanismo complementar no financiamento ao tesouro.

Stephanes (1999) mostra que os saldos da previdência foram usados, por exemplo, na construção do Distrito Federal, na constituição e no aumento de capital de várias empresas estatais, na manutenção de saldos na rede bancária como compensação pela execução de serviços de arrecadação de contribuições e de pagamento de benefícios. Observa-se que, ao longo desse tempo, não houve a preocupação em converter esses saldos em reserva capitalizada.

O sistema previdenciário montado a partir de 1966 foi caracterizado como sendo de natureza contributiva, mantida a sua forma de financiamento dependente das contribuições vinculadas às relações formais de emprego. Contudo, seguiu-se um conjunto de transformações na estrutura do sistema previdenciário, no elenco de benefícios/direitos e expansão de cobertura, sem as devidas contrapartidas, não havendo preocupações com futuros desequilíbrios fiscais.

Apesar da forma como a previdência era administrada, até o final dos anos de 1970, ela funcionou como instrumento capaz de aliviar tensões sociais devido ao processo de crescimento econômico, que era altamente excludente. Benefícios como seguro contra 
acidentes de trabalho, extensão da previdência social aos trabalhadores rurais, às empregadas domésticas e aos autônomos foram estabelecidos.

No início dos anos de 1980, a previdência social brasileira entrou em crise, devido à crescente expansão da cobertura previdenciária e assistencial, sem assegurar alterações no sentido da sustentação da base financeira. Desde os primeiros anos da década de 80, a economia brasileira estava em recessão, o nível de emprego industrial diminuiu e conseqüentemente a arrecadação previdenciária também, ou seja, a contribuição dos trabalhadores urbanos. A partir de então, a crise da previdência passa a ser não somente financeira e conjuntural, mas também estrutural.

Com a promulgação da nova Constituição brasileira em 1988, o sistema previdenciário passou por importantes mudanças, tais como a introdução da universalização da elegibilidade para mulheres e homens de sessenta e de sessenta e cinco anos ou mais, respectivamente; a criação da aposentadoria rural e o estabelecimento de piso igual ao salário mínimo vigente. Em princípio tais medidas eram bem vindas e tinham o objetivo de reduzir a pobreza e melhorar a distribuição da renda. Mas com o aumento de benefícios sem a mesma proporção de receita, a insustentabilidade do sistema previdenciário ficou patente. De acordo com Andrade (2001), dois aspectos evidenciaram a falência do sistema: uma relação extremamente baixa entre contribuintes ativos e o número de inativos e pensionistas; e um crescimento explosivo dos encargos com benefícios. Tais fatores levaram a uma crescente despesa sem a contrapartida nas receitas.

Andrade (2001) e Ornélas \& Vieira (2002) reconhecem que o mais importante componente da crise estrutural do sistema previdenciário foi o conjunto de transformações na estrutura populacional e na dinâmica demográfica, aumentando o número de beneficiários e diminuindo a base contributiva.

Para Stephanes (1999), além do fator demográfico, a falta de eqüidade e de justiça social propiciou distorções em todo o sistema previdenciário. Ele cita, como exemplo, as 
distorções nos regimes previdenciários, nas quais a minoria possui privilégios, mas é financiada por todos os trabalhadores contribuintes.

Para Brant (2001a), os fatores que provocaram a insustentabilidade do sistema previdenciário no Brasil foram as elevadas alíquotas de contribuição, que não geram incentivos à ampliação de cobertura, a concessão de aposentadorias em idades baixas, o envelhecimento da população e o fim da alta inflação, a partir de 1994.

Com projeções que indicavam a inviabilização do sistema previdenciário brasileiro, após quatro anos de discussões, foi aprovada a emenda constitucional $n_{7} 20$, em dezembro

de 1998, eliminando algumas distorções existentes nos regimes previdenciários, procurando também reduzir os dispêndios com os benefícios. O resultado foi significativo, embora aquém das necessidades de ajuste dos regimes de previdência, segundo o governo $\$$.

Enfim, constata-se que o sistema brasileiro de previdência, gerenciada pelo Estado, durante muitos anos, não observou as doutrinas, princípios e fundamentos da previdência social, como eqüidade, universalidade, solidariedade e redistribuição de renda, necessários para se ter bons sistemas previdenciários. Apesar disso, a contribuição que a previdência e a assistência social prestam ao país é notável, mas acredita-se que ela poderia e deveria ser muito melhor.

Diversos autore ${ }^{9}$ constataram que as baixas taxas de fecundidade, o aumento da longevidade e a urbanização acelerada ocorridas no Brasil, a partir da década de 60, estão refletindo, na atualidade e nas próximas décadas, em um aumento do número de idosos. Esse fenômeno está mudando o perfil das políticas públicas e aumentando os desafios sobre como enfrentar e conduzir satisfatoriamente um grande número de

\footnotetext{
${ }^{8}$ Para maiores detalhes ver Stephanes (1999) e Ornélas \& Vieira (2002).

9 Camarano (2002); Ornélas \& Vieira (2002); Andrade (2001); Fígoli (2001); Camarano (1999); Stephanes (1999); IPEA (1997); Moreira (1997).
} 
pessoas que estão ou entrarão na terceira idade, proporcionando-lhes conforto e dignidade. Esses estudos revelam que a renda média dos idosos, principalmente entre os de 60 a 64 anos, é maior do que a de jovens com menos de 30 anos e, além disso, nas famílias que são compostas por idosos, a participação de suas rendas é importante, contribuindo com cerca de $52 \%$ da renda.

Pesquisa realizada por Camarano (2002) confirma que as aposentadorias desempenham um papel muito importante na renda dos idosos, sendo crescente com a idade, mostrando como os idosos dependem dos benefícios previdenciários. Ela constata também que uma parcela importante da renda familiar depende da renda do idoso, demonstrando que aumentos ou reduções de benefícios previdenciários realizados pelo Estado não estão simplesmente atingindo indivíduos, mas uma fração razoável dos rendimentos das famílias. Em 1998, $8 \%$ da população brasileira era idosa e em $26 \%$ das famílias brasileiras podia-se encontrar pelo menos um idoso.

Naturalmente, constata-se que está havendo um aumento da participação do idoso nas atividades econômicas. Isso acontece principalmente porque os seus rendimentos passam a ser menores com a aposentadoria ou pensão, obrigando o idoso a continuar trabalhando. O idoso pobre está mais sujeito a esse problema, sendo obrigado a aceitar condições de trabalho desinteressantes e menos vantajosas.

Embora haja poucos trabalhos que discutam com profundidade o assunto, constata-se que a renda das aposentadorias e pensões no Brasil é distribuída de forma desigual entre idosos pobres e não-pobres. Isso propicia a redistribuição invertida de renda, na qual aqueles que ganham menos estão financiando os que se aposentam mais cedo e que ganham mais.

\section{3 - Utilização dos gastos sociais no combate à pobreza.}


É indiscutível que a proteção social pública para as pessoas pobres é fundamental, pois, além de propiciar o bem-estar das pessoas e famílias, promove o funcionamento da economia e da sociedade como um todo. De acordo com Thompson (2002), um sistema previdenciário bem estruturado melhora a capacidade de consumo, o funcionamento do mercado de trabalho e promove o incremento da paz social e da coesão econômica nas sociedades modernas. Apesar disso, considera-se que ele é uma das causas do desempenho econômico ruim de muitos países industrializados e em desenvolvimento.

Thompson (2002), citando o relatório do Banco Mundial de 1994, mostra que são atribuídos aos esquemas oficiais de benefícios as altas e crescentes taxas sobre a folha de pagamento, o mau emprego de recursos públicos, oportunidades perdidas de aumento da poupança a longo prazo, inexistência de redistribuição em favor dos grupos de baixos rendimentos, crescimento da dívida pública previdenciária e inviabilidade fiscal.

No Brasil, vários trabalhos discutem como os gastos com aposentadorias e pensões são mal focalizados quando considerados como gastos sociais destinados a combater a pobreza.

O trabalho de Amsberg et al. (2000), utilizando dados da pesquisa sobre padrões de vida (PPV), analisou o direcionamento à pobreza do gasto social do Brasil. Os resultados obtidos foram baseados em análises feitas nas regiões Nordeste e Sudeste que, juntas, congregam $73 \%$ da população e $80 \%$ dos pobres do Brasil. O artigo procura analisar principalmente a incidência do gasto para o quinto com menor renda da população brasileira, que representa os pobres $\stackrel{10}{ }$. Para o programa de transferência de dinheiro direcionado ao seguro-desemprego e pensões, observa a existência de concentração de benefícios nos quintos superiores, indicando que a incidência dos

\footnotetext{
${ }^{10}$ Amsberg et al. (2000) consideram a linha de pobreza baseada apenas na alimentação de R\$ 65,00 per capita ao mês, para os dados de renda familiar provenientes da Pesquisa Nacional por Amostra de Domicílio (PNAD) de 1996.
} 
benefícios é regressiva. Nos gastos sociais, de forma geral, apenas $13 \%$ atingem os pobres.

O trabalho de Ramos (2000), utilizando dados da Pesquisa sobre Condições de Vida (PCV) de 1998, mostra o impacto distributivo do gasto público, em décimos da distribuição da renda familiar per capita. Essa pesquisa foi realizada na região metropolitana de São Paulo e em seus municípios com mais de 50 mil habitantes.

A análise dos dados de pensões e aposentadorias revela que existe concentração desses benefícios no sistema público de previdência no Estado de São Paulo. Tanto a distribuição dos benefícios por décimos da distribuição da renda familiar per capita como o valor médio do benefício tendem a privilegiar as famílias de maiores rendas per capita.

Ainda segundo o referido estudo, o percentual de beneficiários do Instituto de Previdência Pública do Estado de São Paulo, distribuído por décimos da renda familiar per capita e a distribuição da massa de benefícios deixam claro a concentração. No primeiro décimo, onde se encontram os relativamente mais pobres, o número de pensionistas corresponde a $2,99 \%$ que recebem $1,34 \%$ do total desse benefício, enquanto no último décimo, onde se encontram os relativamente mais ricos, o número de pensionistas corresponde a $11,85 \%$ que recebem $32,21 \%$ do total desse benefício. Para os aposentados, no primeiro décimo são 3,07\% que ficam com 0,83\% do total desse beneficio. O último décimo é composto por $16,42 \%$ de beneficiários que ficam com $37,65 \%$ do total desse benefício.

Para Ramos (2000), a análise dos dados da PCV de 1998 sugere que o diagnóstico, segundo o qual o atual sistema previdenciário do estado de São Paulo tende a reproduzir a concentração de renda gerada pelo mercado, parece pertinente. 
A pesquisa de Barros \& Foguel (2000) mostra que, apesar do elevado grau de pobreza no país, o volume total de recursos necessários para a sua erradicação seria da ordem de R $\$ 34$ bilhões por ano, em um país que tem $\mathrm{R} \$ 800$ bilhões de renda nacional e que gasta anualmente $\mathrm{R} \$ 130$ bilhões na área social. Ou seja, seriam necessários 4\% da renda nacional, ou aproximadamente $25 \%$ dos recursos públicos destinados à área social. Esses dados revelam que os gastos sociais brasileiros representam mais de três a quatro vezes o valor necessário para erradicar toda a pobreza no país.

Segundo os referidos autores, as áreas de previdência social, benefícios a servidores, educação e cultura, e saúde representam $85,21 \%$ do total de gastos sociais no país, conforme pode ser visto na Tabela 2.

Um exemplo da má focalização dos gastos sociais pode ser encontrado na área de benefícios a servidores. Barros \& Foguel (2000) argumentam que a proporção de servidores públicos entre os pobres é seguramente bastante reduzida e que grande parte do valor gasto com benefícios aos servidores públicos não deve estar atingindo a população pobre, mostrando que correções no grau de focalização podem impactar o grau de pobreza.

No mesmo trabalho, Barros \& Foguel (2000) investigam o grau de focalização do programa de aposentadorias e pensões, baseados em informações tiradas da Pesquisa Sobre Padrões de Vida (PPV), coletadas em 1995/96, cobrindo áreas urbana e rural das regiões Sudeste e Nordeste.

Nas estimativas de Barros \& Foguel (2000) referentes ao grau de focalização das aposentadorias e pensões para a população, verifica-se que o grau de incidência do acesso ao benefício é relativamente estável, enquanto o gasto é bastante regressivo, isto é, são os mais ricos que mais se beneficiam do programa. Suas estimativas também apresentam o grau de incidência do acesso e do gasto para o universo de beneficiários potenciais, ou seja, pessoas com mais de 60 anos. Os resultados mostram uma situação 
parecida ao da população como um todo. O acesso é relativamente estável enquanto o gasto é bastante concentrado entre os mais ricos. Essa má focalização dos gastos, segundo os autores, é explicada pelo fato de o gasto por beneficiário ser maior entre os mais ricos que entre os mais pobres.

Tabela 2. Gasto social do governo - Brasil, 1995

\begin{tabular}{lc|c|c}
\hline GASTO POR ÁREA DE ATUAÇÃO & $\begin{array}{c}\text { Valores } \\
(\mathrm{R} \$ \text { milhões })\end{array}$ & \% do total & $\begin{array}{c}\% \\
\text { acumulado }\end{array}$ \\
\hline Previdência Social & 35.161 & 25,99 & 25,99 \\
Benefícios a servidores & 30.408 & 22,48 & 48,47 \\
Educação e cultura & 27.968 & 20,67 & 69,14 \\
Saúde & 21.738 & 16,07 & 85,21 \\
Habitação e urbanismo & 7.183 & 5,30 & 90,51 \\
Emprego e defesa do trabalhador & 3.022 & 2,23 & 92,74 \\
Assistência social & 2.863 & 2,12 & 94,86 \\
Transporte urbano de massa & 2.620 & 1,94 & 96,80 \\
Saneamento & 1.374 & 1,02 & 97,82 \\
Organização agrária & 1.187 & 0,88 & 98,70 \\
Alimentação e nutrição & 822 & 0,60 & 99,30 \\
Ciência e tecnologia & 494 & 0,37 & 99,67 \\
Proteção ao meio ambiente & 401 & 0,30 & 99,97 \\
Treinamento de recurso humanos & 44 & 0,03 & 100,00 \\
Total & $\mathbf{1 3 5 . 2 8 5}$ & $\mathbf{1 0 0 , 0 0}$ & $\mathbf{1 0 0 , 0 0}$ \\
\hline Fonte: Bartos \& Fog & & & \\
\hline
\end{tabular}

Fonte: Barros \& Foguel (2000)

De acordo com Barros \& Foguel (2000), a solução para o problema depende mais do aperfeiçoamento das políticas públicas do que da elevação de gastos.

Néri (2001) também discute a má focalização dos gastos sociais e reforça as conclusões de Barros \& Foguel. Ele argumenta que a dificuldade em combater a 
desigualdade da distribuição de renda não está na quantidade, mas na qualidade das ações implementadas.

Umas das distorções destacadas em seu artigo está na alocação dos gastos previdenciários em aposentadorias e pensões: "Dez por cento dos benefícios mais altos incluindo o INSS e os inativos do setor público - se apropriam de quase metade da massa de benefícios distribuídos e consomem metade do orçamento social consolidado brasileiro" (Néri, 2001, p.79).

Hoffmann (2002a) analisou a contribuição dos componentes do rendimento domiciliar para a desigualdade da distribuição do rendimento domiciliar per capita. Utilizando dados da PNAD de 1999, ele fez a decomposição do índice de Gini da distribuição do rendimento domiciliar per capita, considerando o rendimento do trabalho principal das pessoas ocupadas, rendimentos de outros trabalhos, aposentadorias e pensões, doações, aluguéis e uma parcela constituída por juros, dividendos e outros rendimentos, para o Brasil, Brasil metropolitano, Brasil urbano não-metropolitano e Brasil rural não-metropolitano. Para o Brasil, em 1999, os resultados mostram que os rendimentos do trabalho principal, que constituem $75,5 \%$ do rendimento total, dão origem à maior parcela do índice de Gini.

Ainda observa o citado autor que, entre os demais componentes do rendimento, as aposentadorias e pensões vêm a seguir, originando a segunda maior parcela do índice de Gini. Somente para áreas urbanas não-metropolitanas o efeito das aposentadorias e pensões no índice de Gini é neutro, porque a sua razão de concentração é quase idêntica ao índice de Gini. Para o Brasil rural não-metropolitano, observa-se que a razão de concentração de aposentadorias e pensões é ligeiramente superior ao índice de Gini, indicando que esse componente de rendimento tem contribuído para aumentar a desigualdade da renda rural. 
Hoffmann (2002a) conclui que, em geral, as aposentadorias e pensões contribuem substancialmente para aumentar a desigualdade da distribuição do rendimento domiciliar per capita para o ano de 1999.

Néri (2001) argumenta que as políticas sociais no Brasil não atingem os seus objetivos e são voltadas para as consequiências e não para as causas da miséria. É preciso entender por que existe pobreza no Brasil, por que as chances dadas aos pobres são remotas e na maioria das vezes não prosperam, por que pessoas pobres recebem menos.

Os argumentos e fatos, verificados pelos autores citados anteriormente, mostram que os gastos sociais no Brasil são ineficientes sob o ponto de vista de redistribuição e alcance aos grupos menos favorecidos e contribuem para a perpetuação da má distribuição de renda. Especificamente no caso das aposentadorias e pensões, as pesquisas mostram como tais benefícios são mal distribuídos e contribuem para aumentar a desigualdade de renda.

A próxima seção mostra alguns problemas que têm afetado a distribuição da renda de aposentadorias e pensões no Brasil.

\subsection{Critérios e requisitos do sistema previdenciário}

Os sistemas previdenciários, na maioria dos países, passaram por reformas e fazem constantes ajustes, para permanecerem dentro de um nível de racionalidade adequado e gerenciamento correto. Essas reformas e ajustes são necessários em função da dinâmica demográfica, das alterações do mercado de trabalho e de renda e de correções de distorções do sistema.

Stephanes (1999, p.4) estabelece a finalidade de um sistema previdenciário como segue: 
"Em regra, previdência está relacionada a seguro, formado este por um programa de pagamentos prestados ao indivíduo ou a seus dependentes, como compensação parcial ou total da perda de capacidade laborativa por doença, invalidez, morte (deixando a pensão protegendo a família) ou por idade avançada. Aos segurados, garantem-se os benefícios que, geralmente, guardam proporção com as contribuições. Assim, executa-se o princípio da eqüidade, mas existem outros que precisam ser cumpridos: o da universalidade, da solidariedade e da redistribuição".

A universalidade é a proteção social que deve atingir a todos, através da previdência social. A eqüidade no sistema previdenciário está relacionada ao financiamento do sistema, que é baseado no caráter contributivo do vínculo dos segurados e, ao mesmo tempo, a contribuição precisa ser estabelecida de acordo com a capacidade de cada indivíduo e a retribuição deve ser proporcional a essa mesma contribuição.

A solidariedade e a redistribuição estão relacionadas, porque o regime de repartição simples pode propiciar o surgimento de várias formas de subsídios entre as pessoas de uma mesma geração. Esta distribuição de renda intrageracional dependerá da carência exigida para a concessão do benefício, do limite de idade, do nível de reposição e da sistemática de cálculo do valor do benefício.

Para que os princípios citados anteriormente sejam atingidos, é necessário que os legisladores conduzam o sistema previdenciário com equilíbrio entre receitas e despesas. Porém, essa tarefa é muito difícil porque existem diversos grupos e segmentos da sociedade com interesses conflitantes e que buscam manter privilégios.

Em países onde os princípios básicos do sistema previdenciário são respeitados, o modelo de repartição simples funciona com as contribuições dos atuais trabalhadores, por um período de 35 a 40 anos, financiando as aposentadorias dos inativos, que, em média, recebem o benefício por 18 anos, enquanto as próximas gerações irão financiar os benefícios dos que estão contribuindo (Stephanes, 1999). 
Porém, no Brasil, o período médio de contribuições e a idade média de concessão de aposentadorias estão aquém da média mundial, ignorando conceitos e princípios do regime de repartição simples.

De acordo com Stephanes (1999, p.13),

“[...] em uma empresa estatal brasileira, a idade média da concessão de aposentadorias foi de 48 anos; isso numa classe de pessoas que têm uma expectativa de vida em torno de 80 anos, o que equivale dizer que embora tenham contribuído menos de 30 anos, em média, essas pessoas vão gozar uma aposentadoria durante 32 anos. Como as estatísticas demonstram que esse benefício gera uma pensão por mais oito anos, a média final pula para 40 anos".

O sistema de repartição simples generalizou-se após a Segunda Guerra Mundial e estabeleceu o chamado pacto entre gerações, condicionando os recursos arrecadados num determinado exercício ao pagamento dos benefícios durante este mesmo exercício. Quer dizer, o equilíbrio do sistema fica condicionado ao número de contribuintes, formados pelos trabalhadores na ativa, e o número de benefícios (os inativos).

Esse modelo é considerado um sistema fácil e barato de administrar, mas bastante vulnerável diante das mudanças demográficas. De acordo com Stephanes (1999), a conclusão é que a situação econômica dos trabalhadores e dos aposentados será atingida, se a situação econômica do país estiver mal.

Além disso, o envelhecimento populacional, o desemprego e a informalidade também colaboram para que o sistema de repartição simples não funcione a contento, pois o número de beneficiários, ou inativos, tende a crescer relativamente mais do que o de ativos. Esses fenômenos estão presentes no Brasil.

Outra restrição ao modelo de repartição simples, de acordo com Stephanes (1999), é a redistribuição invertida de renda, na qual aqueles que ganham menos estão financiando os que se aposentam mais cedo e que ganham mais. Além disso, os mais 
ricos têm o poder de influenciar decisões favoráveis às suas categorias, aposentando-se com menos idade, enquanto os trabalhadores com menos renda aposentam-se com mais idade. A base de cálculo do valor dos benefícios, que tem sido usada, são as remunerações dos últimos anos da vida profissional. Nesse caso, os que ganham melhores salários são mais favorecidos porque, em regra, atingiram essa posição ao final de suas carreiras ou estão prestes a se aposentar, enquanto aqueles que ganham menos, e em geral realizam tarefas que empregam mais força física e, conseqüentemente, têm declínio de renda nos últimos anos de carreira.

De acordo com os especialistas da área, para que o sistema previdenciário no Brasil funcione equilibradamente, além de uma boa administração e de um bom gerenciamento, diminuição de erros, fraudes, sonegação e custos operacionais, é necessária uma correção de problemas estruturais. A falta de equilíbrio entre os Regimes Previdenciários pode ser ilustrado com um exemplo. Em 1997, 17\% dos beneficiários da previdência faziam parte do Regime dos Servidores Públicos, englobando União, Estados e Municípios, e consumiram 53\% dos gastos com aposentadorias e pensões, enquanto os outros $83 \%$ eram provenientes do Regime Geral de Previdência Social e receberam 47\% dos gastos com aposentadorias e pensões (Médici, 1998).

Esse problema também é relatado em Stephanes (1999). Ele mostra que a falta de eqüidade e de justiça social são consideradas como um dos principais problemas estruturais. O sistema previdenciário, composto pelo Regime Geral de Previdência Social, administrado pelo INSS, concentra $86 \%$ da população previdenciária. No Regime dos Servidores Públicos, englobando União, estados, municípios e poderes executivo, legislativo e judiciário, encontram-se os outros 14\%. Porém, os 14\% consomem mais do que os $86 \%$ que estão no INSS. Em países com regimes semelhantes ao do Brasil, esses gastos não ultrapassam um terço, assim como também o número de funcionários públicos aposentados não ultrapassa um terço dos funcionários públicos ativos. 
Outro aspecto importante, que revela a desigualdade entre os regimes, são as regras para obtenção de benefícios. A aposentadoria por tempo de serviço, que no Brasil tornou-se uma maneira de garantir aposentadorias precoces para os segmentos de mais alto poder aquisitivo, é perversa, pois trabalhadores de baixa renda, normalmente, têm dificuldades de inserção no mercado de trabalho e permanecem períodos longos na informalidade, o que impede a comprovação do tempo de contribuição junto ao INSS.

De acordo com Stephanes (1999), no regime do INSS, em 1997, 17\% dos benefícios foram por tempo de serviço, representando 39\% da despesa previdenciária. Desses, dois terços se aposentaram com menos de 54 anos de idade e são de pessoas que possuem melhor qualidade de vida, melhores condições sociais e maior expectativa de vida. $\mathrm{O}$ referido autor ainda verifica que quem recebe menos está financiando a aposentadoria dos que ganham mais. Enquanto uma distribuição de renda perversa ocorre entre os segurados do INSS, no setor público, quem paga a conta, inclusive de determinados grupos e categorias que obtêm privilégios, é a sociedade como um todo.

Stephanes (1999) mostra que o Regime do Servidor Público Civil Federal tornou mais vantajoso estar aposentado. Em algumas categorias de determinados regimes, já existe um número de inativos bem superior ao de ativos, demonstrando que há uma predominância de aposentadorias precoces, com freqüentes casos de pessoas que se aposentam com menos de 40 anos de idade. Existem leis especiais que chegam a permitir que o servidor se aposente a partir dos 37 anos de idade. São pessoas cuja qualidade de vida proporciona-lhes uma expectativa de atingir 80 anos de idade. Outras categorias têm idade média da aposentadoria de 48 anos, com expectativa de ficarem aposentados durante 32 anos, adicionando ainda um período em torno de oito anos referentes à pensão dos dependentes. Nesses casos, uma contribuição de 25 anos, em média, dá direito a um benefício de 40 anos entre aposentadoria e pensão. 
A legislação permitia, até 1996, que contassem tempos não contribuídos e licenças-prêmio em dobro. Valiam também tempo de colégio militar obrigatório, férias em dobro e licença para tratamento de familiar doente. Como esses servidores aposentam com pouca idade, a maioria vai trabalhar no setor privado ou volta a ocupar cargos públicos. Além disso, estados e municípios podem ter introduzido uma série de critérios desconhecidos da maioria da população, permitindo que alguns poucos servidores se aposentassem precocemente.

Outra distorção é a possibilidade de o servidor público, mesmo que recémingressado, requerer a aposentadoria utilizando o tempo de serviço anterior, inclusive o tempo rural, que quase sempre é não-contributivo, ficando, dessa forma, dispensado de carência ou prazo de permanência no cargo ou função.

Os valores pagos de aposentadorias e de pensões também são uma mostra da desigualdade entre os regimes. No INSS, o valor médio do benefício rural é de um salário mínimo e o médio urbano, de 2,1 salários mínimos por mês. Muitos dos benefícios dos servidores do poder legislativo e do poder judiciário são baseados em condições que propiciam alcançar, por exemplo, o valor médio de 36,2 salários mínimos por mês. Isso corresponde ao que a maioria dos segurados do INSS vão ganhar em três anos. Apesar disso, $80 \%$ dos servidores públicos brasileiros se aposentam com rendimentos de até $\mathrm{R} \$ 1,2$ mil, em valores de 1998 (Stephanes, 1999).

A diferença dos valores de benefícios entre servidores e o INSS pode, também, ser explicado pelo fato de que os aposentados do serviço público brasileiro podem receber adicionais ao salário da ativa, através de artifícios que estão embutidos nas leis da união, dos estados e dos municípios. Para os servidores do poder executivo, os valores dos benefícios podem chegar até a $12 \%$ a mais em relação aos salários da ativa, enquanto no legislativo e judiciário existem categorias que recebem benefícios com valores superiores até $50 \%$ aos valores dos ativos. Dessa forma, existem servidores que, 
por meio desses critérios especiais ou aproveitando dos lapsos legais, chegam a receber benefícios de 50 a 200 salários mínimos (Stephanes, 1999).

Outro problema é o acúmulo de remunerações. É comum o servidor, civil ou militar, aposentar-se no serviço público por tempo de serviço, ingressar no regime INSS e obter aposentadoria por idade. Se o servidor civil exercia atividade concomitante, coberta pelo mesmo regime, ou por outro, também pode receber outra aposentadoria, por tempo de serviço, ou por idade.

Os regimes INSS e do serviço público não aceitam a acumulação de aposentadorias nos próprios regimes, mas permitem com os demais. Os regimes permitiram acumulações internas de uma ou mais pensões e destas com aposentadorias, sem qualquer critério de seletividade (Stephanes, 1999).

No Brasil, o poder legislativo tem competência para estabelecer regras e normas próprias do sistema previdenciário. Isso levou à produção de critérios envolvendo determinadas categorias, que podem ter menor tempo para aposentar, ou podem utilizar contagem fictícia em determinadas situações; além de casos especiais que permitem fórmulas de cálculos diferenciados para aposentadorias, sem falar em muitos erros e distorções surgidos de leis mal redigidas.

Os Regimes Complementares, que foram criados como instrumentos de equilíbrio e desenvolvimento social, também apresentaram problemas. Nesses regimes, projetados em cenários otimistas, ou não aconteceram os ajustes necessários com o passar do tempo, ou tiveram seus recursos administrados inadequadamente, além de ter precocidade das aposentadorias, o que levou algumas estatais brasileiras a terem insuficiência de capitalização. Para ajustar um plano com insuficiência de capitalização, medidas combinadas de aumento da contribuição da patrocinadora e dos participantes e redução dos benefícios oferecidos devem ser adotados. Porém, a maioria das empresas 
estatais já efetua contribuições elevadas para os seus fundos de pensão, chegando a casos que superam $20 \%$ da folha de salários da empresa.

A conseqüência dessas aposentadorias precoces é que toda a sociedade paga a conta. Pessoas que se aposentam antes dos 50 anos de idade, dependendo do sexo, em função do tempo de contribuição, terão benefícios subsidiados entre 40 e $60 \%$ do valor (Stephanes, 1999).

Com relação aos altos valores dos benefícios, pode-se dizer que eles ocorrem porque não existia um teto para os mesmos, com exceção do INSS. Embora a Constituição estabeleça um limite de salários, nunca houve entendimento sobre o assunto pelos legisladores e o próprio judiciário. A grande maioria dos países limita o valor máximo da aposentadoria paga pelo sistema previdenciário público, o que não acontece no Brasil.

O valor do benefício que o trabalhador recebe é sempre inferior ao seu último salário. Stephanes (1999) mostra alguns exemplos desse limite. Na Inglaterra, em 1993, o valor máximo da aposentadoria por idade foi em torno de US\$2.455 mensais e tendo como obrigatoriedade a aposentadoria complementar. $\mathrm{O}$ valor das aposentadorias passou a ser calculado pela média dos salários ganhos durante a vida ativa do trabalhador e não mais pelos vinte melhores anos.

Nos Estados Unidos, os valores dos benefícios são calculados a partir do ganho médio real do segurado durante toda sua vida ativa, sobre o qual incide uma alíquota variável. Os trabalhadores de renda baixa, média e alta se aposentam com, respectivamente, cerca de $60 \%, 45 \%$ e $25 \%$ do rendimento correspondente aos ativos. A partir de 2003, a idade mínima para obter aposentadoria naquele país passou para 67 anos.

Na Alemanha, o valor máximo da aposentadoria é de US\$ 4.554 por mês, além de o Estado garantir uma renda mínima de US\$ 333 por mês. 
$\mathrm{Na}$ França, o sistema estatal dispõe de uma aposentadoria básica e uma complementar, mas ambas são compulsórias e elas asseguram, em média, 80\% das remunerações da atividade.

No Japão, o valor máximo da aposentadoria, em 1993, era de US\$ 4.230. Na Espanha, o teto é de US\$ 2.300 por mês. Na Itália, o valor pode chegar a $80 \%$ da renda para aqueles que contribuíram para o sistema durante quarenta anos.

No Chile, o valor do benefício depende da opção escolhida pelo segurado junto à administração do fundo de pensão e do valor das contribuições que realizou. Se o contribuinte alcançar a idade fixada e tiver contribuído por, pelo menos, vinte anos, o governo chileno garante a esse cidadão uma aposentadoria mínima.

No Uruguai, o teto do benefício no sistema público e do sistema básico é de cerca de US\$ 650 por mês. Os trabalhadores uruguaios são obrigados a participar de um sistema complementar que funciona sob regime de capitalização, e o benefício máximo é de cerca de US\$ 1.650 por mês.

Dessa maneira, observa-se que o sistema previdenciário no Brasil apresenta privilégios e distorções pela falta de uniformidade de critérios e requisitos dos regimes de previdência, fugindo dos conceitos e fundamentos básicos que compõem a doutrina do sistema previdenciário, contribuindo para aumentar as diferenças no valor dos benefícios dos trabalhadores.

Esses problemas foram ganhando maior importância à medida que alguns fatores como: mudanças demográficas, composição do mercado de trabalho e a Constituição de 1988 contribuíram para a impossibilidade de sustentação do sistema de previdência social no Brasil. Esses fatores têm o poder de determinar o futuro da previdência e são comentados nas próximas seções. 


\subsection{Mudanças demográficas}

À medida que as conjunturas se modificam, surge a necessidade de interferir no sistema com pequenos ajustes ou mudanças maiores. As mais comuns ocorreram em função das alterações demográficas: as pessoas passaram a viver mais tempo. Em consequiência, em termos populacionais, aumentou o número de idosos e simultaneamente a base da pirâmide não tem crescido, devido à diminuição da natalidade. $\mathrm{O}$ envelhecimento da população brasileira é um fenômeno que já está ocorrendo e tende a crescer nas próximas duas décadas. Basta observar a tendência de declínio da taxa de crescimento da população. De acordo com Brant (2001a), a taxa média anual de crescimento da população, que diminui de 3,0\% na década de 60 para 1,4\% na década de 90, deverá manter a tendência de queda nos próximos 20 anos, chegando a $1,0 \%$ entre 2010 e 2020.

Demograficamente, a população mundial e, em especial, a brasileira, tem apresentado baixas taxas de fecundidade, aumento da longevidade e urbanização acelerada. Essa interação tem levado a um maior crescimento da população idosa em relação aos demais grupos etários. A pesquisa de Camarano (2002) mostra que a participação da população maior de 60 anos na população brasileira mais que dobrou no último meio século, passando de 4\%, em 1940, para 8\%, em 1996. A autora estima que em 2001, a população brasileira com mais de 60 anos seria da ordem de 15 milhões de habitantes, e que, em 2020, aproximadamente $15 \%$ da população será composta por idosos. 
Esse cenário é visto pelos estudiosos do assunto com preocupação, por demandar mudanças no perfil das políticas públicas, colocando novos desafios para o Estado, a sociedade e a família. A transferência de recursos na sociedade é um deles. Por exemplo, as demandas de saúde, implicando em maior freqüência de internações hospitalares, consultas ambulatoriais, remédios etc, aumento da demanda sobre o sistema previdenciário, através de aposentadorias e pensões, adicionando-se ainda que o envelhecimento requer também cuidados e atenção especial da família.

Com relação à fonte de rendimentos, Camarano et al. (1999) mostram que a maior parte da renda dos idosos em 1997 provém de aposentadorias, principalmente dos idosos homens, e essa importância cresce com a idade. O trabalho contribui com aproximadamente $55 \%$ da renda dos que tinham de 60 a 64 anos e $15 \%$ dos rendimentos da população maior de 80 anos. A diminuição da importância da renda do trabalho é compensada principalmente pela renda da aposentadoria. A importância de outras rendas também cresce com a idade, mas não ultrapassa 13\% entre os maiores de 80 anos, enquanto para esse mesmo grupo etário a contribuição da aposentadoria foi de $72 \%$. Para as mulheres, a importância das aposentadorias é menor, mas, em compensação, aumenta a importância das pensões. Em conjunto, aposentadorias e pensões representam $67 \%$ da renda para as mulheres entre 60 e 64 anos e $78 \%$ da renda daquelas que tinham mais de 80 anos. A contribuição da renda do trabalho entre as mulheres de 60 a 64 anos foi de $22 \%$, entre as de 65 a 69 anos foi de $11 \%$, e entre as de 80 anos e mais, de $2 \%$.

De acordo com Pinheiro (2002), na área urbana, em média, 63,9\% da renda dos idosos homens e 79,3\% da renda das mulheres são transferências previdenciárias, sendo que para elas as pensões representam 34,9\% de seus rendimentos. $\mathrm{Na}$ área rural, 87,4\% da renda das mulheres idosas são provenientes da previdência.

Pinheiro (2002) mostra que são os idosos que elevam a renda de suas famílias. Nas famílias em que eles são os chefes, são responsáveis por cerca de 75,2\% da renda 
total. Nas áreas rurais, esse percentual é ainda mais elevado, respondendo por $81,7 \%$ da renda familiar. Constata-se que, tanto na área urbana como rural, a participação da renda do idoso é de grande importância para a renda familiar.

No setor rural, a partir de 1992 com a ampliação das novas leis de custeio e benefício da previdência, o meio rural passa a ter efetivamente acesso à previdência rural, atendendo ao trabalhador informal e à agricultura de subsistência. De acordo com Delgado \& Cardoso Junior (1999), os principais resultados obtidos com a implantação da previdência no meio rural são: a) aumento expressivo da taxa de cobertura dos idosos rurais; b) inclusão expressiva das mulheres rurais no sistema de proteção social e c) elevação significativa da renda domiciliar do público beneficiário, incidindo tais benefícios sobre uma população rural ou microurbana, em geral, muito pobre.

Esses benefícios revitalizaram a economia familiar rural, constituindo, no meio rural, uma categoria social de aposentados como grupo social que se diferencia do universo de domicílios do setor rural tradicional. Essa diferenciação está centrada principalmente em novas estratégias de subsistência e de produção familiar, criando alternativas para gerar renda na agricultura.

Para Camarano et al. (1999), os idosos têm contribuído com uma parcela importante na renda das famílias da qual participam. Ela mostra, por exemplo, que no segmento masculino de 60 a 64 anos, a contribuição da renda do trabalho principal do idoso na renda da família estava em torno de $33 \%$ e a de todas as fontes, $64 \%$. Com o aumento da idade (acima de 64 anos) essa participação diminui, mas é em parte compensada ou atenuada pelo aumento de pensões e benefícios previdenciários.

Pesquisa realizada por Wajnman et al. (1999) mostra que a participação relativa dos rendimentos dos idosos na composição de sua renda familiar é muito importante. No grupo de 60 - 64 anos, no qual está presente o maior grupo de idosos ativos, o rendimento dos homens corresponde a $65 \%$ de sua renda familiar, da qual $36 \%$ são 
rendimentos do trabalho do idoso. À medida que vão envelhecendo, não diminui sua participação relativa na renda familiar, o que se verifica é uma mudança de composição segundo as fontes, em que as aposentadorias passam a ter grande importância.

A pesquisa realizada por Barros et al. (1999) revela que, aos 70 anos de idade, as rendas do trabalho representam pouco mais de $40 \%$ do ganho domiciliar per capita das pessoas, e a aposentadoria passa a representar mais de $50 \%$.

Camarano (2002) mostra que, entre 1981 e 1998, os rendimentos dos idosos melhoraram. Em 1981, $21 \%$ dos idosos não tinham nenhuma renda, ao passo que em 1998 esse percentual diminuiu para 12\%, devido, principalmente, ao aumento das mulheres que passaram a obter algum rendimento.

Essa melhoria não foi linear ao longo desse período. Houve uma piora entre 1981 e 1987 e depois a tendência foi de melhora. Segundo a pesquisadora, isso é resultado da universalização da seguridade social, da ampliação da cobertura da previdência rural e da legislação da assistência social estabelecidas pela Constituição de 1988, que garante aos idosos maiores de 67 anos um salário mínimo mensal, desde que comprovem condições de miséria, ou seja, renda per capita domiciliar abaixo de 1/4 do salário mínimo. De acordo com a pesquisadora, a renda do idoso depende, principalmente, dos benefícios previdenciários, que têm crescido ao longo do tempo, enquanto a sua participação no rendimento do trabalho não se alterou muito no tempo.

Barros et al. (1999) investigaram a posição dos idosos na distribuição de renda e comparam a distribuição da renda entre idosos, não-idosos e na população como um todo. Verificaram que a proporção de idosos é maior nos décimos de renda superiores, porque a probabilidade de uma pessoa viver mais aumenta com uma renda maior.

A pesquisa mostra que a evolução do percentual de idosos ao longo dos centésimos da distribuição da renda e a percentagem de idosos com 60 anos e mais 
ficam entre $2 \%$ e $4 \%$ na extremidade inferior da distribuição de renda, mas atinge mais de $10 \%$ na extremidade superior, ou seja, esse percentual é mais de três vezes superior para os extremamente ricos. Para os idosos com 70 anos e mais, esse resultado não é tão evidente, mas percebe-se que eles tendem a ser menos pobres do que a população como um todo.

Outro resultado interessante obtido na pesquisa de Barros et al. (1999) é a acentuada concentração de idosos no sexto e sétimo décimos da distribuição, assinalando que esta concentração deve-se ao vínculo das aposentadorias ao valor do salário mínimo. De acordo com IPEA (1997), em dezembro de 1995, cerca de $70 \%$ dos benefícios tinham valor igual ao salário mínimo.

A pesquisa de Barros et al. (1999) examinou também as diferenças na distribuição de renda entre idosos e não-idosos e na população total, com base nos dados da PNAD de 1997, e os seus resultados podem ser vistos na Tabela 3. Os valores do índice $\mathrm{T}$ de Theil são maiores entre os idosos $(0,76)$ do que entre não-idosos $(0,71)$, mostrando assim que a distribuição de renda entre os idosos é ainda mais desigual do que entre os não-idosos. O índice de Gini não apresentou distinção significativa entre idosos $(0,59)$ e não-idosos $(0,60)$.

Barros et al. (1999) construíram curvas de Lorenz com os dados de 1997 para a população: total, dos idosos e não-idosos. Pôde-se notar que as curvas de Lorenz para a população de idosos são sensivelmente diferentes das curvas para não-idosos e para a população total. Na comparação dos $60 \%$ mais pobres de cada distribuição, verifica-se que a renda encontra-se melhor distribuída entre os idosos do que entre os não-idosos ou na população total. Entre os $30 \%$ mais ricos, a situação se inverte e a renda é mal distribuída entre os idosos, indicando que a provável piora na distribuição de renda entre os idosos tem origem nos rendimentos da metade mais rica desta população. 
Na Tabela 3, observa-se que os $40 \%$ de idosos pobres detém 9,55\% da renda total dos idosos, ao passo que aos $40 \%$ de não-idosos pobres cabem somente $7,95 \%$ da renda total dos não-idosos. Constata-se, ainda, que a renda média é maior para idosos em todos os centésimos, perante o restante da população.

Tabela 3. Curva de Lorenz e índices de desigualdade - Brasil 1997

\begin{tabular}{|c|c|c|c|c|c|c|}
\hline \multirow{2}{*}{$\begin{array}{l}\text { Percentual da } \\
\text { população } \\
\text { (décimos) }\end{array}$} & \multicolumn{6}{|c|}{ Percentual acumulado da renda conforme grupos de idade } \\
\hline & Total & $\begin{array}{c}25 \text { A } 59 \\
\text { ANOS }\end{array}$ & $\begin{array}{l}60 \text { ANOS E } \\
\text { MAIS }\end{array}$ & $\begin{array}{l}65 \text { ANOS E } \\
\text { MAIS }\end{array}$ & $\begin{array}{l}70 \text { ANOS E } \\
\text { MAIS }\end{array}$ & $\begin{array}{l}75 \text { ANOS E } \\
\text { MAIS }\end{array}$ \\
\hline 1 & 0,66 & 0,66 & 1,10 & 1,19 & 1,24 & 1,27 \\
\hline 2 & 2,23 & 2,25 & 3,09 & 3,23 & 3,31 & 3,36 \\
\hline 3 & 4,59 & 4,64 & 5,91 & 6,13 & 6,27 & 6,33 \\
\hline 4 & 7,84 & 7,95 & 9,55 & 9,83 & 10,00 & 10,15 \\
\hline 5 & 12,21 & 12,32 & 13,52 & 13,72 & 13,81 & 14,00 \\
\hline 6 & 17,84 & 18,10 & 18,68 & 18,72 & 18,63 & 18,60 \\
\hline 7 & 25,43 & 25,80 & 25,59 & 25,48 & 25,19 & 24,90 \\
\hline 8 & 36,04 & 36,52 & 35,31 & 35,06 & 34,65 & 34,21 \\
\hline 9 & 52,52 & 53,17 & 50,81 & 50,58 & 50,01 & 49,58 \\
\hline 10 & 100,00 & 100,00 & 100,00 & 100,00 & 100,00 & 100,00 \\
\hline $\begin{array}{l}\text { Renda média } \\
\text { (R\$ de 1997) }\end{array}$ & 243,83 & 294,87 & 324,32 & 322,15 & 320,62 & 312,31 \\
\hline $\begin{array}{c}\text { Índice } \mathrm{T} \text { de } \\
\text { Theil }\end{array}$ & 0,73 & 0,71 & 0,76 & 0,75 & 0,77 & 1,00 \\
\hline $\begin{array}{l}\text { Coeficiente de } \\
\text { Gini }\end{array}$ & 0,60 & 0,60 & 0,59 & 0,59 & 0,60 & 0,76 \\
\hline
\end{tabular}

Fonte: Barros et al. (1999) 
A posição dos idosos na distribuição de renda também foi investigada por Barros et al. (2000) com dados da PNAD de 1983, 1988, 1993 e 1998. Os resultados obtidos foram iguais aos descritos anteriormente pelos mesmos autores. Destaca que, comparativamente, a década de noventa foi mais favorável aos idosos do que a década de oitenta.

Portanto, verifica-se que as aposentadorias e pensões são importantíssimas para os idosos, porque um significativo percentual da renda familiar tem origem na renda dos idosos e grande parte desta provém desses benefícios. Observa-se que a distribuição de renda entre os idosos é desigual, e que o direcionamento de uma política previdenciária focada na distribuição desses rendimentos para os mais pobres é de fundamental importância.

De acordo com Stephanes (1999), os impactos da dinâmica demográfica com respeito à previdência social refletem-se tanto nas despesas com benefícios quanto no lado das receitas. Para manter o equilíbrio no sistema de repartição simples, o elemento fundamental, considerando-se somente as variáveis demográficas, é a estrutura etária da população em cada momento, pois é ela que define a relação entre beneficiários (população idosa) e contribuintes (população em idade ativa).

No Brasil, de acordo com Cechim (2002), a esperança de vida passou de cerca de 40 anos, na década de 40, para 68 anos em 2000. As perspectivas são de crescimento contínuo, pela influência da maior esperança de vida observada nos países mais ricos e pelas diminuição acentuada da mortalidade infantil.

O peso das esperanças de vida nas idades de aposentadoria (expectativa de sobrevida) é muito importante para os sistemas previdenciários porque define o período médio de duração das aposentadorias. De acordo com Cechin (2002), nas décadas de 30 e 40, a expectativa de sobrevida para uma pessoa de 40 anos era de 24 anos para homens 
e de 26 anos para mulheres. Já em 2000, ela subiu para 31 e 37 anos para homens e mulheres, respectivamente. No caso de uma pessoa de 60 anos, a expectativa de sobrevida aumentou de 13 anos para homens e 14 anos para mulheres na década de 30, para 16 e 20 anos em 2000.

As pirâmides populacionais brasileiras mostram significativas modificações na estrutura etária, com o progressivo incremento da população com mais de 60 anos. De acordo com as projeções de Cechim (2002), observa-se o estreitamento gradual da base da pirâmide demográfica e o alargamento do seu topo entre 1980 e 2001, refletindo os efeitos da queda da proporção da população jovem em relação ao total e o aumento gradativo da população com idade avançada.

A idade média das aposentadorias por tempo de contribuição atualmente é de 54 anos e a duração média de uma aposentadoria no Brasil supera 20 anos, maior do que a observada nos países desenvolvidos, de 18 anos (Cechin, 2002).

A sustentabilidade da previdência social exige novas reformas que levem em conta essa tendência de vidas mais longas. Dessa forma, ajustes como o alongamento do período de trabalho e de contribuição são necessários, criando novos estímulos para que a aposentadoria ocorra em idades mais altas.

\subsection{Mudanças na composição do mercado de trabalho}

O mercado de trabalho formal tem apresentado queda nos últimos anos, e essas mudanças estão intimamente relacionadas com a previdência social. De acordo com Najberg \& Ikeda (1999), observa-se uma tendência de redução da participação de salários no valor total de produção, especialmente no setor industrial, no qual tal participação é mais expressiva no mercado formal. $\mathrm{O}$ setor industrial tem perdido posição em favor do setor de comércio e de serviços, que emprega cada vez mais trabalhadores, mas com elevado grau de informalização. Além disso, constata-se uma 
tendência de remunerar o trabalhador formal com menor salário fixo e com participação nos lucros através de gratificação, bônus ou dividendos, sem que haja incidência de contribuição tanto do empregado quanto do empregador. Essas novas tendências contribuem bastante para diminuir a arrecadação da previdência social.

Segundo Stephanes (1999), a relação de contribuintes ativos por beneficiário na década de 1950 era de oito, enquanto para as décadas de 1970 e 1980 essa relação foi de 4,2 e 3,2 respectivamente. De acordo com dados de Ornélas (2002), essa mesma relação caiu de 2,4 em 1991 para 1,7 em 1997, chegando a 1,3 em 2001. Essa queda implicou em sucessivos aumentos das alíquotas de contribuição, redução no valor real dos benefícios e utilização de receita de impostos para cobrir o déficit da previdência. $\mathrm{Na}$ União Européia, de acordo com Ornélas \& Vieira (2002), existem em média quatro trabalhadores para cada aposentado, mas em 2040 serão apenas dois trabalhadores por aposentado e na Alemanha, por exemplo, esta relação estará próxima de um para um em 2040.

Ornélas \& Vieira (2002) destacam que a base de contribuintes da previdência no Brasil esteve sempre abaixo do seu potencial. Em 1997, cerca de $62 \%$ da população ocupada não contribuía para o Regime Geral de Previdência Social (RGPS) e 56\% dela não contribuía para nenhum tipo de previdência. $\mathrm{O}$ alto grau de emprego informal, as tecnologias poupadoras de mão-de-obra e a crescente taxa de evasão das contribuições sociais no mercado formal fazem reduzir sensivelmente as fontes de recursos dos benefícios. Esses dados mostram a importância do mercado informal no país e a necessidade de uma revisão na estrutura tributária e na legislação trabalhista, de maneira que aumentem os incentivos para a sua regularização.

De acordo com Cechin (2002), na última década houve uma grande mudança na estrutura de mercado de trabalho, resultando em flexibilização das relações de trabalho, a partir da reestruturação produtiva das empresas, principalmente pela evolução tecnológica, e pelas modificações na legislação trabalhista e tributária. Esse processo 
resultou no aumento da participação de cooperativas de trabalho e terceirização de mão-de-obra.

Essas mudanças afetaram a previdência social e foram compensadas por meio de aumento de alíquotas, elevando o custo do trabalho para empregadores, estimulando ainda mais a substituição de contratos com registros por novos empregados sem carteira assinada, contribuindo para elevar o grau de informalidade no mercado de trabalho.

A Tabela 4 mostra a evolução do mercado de trabalho no Brasil, indicando claramente o avanço do trabalho informal. Em 1982, os trabalhadores com carteira assinada representavam 57\% do total da população ocupada, chegando em 1990 com o mesmo nível, reduzindo-se este acentuadamente a partir do início dos anos 90.

Ornélas (2002) argumenta que os regimes de previdência tradicionais, baseados no mecanismo de repartição simples, mesmo os que adotaram princípios rígidos de doutrina de seguro social, essencialmente contributivos e com aposentadorias exclusivamente por perda de capacidade laborativa, porém ancorados no mercado formal, vêm apresentando sinais de exaustão quanto ao financiamento do elenco de benefícios. Isso se deve, basicamente, às mudanças no mercado de trabalho, cada vez mais não-formal, além da crescente longevidade da população.

Pinheiro (2002) mostra que desde o início da organização do sistema previdenciário a alíquota paga pelas empresas aumentou de 3,5\%, em 1938, para os atuais $20 \%$ incidentes sobre o total da folha de salários. Esta elevação de alíquotas ocorreu em meio a um processo de desenvolvimento por substituição de importações, com uma economia fechada, organizada em estruturas oligopolísticas, em que os custos do aumento do preço da mão-de-obra foram repassados para os preços das mercadorias e pagos por toda a sociedade. Com a abertura da economia, essas alíquotas representam empecilhos ao aumento da competitividade das empresas. Além disso, as altas taxas de 
contribuição condicionaram aumento de informalidade, da evasão e diminuição da cobertura de benefícios.

Tabela 4. Média anual da participação dos trabalhadores com carteira assinada na população ocupada - Brasil, de 1982 a 1999

\begin{tabular}{lc}
\hline Ano & \% de trabalhadores com carteira assinada \\
\hline 1982 & 57 \\
1983 & 56 \\
1984 & 54 \\
1985 & 56 \\
1986 & 58 \\
1987 & 58 \\
1988 & 58 \\
1989 & 59 \\
1990 & 57 \\
1991 & 54 \\
1992 & 52 \\
1993 & 51 \\
1994 & 49 \\
1995 & 48 \\
1996 & 47 \\
1997 & 46 \\
1998 & 46 \\
1999 & 45 \\
\hline
\end{tabular}

Fonte: Ornélas \& Vieira (2002) 
É preciso considerar também, como destacam Najberg \& Ikeda (1999), que a participação das mulheres no mercado de trabalho vem aumentando. Destaca-se que as mulheres necessitam de cinco anos a menos de tempo de serviço para atingir os critérios mínimos de obtenção de suas aposentadorias. Sabe-se também que a expectativa de sobrevida das mulheres é superior à dos homens. Assim, o déficit atuarial é maior nas aposentadorias das mulheres do que nas dos homens.

\subsection{Mudanças na Constituição de 1988}

A Constituição de 1988 teve um grande impacto no Regime Geral de Previdência Social e no Regime dos Servidores Públicos.

No Regime Geral, aumentaram os gastos previdenciários sem contrapartida suficiente de receita. De acordo com a Constituição de 1988, nenhuma aposentadoria ou pensão poderá ser inferior a um salário mínimo. Além disso, tanto homens como mulheres poderão se aposentar proporcionalmente; aqueles aos 30 anos de serviço e estas aos 25 anos. Para os funcionários públicos, os reajustes das aposentadorias serão feitas na mesma época e com os mesmos índices obtidos pelos trabalhadores da ativa. Os trabalhadores rurais se aposentam aos 60 anos de idade e as trabalhadoras, aos 55 anos.

O cálculo dos futuros benefícios será baseado nos últimos 36 salários de contribuição, corrigidos monetariamente.

Com a aprovação da Constituição de 1988 aumentou expressivamente a quantidade de benefícios e o seu valor médio, principalmente para os benefícios rurais, que passaram de meio para um salário mínimo. De acordo com Delgado \& Cardoso (2002), a previdência rural pagou, em 1998, 6,91 milhões de aposentadorias, pensões, rendas mensais vitalícias e amparos previdenciários aos seus segurados. Conforme Brant (2001a), entre 1988 e 2000, o número de benefícios pagos pelo sistema aumentou 71,6\%, passando de 11,6 milhões em 1988 para 19,9 milhões em 2000. O aumento da quantidade e do valor médio dos benefícios fez com que a despesa com benefícios pagos pela previdência mais do que duplicasse, passando de 2,6\% do PIB em 1988 para 6,1\% em 2000. De Acordo com Stephanes (1999), se não houver nenhuma reforma, a projeção de evolução da despesa com 
benefícios, em percentual do PIB, será de aproximadamente 8\% do PIB em 2014 e $10 \%$ do PIB em 2025.

Comparativamente com os dados anteriores, Ornélas \& Vieira (1999), citando Budd \& Campbell (1998), afirmam que o aumento esperado para os gastos previdenciários no Reino Unido é de 4,6\% do PIB até 2050, enquanto para os Estados Unidos, Japão e França a previsão é de algo entre $26 \%$ e $100 \%$ do PIB, uma projeção obviamente irrealizável. No Brasil, os déficits constantes da previdência a partir de 1995 enfatizaram a necessidade de reforma. De acordo com Cechin (2002), a necessidade de financiamento da previdência social no período 2002 a 2021 levará a um déficit de 2,2\% do PIB.

No Regime dos Servidores públicos, o impacto das mudanças na Constituição de 1988 foi considerável, envolvendo o funcionalismo público federal, estadual e municipal. Em muitos casos, provocaram problemas econômicos e financeiros para essas esferas de governo.

Houve incentivos para estados e municípios instituírem seus próprios regimes, transformando seus funcionários de celetistas em estatutários. Com isso, estados e municípios se beneficiaram com: a) não-contribuição para o INSS e para o FGTS, reduzindo o gasto com a folha de pagamento em torno de $30 \%$, b) a disponibilidade adicional de recursos provenientes das contribuições dos servidores públicos, c) a compensação financeira entre regimes previdenciários.

"A perspectiva de melhora imediata na situação financeira dos tesouros locais fez com que uma série de estados e municípios criassem seus "regimes únicos", sem a preocupação de que, no médio e longo prazos, haveria o custo de arcar com a aposentadoria desses trabalhadores. Na maioria dos casos, a ausência de estudos atuariais levou ao estabelecimento de alíquotas de contribuição em percentuais inferiores aos que seriam adequados. Além da redução na alíquota de contribuição, o ingresso no regime jurídico único permitiu aos 
servidores com remuneração alta uma aposentadoria maior do que o teto assegurado pelo regime geral. Os dados indicam que, atualmente, para a grande maioria dos estadose municípios, mais de $40 \%$ da folha de pagamentos seriam constituídos apenas por aposentados" (Najberg \& Ikeda, 1999, p.270).

Constata-se que as mudanças na Constituição de 1988 referentes à previdência social representaram grande conquista social para alguns setores, embora a contrapartida financeira tenha sido distribuída por toda a sociedade. $\mathrm{O}$ problema fundamental das mudanças consistiu na concessão de benefícios sem a exigência de contribuição suficiente para cobrir os gastos. O resultado foi o crescimento das despesas e a elevação do déficit previdenciário.

\subsection{Reforma da previdência - Emenda Constitucional $n^{0} 20$}

A reforma ou o ajuste do sistema previdenciário fez-se necessário por diversas razões, entre as quais destacam-se: a elevação do déficit previdenciário, a concessão de privilégios e grandes distorções nos regimes de previdência e a introdução de conceitos e fundamentos básicos que compõem a doutrina universal, reestruturando-a para o futuro.

No entanto, sabe-se que é extremamente difícil implementar um sistema de previdência com regras universais e compatíveis com os princípios atuariais, face às reações dos segmentos protegidos, que se utilizarão de todos os meios para manter a situação de privilégio em que se encontram.

Mas, a partir da década de 1990, com projeções que apontavam para a total inviabilidade dos regimes de previdência no Brasil, a sua reforma tornourse inevitável.

Com a estabilidade monetária, tornando as contas públicas transparentes, pôde-se perceber com clareza os problemas do sistema previdenciário ${ }^{11}$.

\footnotetext{
${ }^{11}$ Para maiores detalhes ver Cechin (2002, p.14).
} 
Frente a um quadro desfavorável, o governo propôs algumas medidas que visassem à redução das distorções existentes no sistema previdenciário, procurando também buscar o equilíbrio de suas contas.

Os aspectos propostos pelo governo 12 ao legislativo, para a reforma, de acordo com Brant (2001b), foram:

A - desconstitucionalização das regras previdenciárias;

B - extensão das regras do Regime Geral dos trabalhadores assabriados (cálculo, reajuste e valor-teto) aos servidores públicos, exceto para os militares federais;

C - para os servidores ainda em atividade, mantinha a integralidade da remuneração na aposentadoria, obedecido um valor-teto e com reajuste que preservasse o valor real do benefício;

D - extinção da aposentadoria proporcional por tempo de serviço; e

E - extinção da aposentadoria especial do professor.

Após quatro anos de discussões aprovou-se a Emenda Constitucional $\mathrm{n}^{\mathrm{o}}$ 20, em dezembro de $1998^{13}$. Para Stepha nes (1999) e Brant (2001a), a Emenda Constitucional que modifica o sistema de previdência social representou um avanço, embora aquém das necessidades de ajuste dos regimes de previdência, e prevêem que dentro de mais alguns anos ela terá que ser revista.

As principais modificações que merecem destaque são:

A - A mudança no texto constitucional de "anos de serviço" para "anos de contribuiçãao", como critério de concessão por tempo de serviço;

B - A extinção da aposentadoria proporcional por tempo de serviço;

C - A mudança da regra de cálculo do valor dos benefícios;

D - O fim da aposentadoria especial para professores universitários e aeronautas, entre outros;

\footnotetext{
${ }^{12}$ Para maiores detalhes, veja por exemplo Stephanes (1999).

${ }^{13}$ Disponível no site http://www.previdenciasocial.gov.br
} 
E - A restrição na concessão de isenção da contribuição patronal a entidades filantrópicas;

F - O limite mínimo de idade para a aposentadoria por tempo de serviço dos servidores públicos em 60 anos para homens e 55 para mulheres;

$\mathrm{G}$ - $\mathrm{O}$ regime misto para os novos ingressantes na administração pública.

Essas medidas estão ajudando na estabilização do déficit da previdência, no RGPS, conforme comenta Brant (2001b), pois essa nova legislação aperfeiçoou os mecanismos de arrecadação adaptando o sistema às mudanças no mercado de trabalho, e reduziu a despesa com benefícios com a eliminação da aposentadoria proporcional em idade precoce, a adequação das aposentadorias especiais e com a alteração da regra de cálculo de benefícios.

Entre as novas medidas destaca-se o novo método de cálculo do salário de benefício, que aumenta a correlação entre contribuição e benefício de forma a reduzir subsídios implícitos no sistema.

"A fórmula de cálculo atual, ao utilizar apenas os 36 últimos meses como base para a aposentadoria, provoca distorções que podem ser agravadas na medida em que as pessoas tenham uma trajetória salarial decrescente no final da sua vida laboral.

Destaca-se aqui que esta distorção assume maior gravidade quando constata-se que a maioria dos trabalhadores brasileiros apresentam este perfil, a saber os de baixa e média escolaridade

$[\ldots]$

[...] a utilização dos últimos 36 meses de contribuição como parâmetro para cálculo do salário benefício ocasiona distorções à medida em que este período representa cerca de apenas $10 \%$ do tempo de contribuição do trabalhador, ou seja, existe pouca probabilidade de que a média seja significativa.

Adiciona-se ainda o fato de ser extremamente injusto em termos sociais, pois são os trabalhadores de mais baixa renda (escolaridade baixa) os mais prejudicados" (Ornélas \& Vieira, 2002, p.10)

Com a nova metodologia de cálculo do benefício, ele será efetuado com base em toda a vida laboral do trabalhador, sendo este aumento gradativo. Além disso, protege os trabalhadores que têm vida laboral instável, inclusive com períodos de desempregos, com o 
estabelecimento da média dos salários de contribuição baseada nos $80 \%$ maiores salários de contribuição, observados durante toda a vida ativa do trabalhador.

A reforma da previdência social no serviço público, afetou diretamente a concessão de benefícios dentro do Regime Jurídico Único dos Servidores Públicos Federais. A fórmula de cálculo dos benefícios e sua indexação não foram afetados pela reforma (Brant, 2001b).

Em substituição à aposentadoria por tempo de serviço com proventos integrais, foi instituída uma combinação dos critérios de tempo de contribuição e limite de idade.

$\mathrm{Na}$ regra antiga, o lomem se aposentava com 35 anos de tempo de serviço e as mulheres com 30 anos; na nova regra, este tempo de serviço foi transformado em tempo de contribuição e foi acrescentada a exigência de uma idade mínima de 60 anos para homens e 55 para mulheres. Adicionalmente, foi instituída a necessidade de o servidor estar há 10 anos no serviço público e ter 5 anos de efetivo exercício no cargo para receber aposentadoria igual ao último salário.

Para os servidores que já estavam no quadro efetivo da Administração Pública até a data da Emenda $\mathrm{n}^{\mathbf{0}}$ 20, ficou assegurado o direito à aposentadoria voluntária pela regra de transição, ou seja, o servidor deve ter cumulativamente: 53 ou 48 anos de idade, se homem ou mulher, respectivamente; 5 anos de efetivo exercício no cargo; contar tempo de contribuição igual, no mínimo, à soma de 35 anos, se homem, 30 se mulher e período adicional de contribuição equivalente a $20 \%$ do tempo que faltava para atingir a contribuição de 35 e 30 anos, para homens e mulheres respectivamente.

Foi extinta a aposentadoria proporcional por tempo de serviço, sendo mantida apenas a aposentadoria por idade (65 anos para homens e 60 anos para mulheres), com proventos proporcionais ao tempo de contribuição. 
Observa-se que as principais modificações da reforma previdenciária têm enfoque na receita. Procurou conceituar melhor e dar maior abrangência à contribuição sobre a folha e salários, incluindo qualquer remuneração decorrente de uma atividade laboral, mas muitas distorções continuam. Stephanes (1999) alerta para os seus resultados. Segundo o exministro da previdência e assistência social, a sua eficácia será bem menor do que a esperada pelo governo. Para um bom ajuste do sistema de seguridade social, é preciso dar mais ênfase aos critérios para concessão de benefícios, que geram despesas e que possivelmente alterarão os direitos adquiridos, corrigindo, em alguns casos, a excessiva generosidade com que foram concedidas aposentadorias, refletidas em seus valores e precocidade.

Em suma, observa-se que a reforma aprovada tem muita ênfase fiscal, sob a alegação de que a manutenção do sistema até então vigente, é responsável pela elevação do déficit público, poderia acabar comprometendo a estabilidade de preços e diminuir o nível de atividade econômica, devido ao impacto sobre a taxa de juros. Com respeito ao caráter distributivo do sistema até então vigente, pouco foi revisto, e a tendência é continuar reproduzindo a distribuição de renda vigente no país, ou seja, continuourse a concentrar os benefícios nos segmentos que o mercado já privilegia. Observa-se que muitos dos princípios básicos da doutrina previdenciária continuam não sendo observados e perdeu-se a oportunidade de contribuir para a redução da desigualdade da distribuição da renda no Brasil.

Assim, os segmentos da população que formam a força de trabalho de menores rendimentos e que estão inseridos em um contexto de informalidade de vínculos empregatícios, ou ocupam postos de trabalho de baixa qualidade, com elevada rotatividade e pouca ascensão profissional, estão excluídos do sistema ou obtêm um valor de beneficio previdenciário muito baixo. 


\section{BASE DE DADOS E METODOLOGIA}

\subsection{Base de dados}

O presente estudo tem por base as informações coletadas nas Pesquisas Nacionais por Amostra de Domicílios (PNAD), no período de 1981 a 2001. A PNAD tem periodicidade anual desde 1971, sendo interrompida por ocasião dos Censos Demográficos (1970, 1980, 1991 e 2000). Trata-se de um levantamento anual realizado por meio de uma amostra dos domicílios que abrange todo o país, exceto a área rural dos estados da antiga região Norte (Acre, Amapá, Amazonas, Pará, Rondônia e Roraima). Para as pesquisas da década de 90, essa abrangência geográfica foi mantida, ou seja, a PNAD continuou a cobrir todo o país, com exceção da área rural dessas seis unidades da federação. Entretanto, visando manter a homogeneidade dos resultados produzidos a partir de 1992 para as publicações da PNAD, as estatísticas apresentadas para a região Norte referem-se somente à sua parcela urbana, não agregando as informações da área rural do Estado de Tocantins, única unidade da federação dessa região em que o levantamento não se restringiu às áreas urbanas.

Por essa pesquisa são investigados, de forma permanente, os temas habitação, rendimento e trabalho, associados a aspectos demográficos e educacionais, bem como outros assuntos de caráter demográfico, social e econômico com periodicidade variável. É uma coleta oficial de dados, realizada sob a responsabilidade do Departamento de Emprego e Rendimento da Diretoria de Pesquisa da Fundação Instituto Brasileiro de Geografia e Estatística - IBGE. 
A partir de 1992, para captar determinados grupos de pessoas envolvidas em atividade econômica que, anteriormente, não eram incluídas na população ocupada, o conceito de trabalho tornou-se mais abrangente. $\mathrm{O}$ instrumento de coleta das informações da pesquisa foi estruturado de forma que possibilita, através da realocação das parcelas correspondentes à ampliação do conceito de trabalho, gerar resultados comparáveis com os obtidos nos levantamentos das PNADs anteriores a 1992.

A comparação dos resultados da PNAD a partir de 1992 com os das décadas anteriores deve levar em conta que a classificação das áreas urbanas e rurais é feita de acordo com a legislação vigente por ocasião dos censos demográficos. Dessa forma, manteve-se a delimitação das áreas urbanas e rurais no período intercensitário, mesmo que a legislação a tenha alterado. Para as pesquisas da PNAD de 1981 a 1990, utilizou-se a classificação vigente por ocasião do Censo Demográfico de 1980; para as pesquisas da PNAD de 1992 a 1999, utilizou-se a classificação vigente por ocasião do Censo Demográfico de 1991 e para a pesquisa da PNAD de 2001, utilizou-se a classificação vigente por ocasião do Censo Demográfico de 2000. Por razões excepcionais, não foi realizada a pesquisa em 1994. Dessa forma, as estatísticas por situação urbana e rural não captam integralmente a sua evolução, sendo que as diferenças se intensificam à medida que os resultados obtidos se afastam do ano de realização do Censo Demográfico.

Ressalta-se, também, que, para as PNADs de 1992 a 1996, foram utilizados os fatores de expansão corrigidos com base na contagem populacional e divulgados juntamente com os microdados da PNAD de 1997.

Neste estudo, não são consideradas as informações das PNADs referentes a 1982 e 1987. A decisão de exclusão referente a 1982 é decorrente da diferença de procedimento na coleta dos dados neste ano (em 12 semanas de referência), em cujo intervalo houve alteração do valor do salário mínimo, enquanto nos demais anos do período considerou-se uma semana de referência. Quanto a 1987, a razão de exclusão decorre de não ter sido possível ler corretamente o arquivo de dados disponíveis. 
As informações utilizadas referem-se a dados individuais das PNADs de 1981, 1983, 1984, 1985, 1986, 1988, 1989, 1990, 1992, 1993, 1995, 1996, 1997, 1998, 1999 е 2001, fornecidas pelo IBGE, através de CD-ROM anual.

O procedimento metodológico adotado pelo IBGE implica que cada pessoa da amostra representa um determinado número de pessoas da população. Os dados individuais são fornecidos com o peso ou fator de expansão de cada indivíduo. Isso permite que os cálculos sejam elaborados ponderando-se cada observação pelo respectivo peso. Todos os cálculos, neste trabalho, foram feitos considerando o peso ou fator de expansão de cada domicílio da amostra da PNAD, fornecido pelo IBGE.

A Tabela 5 apresenta o número de domicílios particulares permanentes com declaração do rendimento domiciliar, o correspondente número de domicílios na população e o número de pessoas das categorias incluídas, excluindo pensionistas, empregados domésticos e seus parentes. Verifica-se que o tamanho da amostra era maior até 1985, foi substancialmente reduzido em 1986 e depois mostra tendência de crescimento.

Foram analisados apenas os domicílios particulares permanentes com declaração do rendimento domiciliar. Domicílios com rendimentos não declarados foram excluídos da análise.

As informações das PNADs são de boa qualidade, mas é preciso observar algumas características da natureza desses dados, as quais são restrições que precisam ser levadas em consideração na análise dos resultados, conforme alerta Hoffmann (1988 e 2002a). 
Tabela 5 . Número de domicílios e de pessoas, na amostra e na população, de 1981 a 2001

\begin{tabular}{ccccc}
\hline Ano & $\begin{array}{c}\text { Número total de } \\
\text { domicílios }\end{array}$ & $\begin{array}{c}\text { Número de domicílios } \\
\text { na população }\end{array}$ & $\begin{array}{c}\text { Número de pessoas da } \\
\text { amostra }\end{array}$ & $\begin{array}{c}\text { Número total de } \\
\text { pessoas }\end{array}$ \\
\hline 1981 & 102.315 & 25.816 .275 & 471.733 & 117.935 .916 \\
1983 & 112.681 & 27.983 .255 & 501.803 & 123.392 .346 \\
1984 & 115.748 & 28.522 .187 & 508.756 & 124.552 .197 \\
1985 & 118.159 & 30.371 .710 & 513.680 & 131.067 .725 \\
1986 & 64.674 & 29.709 .929 & 284.086 & 128.464 .816 \\
1988 & 69.237 & 29.860 .028 & 356.630 & 142.254 .224 \\
1989 & 69.617 & 32.449 .226 & 293.745 & 135.328 .418 \\
1990 & 72.028 & 33.679 .441 & 299.523 & 138.544 .788 \\
1992 & 76.183 & 34.910 .276 & 306.239 & 139.776 .617 \\
1993 & 77.624 & 35.748 .069 & 309.121 & 141.648 .005 \\
1995 & 83.233 & 38.051 .659 & 324.006 & 147.444 .210 \\
1996 & 82.358 & 38.718 .813 & 318.618 & 148.996 .894 \\
1997 & 87.754 & 39.821 .137 & 335.881 & 151.793 .468 \\
1998 & 88.365 & 40.790 .611 & 333.213 & 153.132 .933 \\
1999 & 91.574 & 41.861 .683 & 341.332 & 155.574 .996 \\
2001 & 101.156 & 45.487 .946 & 368.612 & 164.590 .222 \\
\hline
\end{tabular}

Fonte: IBGE-PNADs de 1981 a 2001.

${ }^{(1)}$ Exclusive pensionistas, empregados domésticos e parentes de empregados domésticos.

Tais restrições são:

1 - Os dados refletem rendas monetárias e pagamentos em espécie, não considerando a produção para auto-consumo. Esse aspecto leva a subestimar a renda nos estratos mais baixos, em dado momento no tempo, e pode implicar uma superestimação do nível de desigualdade dos rendimentos do setor agrícola. Além disso, este fenômeno pode afetar a comparabilidade das medidas ao longo do tempo, pois, à medida que o país se desenvolve economicamente, a tendência é diminuir a importância relativa da produção para autoconsumo;

2 - A subdeclaração dos rendimentos mais elevados, levando a uma subestimação da renda nacional e do grau de desigualdade da distribuição de renda;

3 - Alguns aspectos ligados à metodologia de coleta de dados através de questionários podem contribuir para subestimar a renda total declarada pelos indivíduos entrevistados. Nos anos 80 e início dos anos 90, o país passou por um processo inflacionário elevado, que pode ter afetado a declaração de rendimentos fixos e variáveis. Outro aspecto é a fixação da 
data de referência da coleta em determinada semana, o que pode fazer com que uma pessoa sem atividade na semana de pesquisa declare ter renda do trabalho igual a zero, mesmo que tenha trabalhado e obtido renda em outros períodos do ano.

Hoffmann (2002a) alerta que o "rendimento do trabalho", para o IBGE, é o rendimento obtido de qualquer atividade exercida e declarada pela pessoa, não se limitando aos salários. No rendimento do trabalho estão incluídos o rendimento dos conta própria e dos empregadores.

De acordo com as notas metodológicas do IBGE (2001), "conside rou-se como rendimento mensal domiciliar a soma dos rendimentos mensais dos moradores do domicílio, exclusive os das pessoas cuja condição no domicílio fosse pensionista, empregado doméstico ou parente do empregado doméstico".

Para se obter o rendimento domiciliar per capita, dividiu-se o rendimento mensal domiciliar pelo número de pessoas do domicílio, excluindo pensionistas, empregados domésticos e seus parentes.

\subsection{Metodologia}

Nesta seção, são definidas as medidas de desigualdades e apresenta-se a metodologia de decomposição do índice de Gini, que serão utilizadas no trabalho. Com o crescimento das facilidades de computação e a disponibilidade dos dados individuais, tornou-se viável o cálculo das medidas de desigualdade diretamente a partir dos dados da amostra, obtidos das PNADs de 1981 a 2001. 


\subsubsection{Medidas de desigualdade e a curva de Lorenz}

A distribuição de uma variável aleatória pode ser estudada quanto à tendência central (média aritmética, média geométrica, mediana, moda e valor central entre os extremos) e dispersão (amplitude, desvio médio, diferença média, variância e desvio padrão). Da mesma forma, existem várias medidas do grau de desigualdade de uma distribuição, tais como os índices de Gini $(G)$ e o $T$ e $L$ de Theil. Essas medidas, ou índices, são utilizadas para medir o grau de desigualdade de qualquer distribuição estatística como, por exemplo, a distribuição da posse da terra em uma região, ou a distribuição da população urbana de um país pelas cidades.

Não existe um índice de desigualdade que possa ser considerado ideal ou perfeito, nem se pode distinguir um deles, especificamente, como melhor do que os demais, pois o julgamento das vantagens e desvantagens de cada um depende da natureza da análise e envolve aspectos subjetivos.

Ramos (1993) discute sobre qual a melhor medida de desigualdade a ser adotada e conclui que não existe uma medida ideal. Dessa forma, a escolha das medidas de desigualdade leva em consideração os seguintes aspectos: a obediência ao critério de PigouDalton, o atendimento ao critério da sensibilidade decrescente a transferências e a maior difusão e emprego dos índices na literatura, o que torna possível a comparação com resultados de outros estudos. Dentre os critérios que podem ser utilizados para essa seleção, o de aceitação geral têm sido o critério de Pigou-Dalton, associado à posição da curva de Lorenz.

O critério (ou condição) de Pigou-Dalton ${ }^{14}$ estabelece que o valor das medidas de desigualdade deve aumentar quando ocorrem transferências regressivas de renda. Define-se como transferência regressiva de renda a transferência de renda de um indivíduo para um

\footnotetext{
${ }^{14}$ Essa denominação decorre do fato de essa condição ter sido apresentada por Dalton (1920), seguindo uma indicação de Pigou (1912), conforme registrado por Sem (1973)
} 
outro mais rico. Ao efetuar esse tipo de transferência, mantendo-se constante a média da distribuição, ocorre aumento no grau de desigualdade dessa distribuição.

Outro conceito amplamente utilizado é a curva de Lorenz, que é a representação gráfica da distribuição da renda. No eixo horizontal, representa-se a porcentagem acumulada de pessoas, a partir dos mais pobres, e, no eixo vertical, a porcentagem de todas as rendas recebidas em um determinado período. Considere-se, por exemplo, o conjunto das pessoas economicamente ativas residentes no Brasil. Admitindo-se que essas pessoas tenham sido ordenadas de acordo com o valor de sua renda, do mais pobre ao mais rico, define-se por curva de Lorenz a relação que mostra como a proporção acumulada da renda (Ф) varia em função da proporção acumulada da população $(p)$, conforme pode-se ver na Figura 1.

Em termos formais, pode-se apresentar a curva de Lorenz para uma variável discreta, como segue: considere uma população com $n$ valores da variável $x_{i}$, com $i=1, \ldots, n$, e admite-se que seus valores estão ordenados de maneira crescente, de forma que

$$
x_{1} \leq x_{2} \leq \ldots \leq x_{n}
$$

Considere que $x_{i}$ é a renda da $i$-ésima pessoa em uma população de $n$ pessoas. A proporção acumulada da população, até a $i$-ésima pessoa, é

$$
p_{i}=\frac{i}{n}
$$

Indicando por $\mu$ a renda média, a correspondente proporção acumulada da renda é

$$
\Phi_{i}=\frac{1}{n \mu} \sum_{j=1}^{i} x_{j}
$$


É necessário incluir as seguintes definições especiais: $p_{0}=0$ e $\Phi_{0}=0$.

Os pares de valores $p_{i}, \Phi_{i}(\operatorname{com} i=0,1, \ldots, n)$ correspondem a $(n+1)$ pontos em um sistema de eixos cartesianos ortogonais. Unindo os pontos consecutivos, obtemos uma poligonal, que é denominada "curva de Lorenz".

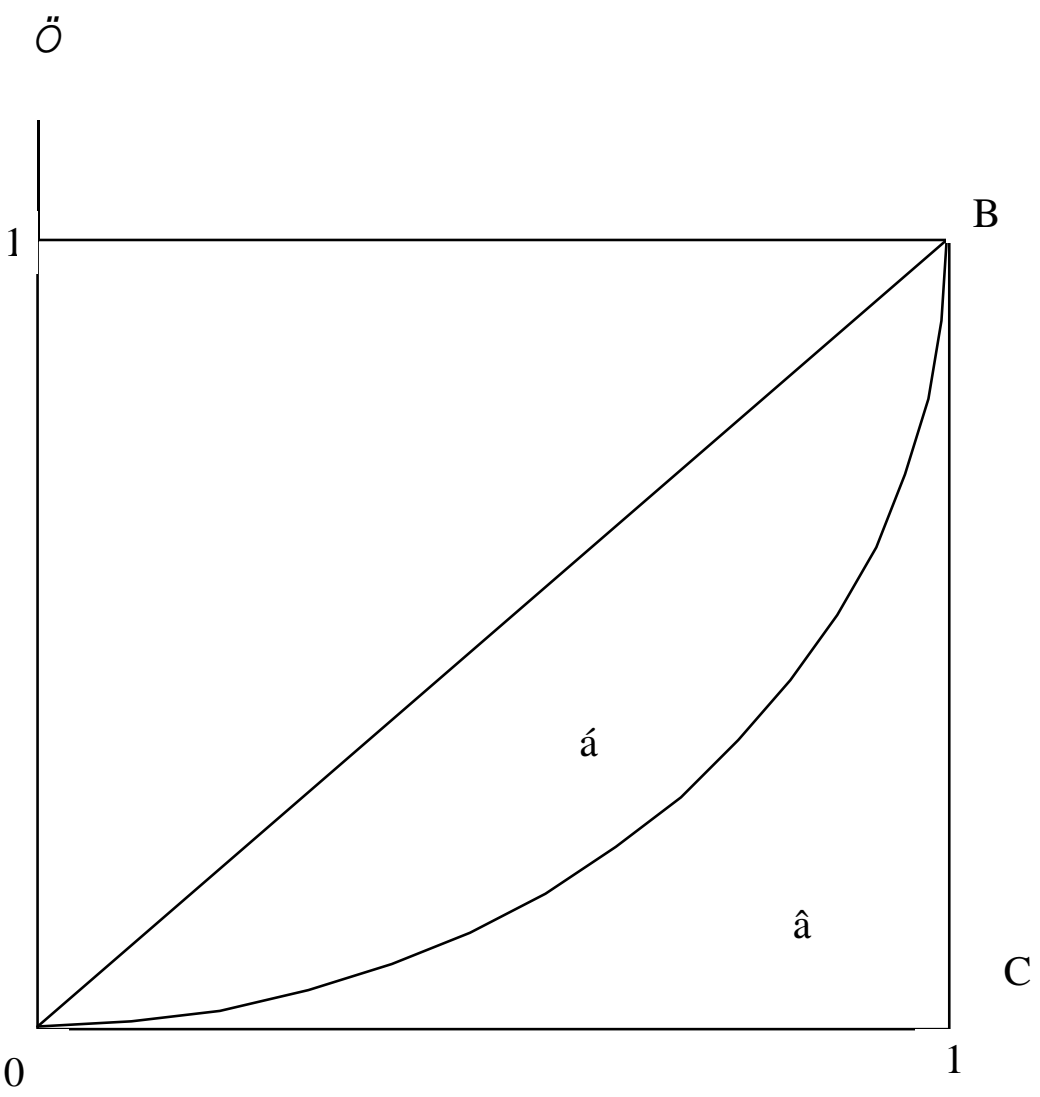

$\mathrm{C}$

$$
p
$$

Figura 1 - Curva de Lorenz

Se todas as pessoas tivessem a mesma renda, a curva de Lorenz seria o segmento de reta $\mathrm{OB}$, pertencente ao bissetor do 1 quadrante, ligando os pontos $(0,0)$ e $(1,1)$, denominado de linha de perfeita igualdade. A área $\alpha$, entre a curva de Lorenz e a linha de 
perfeita igualdade, é chamada "área de desigualdade". Como a área do triângulo OBC é igual a 0,5 , a área $a ́$ é dada por $\alpha=0,5-\beta$.

Por outro lado, se uma única pessoa se apropriasse de toda a renda e as demais $(n-1)$ pessoas não recebessem nada, a curva de Lorenz ficaria sobre o eixo das abscissas até $p=1-\frac{1}{n}$, deslocando-se em seguida para o ponto B. Quanto maior a desigualdade na distribuição de renda, mais convexa a curva se torna, afastando-se da linha de perfeita igualdade.

A seguir são apresentadas as medidas de desigualdade que serão utilizadas neste trabalho.

\subsubsection{O índice de Gini $(G)$}

O coeficiente proposto por Gini ${ }^{15}$ é a medida de desigualdade de uso mais comum em análises empíricas. A área compreendida entre a linha de perfeita igualdade e a curva de Lorenz é a área de desigualdade, indicada por $\alpha$, conforme a figura 1 . Sabendo que a área do triângulo $\mathrm{OBC}$ é igual a 0,5 , verifica-se que

$$
0 \leq \alpha<0,5
$$

Na situação de máxima desigualdade, quando uma pessoa fica com toda a renda, a área de desigualdade é um triângulo cuja base (no eixo das abscissas) é igual a $1-\frac{1}{n}$ e cuja altura é igual a 1. Então, o valor máximo de $\alpha$ para a distribuição discreta com $x \geq 0$ é

\footnotetext{
${ }^{15} \mathrm{O}$ índice de Gini é uma das principais medidas de desigualdade. Segundo Sen(1973), esse coeficiente é atribuído a Gini (1912), e também foi analisado por Ricci (1916), Dalton (1920), Yntema (1938), Atkinson (1970) e outros.
} 


$$
\alpha_{\max }=\frac{1}{2}\left(1-\frac{1}{n}\right)
$$

e temos

$$
0 \leq \alpha \leq \frac{1}{2}\left(1-\frac{1}{n}\right)
$$

Note que $\lim _{n \rightarrow \infty} \alpha_{\max }=0,5$

O índice de Gini $(G)$ é definido como o quociente entre a área de desigualdade $(\alpha)$ e a área do triângulo $\mathrm{OBC}$, ou seja,

$$
G=\frac{\alpha}{0,5}=2 \alpha
$$

Verifica-se que o índice de Gini é um número adimensional, tal que $0 \leq G \leq 1-\frac{1}{n}$.

Uma das principais vantagens do índice de Gini, de acordo com Hoffmann (1998), é a sua associação direta com a posição da curva de Lorenz.

A área compreendida entre a curva de Lorenz e o eixo das abscissas será indicada por $\beta$ e já foi mostrado que

$$
\alpha=0,5-\beta
$$

A área de $\beta$ é formada por trapézios como o repr esentado na Figura 2. 


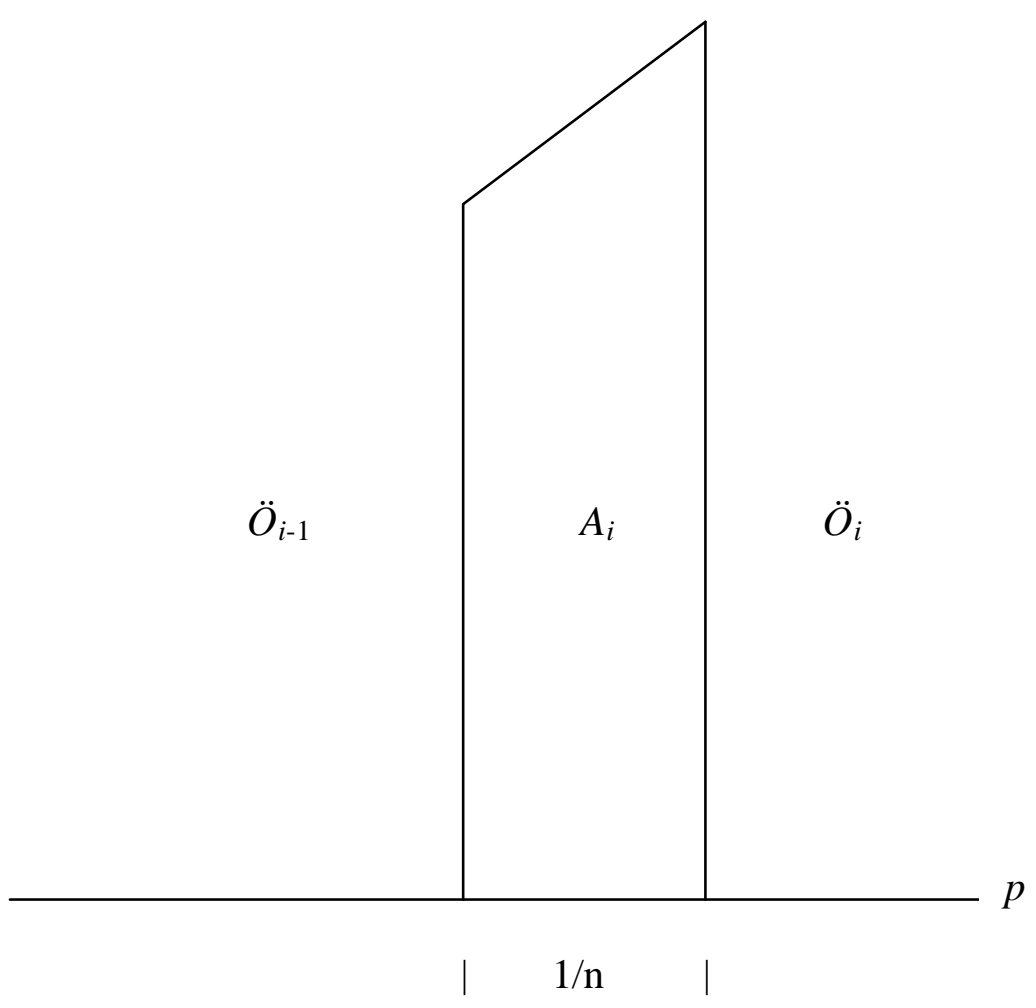

Figura 2 - Um dos trapézios que formam a área $\beta$

Seja $A_{i}$ a área do $i$-ésimo trapézio, com base maior $\Phi_{i}$, base menor $\Phi_{i-1}$ e altura $p_{i}-p_{i-1}=\frac{1}{n}$. Então,

$$
A_{i}=\frac{1}{2 n}\left(\Phi_{i}+\Phi_{i-1}\right)
$$

Fazendo $\Phi_{0}=0$, temos:

$$
\beta=\sum_{i=1}^{n} A_{i}
$$


$\beta=\frac{1}{2 n} \sum_{i=1}^{n}\left(\Phi_{i}+\Phi_{i-1}\right)$

Das equações (5) e (6), obtém-se

$G=1-2 \beta$

De acordo com a equação (9), tem-se que

$$
G=1-\frac{1}{n} \sum_{i=1}^{n}\left(\Phi_{i}+\Phi_{i-1}\right)
$$

Há várias outras fórmulas para o cálculo do índice de Gini, como mostra, por exemplo, Hoffmann (1998). Para calcular o índice a partir das rendas individuais $x_{i}$, pode-se utilizar a expressão

$$
G=\frac{2}{n^{2} \mu} \sum_{i=1}^{n} i x_{i}-\left(1+\frac{1}{n}\right)
$$

onde $\mu$ é a média da distribuição de $x$.

\subsubsection{Os índices $\mathrm{T}$ e $\mathrm{L}$ de Theil}

Com base na teoria da informação, Theil (1967) propôs duas medidas de desigualdade. Considere uma população de $n$ pessoas cujas rendas são indicadas por $x_{i}(i=$ $1, \ldots, n)$. O índice $\mathrm{T}$ de Theil $(T)$ pode ser calculado por: 


$$
T=\sum_{i=1}^{n} y_{i} \cdot \ln n y_{i}
$$

em que:

$y_{i}=\frac{x_{i}}{n \mu}$ é a participação da $i$-ésima pessoa na renda total.

Pode-se verificar que $T=0$ no caso de distribuição com perfeita igualdade e $T=\ln n$ no caso de máxima desigualdade. Portanto, $0 \leq T \leq \ln n$. Pode-se usar a transformação monotonicamente crescente

$$
U=1-\exp (-T)
$$

que varia de zero a $\frac{(n-1)}{n}$, que é o mesmo intervalo de variação do índice de Gini. O índice $U$ é denominado dual do T de Theil.

O dual $U$ é a proporção que ficaria sem renda em uma situação hipotética em que a renda total fosse igualitariamente distribuída entre $(1-U)_{n}$ pessoas, deixando as demais Un pessoas sem renda, de maneira que o valor do $T$ de Theil nessa distribuição hipotética fosse igual ao da distribuição analisada. Ressalta-se que, em comparação com o índice de Gini, o $T$ de Theil é relativamente mais sensível a mudanças nas rendas dos ricos.

A segunda medida de desigualdade de Theil é denominada $L$ de Theil, dada por

$$
L=\frac{1}{n} \sum_{i=1}^{n} \ln \frac{1}{n y_{i}}=\frac{1}{n} \sum_{i=1}^{n} \ln \frac{\mu}{x_{i}}
$$

em que $x_{i}$ é a renda da $i$-ésima pessoa e $\mu$ é a renda média. 
Expressa de outra forma, essa medida é definida como o logaritmo da razão entre as médias aritmética e geométrica das rendas, isto é,

$$
L=\ln \frac{\mu}{\mu_{g}}
$$

em que $\mu_{\mathrm{g}}$ é a média geométrica das rendas $x_{\mathrm{i}}$.

Em decorrência, uma fórmula prática para o cálculo de $L$ é

$$
L=\ln \left[\frac{1}{n} \sum_{i=1}^{n} x_{i}\right]-\frac{1}{n} \sum_{i=1}^{n} \ln x_{i}
$$

Essa medida de desigualdade não pode ser calculada quando há rendas nulas, pois neste caso a média geométrica também é zero, e o índice não é definido. Se uma das rendas tende a zero, $L$ tende a infinito. Se todas as rendas são iguais, como no caso de perfeita igualdade, o valor de $L$ é zero. $\mathrm{O} L$ de Theil é uma medida de desigualdade especialmente sensível ao que ocorre entre os relativamente pobres, na cauda esquerda da distribuição da renda.

\subsubsection{Outras medidas de desigualdade}

Além dos índices de Gini $(G)$ e do $T$ de Theil, este trabalho utiliza outras medidas de desigualdade, tal como a porcentagem da renda em poder dos $50 \%$ mais pobres (50), dos $10 \%$ mais ricos $\left(10^{+}\right)$, dos $5 \%$ mais ricos $\left(5^{+}\right)$, ou dos $1 \%$ mais ricos $\left(1^{+}\right)$. Esses índices são medidas associadas diretamente à posição de um único ponto da curva de Lorenz, ou seja, às separatrizes (decis e percentis) da distribuição do rendimento. Ressalta-se que essas medidas não atendem ao princípio de Pigou-Dalton. Por exemplo, a proporção da renda apropriada pelos $5 \%$ mais ricos $\left(5^{+}\right)$não obedece à condição de Pigou-Dalton, pois "não é afetada por transferências entre pessoas que estejam e permaneçam abaixo do $95^{\circ}$ percentil ou entre 
pessoas que estejam e permaneçam acima deste percentil" (Corrêa, 1995, p.62). A vantagem desses índices é sua interpretação simples, fazendo com que sejam largamente utilizados na literatura especializada.

\subsubsection{Decomposição do índice de Gini}

Neste trabalho, utiliza-se a decomposição do Índice de Gini para analisar a contribuição das aposentadorias e pensões para a desigualdade da distribuição do rendimento domiciliar per capita no Brasil ao longo das décadas de 80 e 90. Essa decomposição da desigualdade considera os vários componentes que se somam para formar os rendimentos domiciliares.

A metodologia de decomposição do coeficiente de Gini utilizada neste trabalho está baseada no artigo de Pyatt et al. (1980). Essa metodologia já foi utilizada por muitos autores, podendo-se citar Fei et al. (1978), Ercelawn (1984), Mariano \& Lima (1998), Neder (2001), Hoffmann (2002a e 2002c).

O ponto inicil é assumir que há $n$ pessoas e que $z_{i}$ e $t_{i}$ são duas variáveis quaisquer observadas nas pessoas com $(i=1,2, \ldots, n)$. As pessoas terão uma posição de ordem de acordo com $t_{i}$ : a posição da pessoa na colocação $i$ será denominada $r\left(t_{i}\right)$, com a convenção de que $r\left(t_{i}\right)=1$ para a pessoa com o $t_{i}$ menor e $r\left(t_{i}\right)=n$ para a pessoa com o maior $t_{i}$. Se duas ou mais pessoas tiverem o mesmo valor para $t_{i}$, para cada uma delas será dada a média das posições que essas pessoas poderão ter se houver uma diferença infinitesimal entre elas. Dessa forma, a média de todas as posições $r\left(t_{i}\right)$ é dada por:

$$
\bar{r}=\frac{1}{n} \sum_{i=1}^{n} r\left(t_{i}\right)=\frac{(n+1)}{2}
$$


A média das posições é, portanto, independente do critério de "posicionamento" $t_{i}$ que é dado.

Admite-se que o valor médio de $z_{i}$ é positivo, isto é,

$$
\bar{z}=\frac{1}{n} \sum_{i=1}^{n} z_{i}>0
$$

Note-se que $z_{i}$ não necessita ser positivo para todo $i$.

Dado $\bar{z}$, pode-se também definir:

$$
\pi_{i}=\frac{z_{i}}{n \bar{z}}
$$

para cada pessoa. De (18) e (19) tem-se que a soma dos $n$ valores de $\pi_{i}$ é igual a 1.

A curva de concentração de $z_{i}$ em relação a $t_{i}$ mostra como os valores acumulados dos $\pi_{i}$ variam em função de $\frac{r\left(t_{i}\right)}{n}$, tendo-se previamente ordenado as pessoas conforme valores crescentes de $r\left(t_{i}\right)$. A Figura 3 ilustra a construção da curva de concentração. Notese que essa curva não precisa ser monotonicamente crescente. A curva pode ficar acima do bissetor do primeiro quadrante. Se houver valores negativos de $z_{i}$, a curva pode ficar abaixo do eixo das abcissas. 


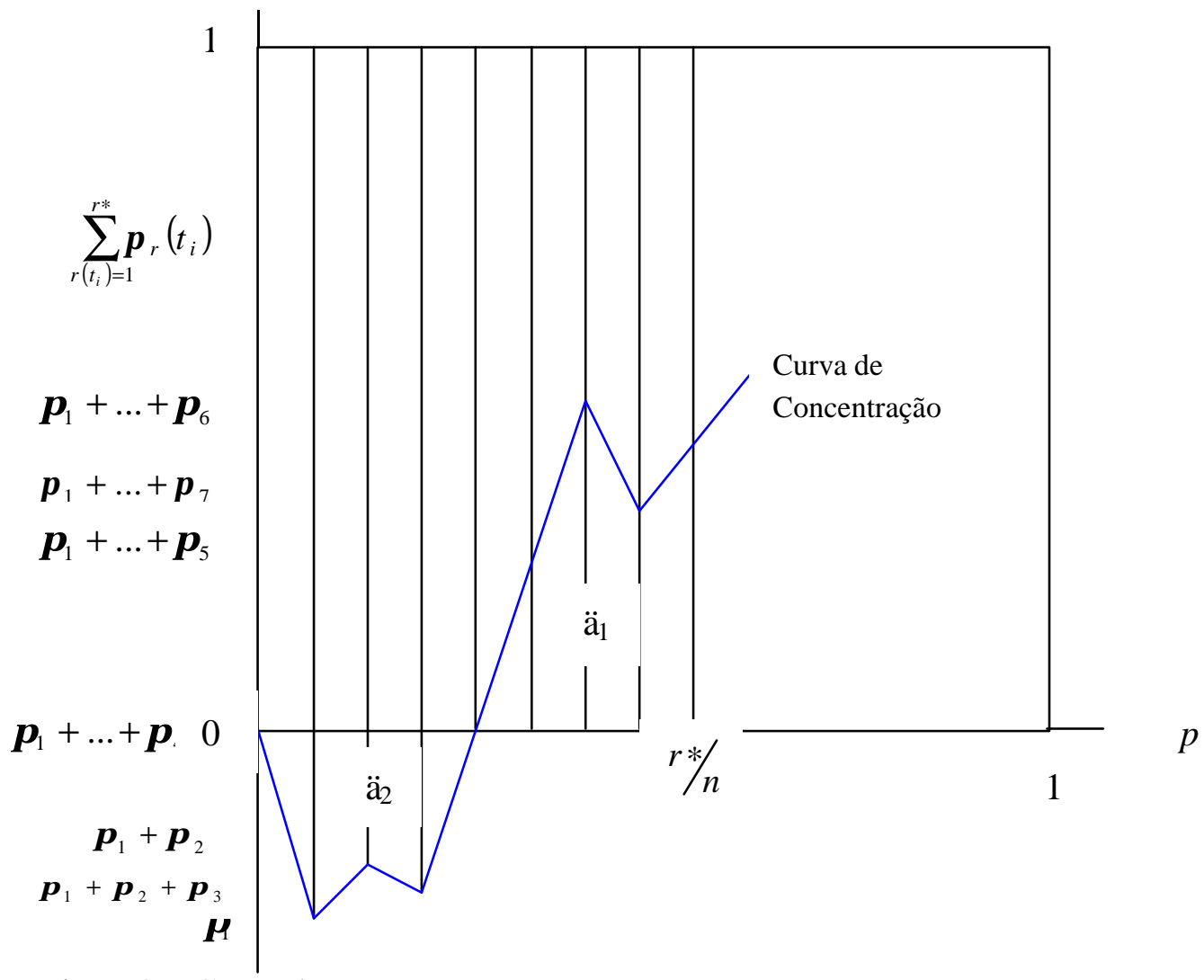

Figura 3 - Curva de concentração

A razão de concentração de $z$ em relação a $t$, indicada por $C(z \mid t)$, é definida como 1 menos duas vezes a área entre a curva de concentração e o eixo das abcissas, ou seja,

$$
C(z \mid t)=1-2 \delta
$$

Note-se a semelhança entre as expressões (10) e (20). Cabe ressaltar que áreas delimitadas pela curva de concentração abaixo do eixo das abcissas são negativas. Assim, no caso da Figura 3, tem-se $\delta=\boldsymbol{\delta}_{1}-\boldsymbol{\delta}_{2}$. 
Observando a Figura 3, verifica-se que a área abaixo da curva de concentração pode ser obtida através da soma das áreas de $n$ trapézios verticais, cada um com altura de $\left(\frac{1}{n}\right)$, isto é, como:

$$
\begin{aligned}
& \boldsymbol{\delta}=\frac{1}{2} \cdot \frac{1}{n}\left[\pi_{1}+\sum_{i=2}^{n}\left(\sum_{j=1}^{i-1} \pi_{j}+\sum_{j=1}^{i} \pi_{j}\right)\right] \\
& \delta=\frac{1}{2} \cdot \frac{1}{n} \sum_{i=1}^{n} \pi_{i}[1+2(n-i)]
\end{aligned}
$$

em que o subscrito $i$ refere-se à posição de ordem da pessoa, ou seja, $i=r\left(t_{i}\right)$.

De (21) tem-se que a razão de concentração é:

$$
C(z \mid t)=1-\frac{1}{n} \sum_{i=1}^{n} \pi_{i}[1+2(n-i)]
$$

Lembrando a expressão (17), após algumas transformações algébricas verifica-se que

$$
C(z \mid t)=\frac{2}{n} \sum_{i=1}^{n} \pi_{i}\left[r\left(t_{i}\right)-\bar{r}\right]
$$

ou

$$
C(z \mid t)=2 \operatorname{cov}[\pi(z), r(t)]
$$

em que cov $(a, b)$ é a covariância entre as variáveis $a$ e $b$. Utilizando (19), segue-se que 


$$
C(z \mid t)=2 \operatorname{cov}\left[\left(\frac{z}{n \bar{z}}\right), r(t)\right]
$$

ou

$$
C(z \mid t)=\frac{2}{n \bar{z}} \operatorname{cov}[z, r(t)]
$$

Se a variável $z$ for não-negativa $\left(z_{i} \geq 0\right.$ para todo $\left.i\right)$, verifica-se que a área abaixo da curva de concentração varia de $(2 n)^{-1}$ a $1-(2 n)^{-1}$, de maneira que

$$
\frac{1}{n}-1 \leq C(z \mid t) \leq 1-\frac{1}{n}
$$

No caso particular em que a própria variável $z$ for utilizada para ordenar os valores, isto é, se $t=z$, a curva de concentração passa a ser a curva de Lorenz da distribuição de $z$ e a razão de concentração é o respectivo índice de Gini.

Se $y_{i}$ é a renda domiciliar per capita e as pessoas estiverem ordenadas conforme o valor dessa mesma variável, o índice de Gini da renda domiciliar per capita é

$$
G(y)=C(y \mid y)=\frac{2}{n \bar{y}} \operatorname{cov}[y, r(y)]
$$

Se $x_{i k}$ é a contribuição da parcela $k$ (por exemplo, a aposentadoria) para a renda domiciliar per capita $y_{i}$, então:

$$
y_{i}=\sum_{k=1}^{m} x_{i k} \quad \text { para } \quad i=1, \ldots, n
$$


em que a renda total é constituída por $m$ parcelas $(k=1, \ldots, m)$. Segue-se que

$$
\bar{y}=\sum_{k=1}^{m} \bar{x}_{k}
$$

em que $\bar{x}_{k}$ é a média de $x_{i k}$ para as $n$ pessoas.

Substituindo (26) em (25), tem-se:

$$
\begin{aligned}
& G(y)=\frac{2}{n \bar{y}} \operatorname{cov}\left[\sum_{k} x_{i k}, r(y)\right] \\
& G(y)=\frac{2}{n \bar{y}} \sum_{k} \operatorname{cov}\left[x_{i k}, r(y)\right]
\end{aligned}
$$

Lembrando (24), verifica-se que

$$
G(y)=\sum_{k=1}^{m} \phi_{k} C\left(x_{k} \mid y\right)
$$

em que:

$$
\phi_{k}=\frac{\bar{x}_{k}}{\bar{y}}
$$

Note-se que $\phi_{k}$ é a participação da $k$-ésima parcela na renda total.

É interessante verificar como a razão de concentração de $x_{k}$ em relação a $y$ se relaciona com o índice de Gini de $x_{k}$, que é dado por 


$$
G\left(x_{k}\right)=\frac{2}{n \bar{x}_{k}} \operatorname{cov}\left[x_{k}, r\left(x_{k}\right)\right] .
$$

Usando (24), tem-se:

$$
\frac{C\left(x_{k} \mid y\right)}{G\left(x_{k}\right)}=\frac{\operatorname{cov}\left[x_{k}, r(y)\right]}{\operatorname{cov}\left[x_{k}, r\left(x_{k}\right)\right]}=R\left(y, x_{k}\right)
$$

$R\left(y, x_{k}\right)$ é denominada razão de correlação de ordem, cabendo ressaltar que não é um coeficiente de correlação de ordem. A expressão (31) mostra que a razão será igual a um somente se:

$$
r(y)=r\left(x_{k}\right)
$$

ou seja, somente se as pessoas tiverem o mesmo ordenamento com respeito à parcela de renda $k$ e com respeito à renda domiciliar per capita.

Para obter $G\left(x_{k}\right)$, as pessoas são ordenadas conforme valores crescentes de $x_{i k}$. Em geral, o ordenamento será diferente no cálculo de $C\left(x_{k} \mid y\right)$, quando as pessoas são ordenadas pelo valor de $y_{i}$. É claro que o valor acumulado dos $x_{i k}$ até uma posição $h$ será mínimo quando a ordenação tiver sido feita conforme os próprios valores de $x_{i k}$. Em outras palavras, a curva de concentração de $x_{k}$ em relação a $y$ nunca poderá ficar abaixo da curva de Lorenz de $x_{k}$. Conseqüentemente, a razão de concentração de $x_{k}$ em relação a $y$ não pode exceder o índice de Gini de $x_{k}$, isto é,

$$
\frac{C\left(x_{k} \mid y\right)}{G\left(x_{k}\right)}=R\left(y, x_{k}\right)=R_{k} \leq 1 .
$$

Esse resultado também poderia ser obtido considerando que 
$\operatorname{cov}[z, r(z)] \geq \operatorname{cov}[z, r(t)]$ para todo $t$.

Hoffmann (2002a) observa que, na expressão (28), se todas as razões de concentração tivessem o mesmo valor, esse seria também o valor de $G(y)$. Dessa forma, ele considera que um componente $x_{i k}$ contribui para aumentar a desigualdade quando $C\left(x_{k} \mid y\right)>G(y)$. Quando $C\left(x_{k} \mid y\right)<G(y)$, o componente $x_{i k}$ já está contribuindo para reduzir a desigualdade em relação àquela situação hipotética de igualdade das razões de concentração.

Esta metodologia de decomposição do índice de Gini foi utilizada no Brasil por Mariano \& Lima (1998) para identificar as fontes da renda rural que contribuem para aumentar ou diminuir a desigualdade da renda no campo.

O trabalho de Neder (2001) utilizou essa metodologia de decomposição visando verificar quais foram, especificamente, as fontes de renda que mais têm contribuído para a concentração de renda da população rural, destacando os rendimentos não-agrícolas.

Hoffmann (2002a) analisou a contribuição dos componentes do rendimento domiciliar para a desigualdade da distribuição do rendimento domiciliar per capita. Utilizando dados da PNAD de 1999, ele fez a decomposição do índice de Gini da distribuição do rendimento domiciliar per capita, considerando o rendimento do trabalho principal das pessoas ocupadas, rendimentos de outros trabalhos, aposentadorias e pensões, doações, aluguéis e uma parcela constituída por juros, dividendos e outros rendimentos, para o Brasil, Brasil metropolitano, Brasil urbano não-metropolitano e Brasil rural não-metropolitano. Os resultados mostram que os rendimentos do trabalho principal dão origem à maior parcela do índice de Gini, seguido pelos rendimentos das aposentadorias e pensões. 
Fei et al. (1978) desenvolveram a metodologia para a decomposição estatística da desigualdade da renda familiar, cujos componentes eram salário, renda obtida por atividades agrícolas, renda proveniente de propriedades, entre outras. A medida de desigualdade utilizada por eles foi o coeficiente de Gini porque apresenta propriedades e características estatísticas adequadas que facilitam o seu entendimento.

\subsubsection{Fórmula de cálculo com ponderação e exemplo numérico de de composição}

Nesta seção serão desenvolvidas fórmulas de cálculo das razões de concentração quando os dados individuais devem ser ponderados, como acontece na PNAD. Também será apresentado um exemplo numérico para ilustrar os cálculos da decomposição do índice de Gini.

Seja $w_{i}$ o peso ou fator de expansão associado à renda $y_{i}$ e a suas parcelas $x_{i k}$ (com $k=1, \ldots, m$ e $i=1, \ldots, n$ ). Admite-se que as rendas $y_{i}$ estão ordenadas de maneira que $y_{1} \leq y_{2} \leq \ldots \leq y_{n}$.

Seja $N$ o total dos fatores de expansão:

$$
N=\sum w_{i}
$$

A renda total é $S=\sum w_{i} y_{i}$ e o total da $k$-ésima parcela é $S_{k}=\sum w_{i} x_{i k}$. As respectivas médias são

$$
\bar{y}=\frac{1}{N} \sum w_{i} y_{i}=\frac{S}{N}
$$




$$
\bar{x}_{k}=\frac{1}{N} \sum w_{i} x_{i k}=\frac{S_{k}}{N} \quad(k=1, \ldots, m)
$$

A fração da renda total correspondente à $k$-ésima parcela é

$$
\phi_{k}=\frac{\sum w_{i} x_{i k}}{\sum w_{i} y_{i}}=\frac{\bar{x}_{k}}{\bar{y}}
$$

Já foi visto que, para dados discretos (população finita), a curva de concentração de uma parcela é uma poligonal. A abcissa do $i$-ésimo vértice dessa poligonal é

$$
p_{i}=\frac{1}{N} \sum_{j=1}^{i} w_{j}
$$

A respectiva ordenada é

$$
\Phi_{i k}=\frac{1}{S_{k}} \sum_{j=1}^{i} w_{j} x_{j k}
$$

A área do $i$-ésimo trapézio abaixo da curva de concentração de $x_{i k}$ é

$$
A_{i k}=\frac{1}{2}\left(\Phi_{i k}+\Phi_{i-1, k}\right)\left(p_{i}-p_{i-1}\right)
$$

Lembrando (36) e (37), segue-se que

$$
A_{i k}=\frac{1}{2 N S_{k}}\left(\sum_{j=1}^{i-1} w_{j} x_{j k}+\sum_{j=1}^{i} w_{j} x_{j k}\right) w_{i}
$$

ou 


$$
A_{i k}=\frac{w_{i}}{N S_{k}}\left(\sum_{j=1}^{i-1} w_{j} x_{j k}+\frac{w_{i} x_{i k}}{2}\right)
$$

Fazendo

$$
q_{i k}=\sum_{j=1}^{i-1} w_{j} x_{j k}+\frac{1}{2} w_{i} x_{i k}
$$

obtém-se

$$
A_{i k}=\frac{w_{i} q_{i k}}{N S_{k}}
$$

Então a área abaixo da curva de concentração é

$$
\frac{1}{N S_{k}} \sum_{i=1}^{n} w_{i} q_{i k}
$$

e a razão de concentração de $x_{i k}\left(\right.$ em relação a $\left.y_{i}\right)$ é

$$
C\left(x_{k} \mid y\right)=1-\frac{2}{N S_{k}} \sum_{i=1}^{n} w_{i} q_{i k}
$$

Lembrando que o índice de Gini da distribuição de $y_{i}$ é a razão de concentração de $y$ em relação a ele mesmo, e definindo, analogamente a (40),

$$
q_{i}=\sum_{j=1}^{i-1} w_{j} y_{j}+\frac{1}{2} w_{i} y_{i}
$$


tem-se

$$
G=1-\frac{2}{N S} \sum_{i=1}^{n} w_{i} q_{i}
$$

Para ilustrar os cálculos, será utilizado um exemplo muito simples de uma população com apenas 5 pessoas, com rendas 1, 1, 2, 6 e 30. Isso é equivalente a considerar apenas 4 rendas $\left(y_{i}\right)$ distintas $\left(1,2,6\right.$ e 30) e fatores de expansão $\left(w_{i}\right)$ iguais a 2, 1,1 e 1 . Admite-se que a renda $y_{i}$ é formada por 3 parcelas $\left(x_{1}, x_{2}\right.$ e $\left.x_{3}\right)$, cujos valores estão na Tabela 6. Essa tabela mostra os dados e alguns cálculos básicos para a decomposição do índice de Gini da distribuição de $y$.

Tabela 6. Exemplo numérico artificial com 4 rendas e cálculos básicos para decomposição do índice de Gini

\begin{tabular}{ccccccccccc}
\hline $\begin{array}{c}\text { Ordem } \\
(i)\end{array}$ & $w_{i}$ & $y_{i}$ & $w_{i} y_{i}$ & $x_{i 1}$ & $x_{i 2}$ & $x_{i 3}$ & $q_{i}$ & $q_{i 1}$ & $q_{i 2}$ & $q_{i 3}$ \\
\hline 1 & 2 & 1 & 2 & 1 & 0 & 0 & 1 & 1 & 0 & 0 \\
2 & 1 & 2 & 2 & 0 & 2 & 0 & 3 & 2 & 1 & 0 \\
3 & 1 & 6 & 6 & 0 & 2 & 4 & 7 & 2 & 3 & 2 \\
4 & 1 & 30 & 30 & 0 & 2 & 28 & 25 & 2 & 5 & 18 \\
Total & 5 & & 40 & & & & & & & \\
\hline
\end{tabular}

Verifica-se que $N=5, S=40, S_{1}=2, S_{2}=6$ e $S_{3}=32$. A renda média é 8 e as médias das parcelas são $\bar{x}_{1}=0,4, \bar{x}_{2}=1,2$ e $\bar{x}_{3}=6,4$.

A equação (35) permite calcular as participações de cada parcela no rendimento total, que são: $\phi_{1}=0,05 ; \phi_{2}=0,15$ e $\phi_{3}=0,8$. 
Utilizando a equação (41), podem ser calculadas as razões de concentração para as três parcelas, que são $C_{1}=-0,6 ; C_{2}=0,4$ e $C_{3}=0,75$.

A equação (43) mostra o cálculo do índice de Gini global. No exemplo, esse índice é: $G=0,63$. Pode-se verificar que, de acordo com (28),

$$
\begin{aligned}
& G=\sum_{k=1}^{3} \phi_{k} C\left(x_{k} \mid y\right) \\
& G=0,05 \cdot(-0,6)+0,15 \cdot 0,4+0,8 \cdot 0,75 \\
& G=-0,03+0,06+0,60
\end{aligned}
$$

Observa-se que $C\left(x_{3} \mid y\right)>G(y)$ e portanto o componente $x_{3}$ contribui para aumentar a desigualdade.

Esse exemplo numérico simples pode ser útil para verificar programas para computador destinados a fazer a decomposição do índice de Gini conforme parcelas do rendimento. 


\title{
4 EVOLUÇÃO DA DESIGUALDADE: ANÁLISE BASEADA EM ESTRATOS DO RENDIMENTO DOMICILIAR PER CAPITA E DECOMPOSIÇÃO DO ÍNDICE DE GINI
}

\author{
Neste capítulo apresentam-se os resultados obtidos para: as medidas de \\ desigualdade de renda; a análise baseada em estratos de rendimento domiciliar per \\ capita e a decomposição do índice de Gini para o Brasil, de 1981 a 2001.
}

\subsection{Desigualdade do rendimento domiciliar per capita no Brasil: 1981 a 2001}

O objetivo específico desta seção é apresentar uma análise descritiva da evolução da desigualdade do rendimento domiciliar per capita no país, no período de 1981 a 2001. Os resultados aqui apresentados buscam refletir a situação do conjunto das pessoas que formam os domicílios brasileiros quanto ao aspecto da distribuição dos seus rendimentos.

Vale lembrar que, para se calcular o L de Theil, é necessário excluir os domicílios com rendimento declarado igual a zero, porque esse índice tende a infinito quando a renda de um domicílio tende a zero. Dessa forma, apresenta-se na Tabela 7 uma coluna contendo a porcentagem de domicílios que foram desconsiderados para esse cálculo por terem rendimento igual a zero. Cabe ressaltar que todos os demais indicadores de desigualdade foram calculados incluindo os domicílios com rendimento igual a zero.

A Tabela 7 e a Figura 4 mostram a evolução da desigualdade do rendimento domiciliar per capita obtidos através do cálculo do índice de Gini, T de Theil e L de Theil. 
Observa-se que a desigualdade manteve-se elevada durante todo o período analisado. Notase o sistemático crescimento da desigualdade após o Plano Cruzado em 1986, o valor excepcionalmente baixo em 1992 e novamente um crescimento, mantendo-se relativamente estável no período 1993-1997. Ocorre uma pequena diminuição da desigualdade entre 1998 e 1999. Observa-se na Tabela 7 que, excetuando 1981, 1984, 1986 e 1992, as medidas de desigualdade em 1999 são menores do que em qualquer outro ano do período analisado. Em 2001, observa-se que a desigualdade voltou a ter um pequeno crescimento.

Vale lembrar que, de 1970 a 1980, o PIB per capita do Brasil cresceu $81 \%$ ou $6,1 \%$ ao ano. No início dos anos 80 , esse crescimento foi interrompido, diminuindo para $12,4 \%$ entre 1980 e 1983. Em 1989, o PIB per capita era apenas $2 \%$ maior do que o de 1980, e em 1990 cai substancialmente, tornando-se 4,3\% menor do que o de 1980 (Hoffmann, 1995).

Observa-se uma pequena redução da desigualdade em 1986 devido ao efeito benéfico do Plano Cruzado. De 1988 a 1989, todos os indicadores mostram um intenso crescimento da desigualdade, que parece estar associado à aceleração da inflação.

De acordo com Hoffmann (1995), a inflação acelerada provoca um efeito real de aumento da desigualdade devido ao atraso sistemático no reajuste dos rendimentos de certos grupos de pessoas. Os salários, de maneira geral, tendem a perder valor real em comparação com juros e lucros, aumentando a desigualdade da distribuição da renda. Outro efeito do aumento da inflação é o "ruído" estatístico. Com inflação alta, o valor nominal das remunerações sofre grandes mudanças de um mês para outro. Por exemplo, dois trabalhadores com o mesmo salário real médio em 1989 podiam estar com salários nominais muito diferentes em setembro daquele ano, se um deles pertencesse a uma categoria que obteve reajuste salarial em setembro e outro pertencesse a uma categoria que obteve reajuste em outubro. A inflação alta também faz as pessoas perderem a noção dos valores monetários, aumentando os erros de declaração.

As pessoas que se encontram entre os $10 \%$ mais ricos se apropriam de aproximadamente $48 \%$ do total da renda, enquanto os $50 \%$ mais pobres detêm cerca de $12 \%$ 
da renda, conforme pode-se ver na Figura 5 e Tabela 7. A razão entre a renda total dos $10 \%$ mais ricos e a renda total dos $50 \%$ mais pobres em 2001 foi de 3,7 , ou seja, as pessoas que compõem os $10 \%$ mais ricos detém uma renda 3,7 vezes maior do que toda a renda dos $50 \%$ mais pobres.

Tabela 7. Distribuição do rendimento domiciliar per capita, no Brasil, de 1981 a 2001: Índice de Gini $(G)$, T de Theil $(T)$, L de Theil $(L)$, percentual de domicílios com rendimento igual a zero, percentagem da renda correspondente aos $50 \%$ mais pobres (50-) e aos $10 \%$ mais ricos (10+)

\begin{tabular}{ccccccc}
\hline Anos & $\mathrm{G}^{(1)}$ & $\mathrm{T}^{(1)}$ & $\mathrm{L}^{(2)}$ & $\begin{array}{c}\text { \% rendimento } \\
\text { igual a zero }\end{array}$ & $50-^{(1)}$ & $10+{ }^{(1)}$ \\
\hline 1981 & 0,582 & 0,675 & 0,625 & 0,65 & 13,2 & 46,2 \\
1983 & 0,594 & 0,712 & 0,644 & 0,93 & 12,6 & 47,1 \\
1984 & 0,587 & 0,695 & 0,630 & 0,47 & 13,7 & 47,0 \\
1985 & 0,595 & 0,718 & 0,659 & 0,41 & 12,6 & 47,5 \\
1986 & 0,586 & 0,713 & 0,635 & 0,36 & 13,1 & 46,8 \\
1988 & 0,616 & 0,785 & 0,722 & 0,49 & 11,6 & 49,6 \\
1989 & 0,634 & 0,880 & 0,774 & 0,49 & 10,7 & 51,2 \\
1990 & 0,612 & 0,766 & 0,711 & 0,82 & 11,5 & 48,6 \\
1992 & 0,580 & 0,689 & 0,634 & 1,19 & 13,2 & 45,6 \\
1993 & 0,602 & 0,765 & 0,685 & 1,01 & 12,4 & 48,4 \\
1995 & 0,599 & 0,727 & 0,665 & 1,26 & 12,4 & 47,7 \\
1996 & 0,600 & 0,726 & 0,670 & 1,67 & 12,2 & 47,3 \\
1997 & 0,600 & 0,731 & 0,673 & 1,38 & 12,2 & 47,5 \\
1998 & 0,598 & 0,728 & 0,662 & 1,31 & 12,4 & 47,6 \\
1999 & 0,592 & 0,706 & 0,645 & 1,25 & 12,8 & 47,1 \\
2001 & 0,594 & 0,720 & 0,650 & 1,56 & 12,7 & 47,2 \\
\hline
\end{tabular}

Fonte: IBGE - PNADs de 1981 a 2001

${ }^{(1)}$ Calculado considerando todos os domicílios com declaração de rendimento

${ }^{(2)}$ Considerando apenas domicílios com rendimento positivo.

Esta estabilidade da desigualdade tem atravessado os mais variados ciclos institucionais, políticos e econômicos da história recente do país. Observa-se que os 50\% mais pobres perceberam entre $10,7 \%$ e $13,2 \%$ da renda, enquanto os $10 \%$ mais ricos perceberam entre $45,6 \%$ e $53 \%$ da renda total. 
No período analisado, as pessoas que se encontram entre os $5 \%$ mais ricos se apropriam de aproximadamente $34,5 \%$ do total da renda e os $1 \%$ mais ricos ficam com $14,2 \%$ do total. Em 2001, a razão entre a renda total dos $5 \%$ mais ricos e a renda total dos $50 \%$ mais pobres foi de 2,7 e entre a renda total dos $1 \%$ mais ricos e a renda total dos $40 \%$ mais pobres foi de 1,7 .

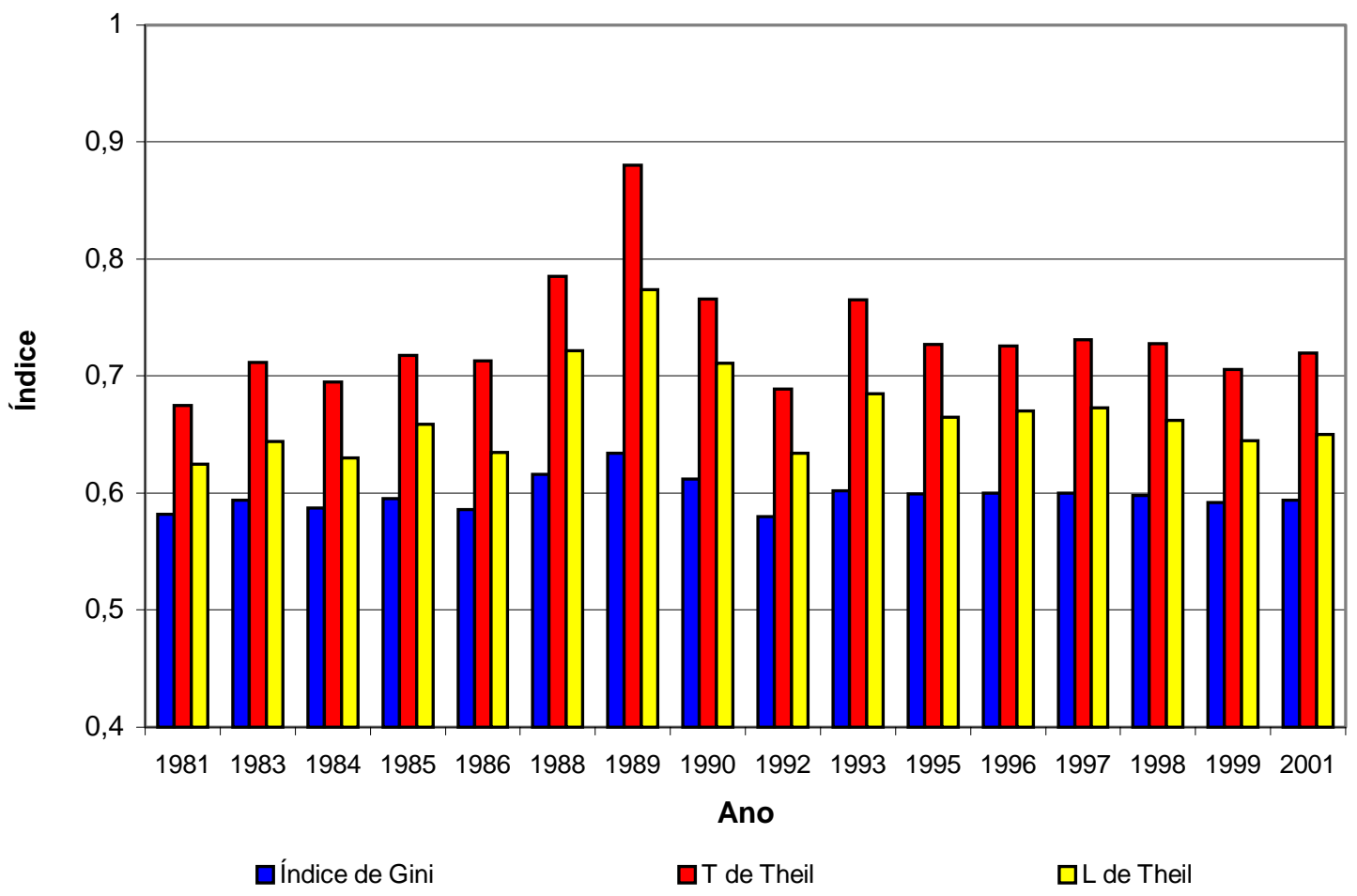

Figura 4 - Índice de Gini, T de Theil e L de Theil. Brasil, 1981 a 2001

Verifica-se que o percentual de renda recebido pelos mais pobres nos últimos sete anos é praticamente o mesmo, e que o percentual recebido pelos mais ricos também apresentou comportamento semelhante. Observa-se que, em matéria de distribuição de renda, o país apresenta uma indesejável estabilidade. 


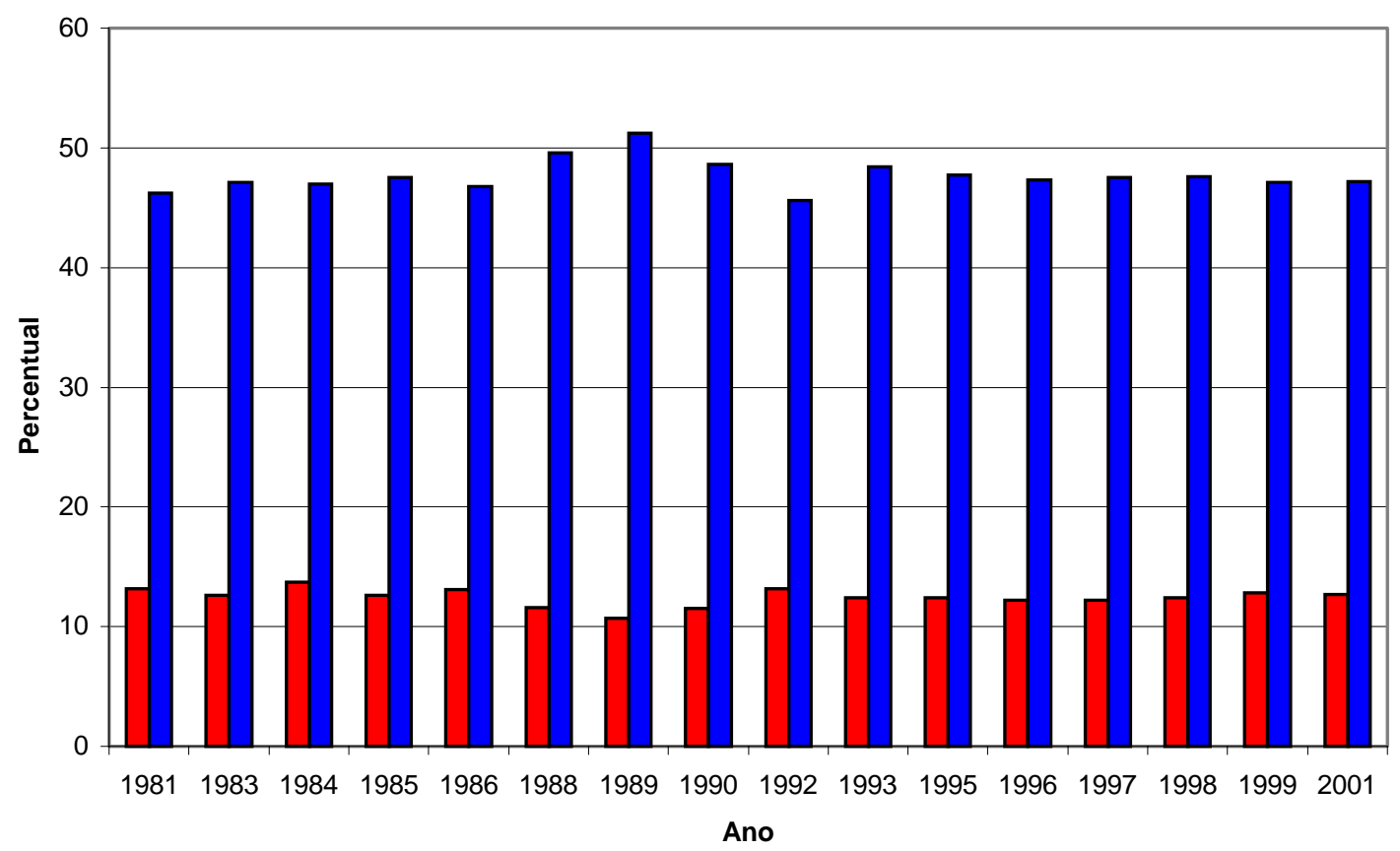

$\square 50 \%$ mais pobres $\square 10 \%$ mais ricos

Figura 5 - Porcentagem da renda total apropriada pelos $50 \%$ mais pobres $\left(50^{-}\right)$e pelos $10 \%$ mais ricos $\left(10^{+}\right)$na distribuição do rendimento domiciliar per capita. Brasil, 1981 a 2001

\subsection{Estratos de rendimento domiciliar per capita}

Nesta seção é feita uma análise tabular considerando 11 estratos de rendimento domiciliar per capita. Para todo o período analisado, foram construídas tabelas que mostram a distribuição dos domicílios, das pessoas e dos componentes do rendimento domiciliar em estratos de rendimento domiciliar per capita. Neste trabalho são apresentadas apenas as tabelas referentes aos anos de 1981 e 2001. Em seguida, apresentam-se os resultados agregados para todo o período, divididos em três tabelas. A primeira tabela mostra o percentual agregado dos domicílios, das pessoas, do rendimento total e dos componentes do rendimento domiciliar per capita que recebem até um salário mínimo; a segunda, para 
aqueles que recebem mais de três salários mínimos e a terceira, para os que recebem mais de oito salários mínimos.

\subsubsection{Distribuição do rendimento domiciliar per capita em 11 estratos, para o Brasil em 1981 e 2001}

Nesta seção, é feita uma análise tabular, considerando 11 estratos de rendimento domiciliar per capita. A estratificação está baseada no salário mínimo (SM) corrente. O primeiro estrato inclui os domicílios cujo rendimento declarado é igual a zero. Ressalte-se que os domicílios com rendimento não declarado foram eliminados da análise.

Os componentes do rendimento domiciliar per capita são formados pelo trabalho principal, outros trabalhos, todos os trabalhos, aposentadorias e pensões, outros rendimentos, aposentadorias e pensões separadamente, aluguéis e juros, dividendos etc para todo o período analisado, ou seja, de 1981 a 2001.

A Tabela 8 mostra a distribuição dos domicílios particulares permanentes e das respectivas pessoas nesses 11 estratos, o rendimento per capita médio e o percentual do rendimento total para o Brasil em 1981.

A Tabela 9 mostra a distribuição do rendimento de todos os trabalhos, desagregado em duas parcelas: trabalho principal e outros trabalhos. Na mesma tabela, é apresentado o rendimento de aposentadorias e pensões desagregado em duas parcelas, sendo a primeira composta por aposentadorias e a segunda por pensões. Ainda faz parte dessa tabela a distribuição do componente outros rendimentos, composta pelas parcelas de doações, aluguéis, juros, dividendos e outros rendimentos, para o Brasil em 1981.

Verifica-se que os domicílios com rendimento per capita de "mais de zero a meio salário mínimo" (SM) constituem o maior percentual dos estratos, com 37,2\% do total, abrigam $45 \%$ das pessoas e ficam com $11,1 \%$ da renda total. Esses domicílios ficam com 
$11,4 \%$ do total dos rendimentos do trabalho e 12,6\% do rendimento de aposentadorias e pensões. Os domicílios com rendimento per capita de "mais de meio SM até um SM" constituem o segundo maior percentual, com $25,8 \%$ do total, abrigam $25,2 \%$ das pessoas e ficam com $16,4 \%$ da renda total. Esses domicílios recebem 16,9\% do total de rendimentos de todos os trabalhos e $15,9 \%$ do rendimento de aposentadorias e pensões.

Tabela 8. Distribuição dos domicílios e das pessoas em estratos de rendimento domiciliar per capita. Brasil, 1981

\begin{tabular}{|c|c|c|c|c|c|c|}
\hline \multirow{2}{*}{$\begin{array}{c}\text { Estrato de } \\
\text { rendimento } \\
\text { domiciliar per } \\
\text { capita, em SM }\end{array}$} & \multicolumn{2}{|c|}{ Domicílios } & \multicolumn{2}{|c|}{ Pessoas } & \multirow{2}{*}{$\begin{array}{c}\text { Rendimento } \\
\text { per capita } \\
\text { médio }{ }^{1} \\
(\mathrm{R} \$)\end{array}$} & \multirow{2}{*}{$\begin{array}{c}\% \text { do } \\
\text { rendimento } \\
\text { total }\end{array}$} \\
\hline & $\mathrm{N}^{\mathrm{o}}\left(10^{3}\right)$ & $\%$ & $\mathrm{~N}^{\mathrm{o}}\left(10^{3}\right)$ & $\%$ & & \\
\hline 0 & 212,3 & 0,8 & 771 & 0,7 & 0 & 0 \\
\hline Mais de 0 a 0,5 & 9614,6 & 37,2 & 53066 & 45,0 & 51,00 & 11,1 \\
\hline Mais de 0,5 a 1 & 6651,9 & 25,8 & 29681 & 25,2 & 122,20 & 16,4 \\
\hline Mais de 1 a 1,5 & 3158,3 & 12,2 & 12821 & 10,9 & 230,26 & 12,1 \\
\hline Mais de 1,5 a 2 & 1733,0 & 6,7 & 6678 & 5,7 & 325,55 & 8,9 \\
\hline Mais de 2 a 2,5 & 1083,8 & 4,2 & 3887 & 3,3 & 419,70 & 6,7 \\
\hline Mais de 2,5 a 3 & 741,6 & 2,9 & 2658 & 2,3 & 517,63 & 5,7 \\
\hline Mais de 3 a 4 & 831,3 & 3,2 & 2855 & 2,4 & 649,51 & 7,6 \\
\hline Mais de 4 a 8 & 1244,7 & 4,8 & 4075 & 3,5 & 1031,04 & 17,3 \\
\hline Mais de 8 a 15 & 406,7 & 1,6 & 1160 & 1,0 & 1951,92 & 9,3 \\
\hline Mais de 15 & 138,1 & 0,5 & 284 & 0,2 & 4190,04 & 4,9 \\
\hline Total & 25816,3 & 100,0 & 117936 & 100,0 & 206,38 & 100,0 \\
\hline
\end{tabular}

Fonte: IBGE - PNAD de 1981

${ }^{1}$ em Reais de setembro de 2001, utilizando como deflator o INPC-IBGE.

Considerando os estratos de "zero a um SM", têm-se 63,8\% dos domicílios com $70,9 \%$ das pessoas recebendo $27,5 \%$ da renda. Esse grupo dos relativamente pobres fica com $28,8 \%$ do rendimento do trabalho principal e $28,5 \%$ do rendimento de aposentadorias e pensões.

Contrastando com os relativamente pobres, os estratos acima de "oito SM"constituem 2,1\% dos domicílios, abrigam 1,2\% das pessoas, mas ficam com $14,2 \%$ da renda total. Verifica-se que ficam com $13,2 \%$ do total dos rendimentos do trabalho e $14,8 \%$ do rendimento de aposentadorias e pensões. Note-se que o rendimento de aposentadorias e 
pensões está mais concentrado nos estratos relativamente ricos do que o rendimento de todas as fontes, com concentração ainda maior no caso das aposentadorias.

Tabela 9. Distribuição de componentes do rendimento domiciliar em estratos de rendimento domiciliar per capita. Brasil, 1981

\begin{tabular}{l|c|c|c|c|c|c|c}
\hline \multirow{2}{*}{$\begin{array}{c}\text { Estrato de } \\
\text { rendimento } \\
\text { domiciliar per } \\
\text { capita em SM }\end{array}$} & $\begin{array}{c}7 \\
\text { Todos os } \\
\text { trabalhos }\end{array}$ & $\begin{array}{c}\text { Trabalho } \\
\text { principal }\end{array}$ & $\begin{array}{c}\text { Outros } \\
\text { trabalhos }\end{array}$ & $\begin{array}{c}\text { Aposenta- } \\
\text { dorias e } \\
\text { pensões }\end{array}$ & $\begin{array}{c}\text { Aposenta- } \\
\text { dorias }\end{array}$ & Pensões & $\begin{array}{c}\text { Outros } \\
\text { rendimentos }\end{array}$ \\
\cline { 2 - 8 } 0 & 0 & 0 & 0 & 0 & 0 & 0 & 0 \\
Mais de 0 a 0,5 & 11,4 & 11,6 & 5,2 & 12,6 & 12,9 & 11,7 & 4,1 \\
Mais de 0,5 a 1 & 16,9 & 17,2 & 7,1 & 15,9 & 15,4 & 18,4 & 8,3 \\
Mais de 1 a 1,5 & 12,5 & 12,7 & 6,5 & 11,1 & 10,8 & 12,8 & 8,3 \\
Mais de 1,5 a 2 & 9,1 & 9,2 & 7,1 & 8,4 & 8,3 & 9,0 & 7,2 \\
Mais de 2 a 2,5 & 6,8 & 6,8 & 5,2 & 6,6 & 6,5 & 7,0 & 6,1 \\
Mais de 2,5 a 3 & 5,7 & 5,8 & 5,3 & 4,9 & 4,8 & 5,8 & 5,4 \\
Mais de 3 a 4 & 7,5 & 7,5 & 8,7 & 8,1 & 8,2 & 7,4 & 8,3 \\
Mais de 4 a 8 & 16,9 & 16,7 & 24,7 & 17,5 & 18,0 & 15,4 & 22,4 \\
Mais de 8 a 15 & 8,9 & 8,6 & 20,5 & 9,5 & 9,8 & 7,9 & 15,4 \\
Mais de 15 & 4,3 & 4,1 & 9,9 & 5,3 & 5,5 & 4,6 & 14,4 \\
Total & $\mathbf{1 0 0 , 0}$ & $\mathbf{1 0 0 , 0}$ & $\mathbf{1 0 0 , 0}$ & $\mathbf{1 0 0 , 0}$ & $\mathbf{1 0 0 , 0}$ & $\mathbf{1 0 0 , 0}$ & $\mathbf{1 0 0 , 0}$ \\
\hline
\end{tabular}

Fonte: IBGE - PNAD de 1981

A Tabela 10 mostra as porcentagens nas linhas, isto é, mostra a participação de cada parcela no rendimento total do estrato, no Brasil em 1981. O rendimento do trabalho principal corresponde à maior parte, com $82,7 \%$ no total, tendendo a diminuir com o aumento do rendimento domiciliar per capita. A participação do rendimento de outros trabalhos, por outro lado, tende a aumentar, especialmente nos três estratos mais ricos.

As aposentadorias e pensões têm uma participação relativamente alta no estrato de "mais de zero até meio SM" e elevam as suas participações nos estratos com rendimento domiciliar per capita acima de três SM, destacando a participação de $10,4 \%$ no total de rendimentos para o estrato "mais de quinze SM". 
Tabela 10. Participação dos componentes do rendimento domiciliar conforme estratos de rendimento domiciliar per capita. Brasil, 1981

\begin{tabular}{lcccccc}
\hline \multirow{2}{*}{$\begin{array}{c}\text { Estrato de rendimento } \\
\text { domiciliar per capita em SM }\end{array}$} & $\begin{array}{c}\text { Trabalho } \\
\text { principal }\end{array}$ & $\begin{array}{c}\text { Outros } \\
\text { trabalhos }\end{array}$ & $\begin{array}{c}\text { Aposenta- } \\
\text { dorias e } \\
\text { pensões }\end{array}$ & $\begin{array}{c}\text { Aposenta- } \\
\text { dorias }\end{array}$ & Pensões & $\begin{array}{c}\text { Outros rendi- } \\
\text { mentos }\end{array}$ \\
\hline 0 & 0 & 0 & 0 & 0 & 0 & 0 \\
Mais de 0 a 0,5 & 86,1 & 1,2 & 10,8 & 8,9 & 1,9 & 1,9 \\
Mais de 0,5 a 1 & 87,0 & 1,1 & 9,3 & 7,2 & 2,0 & 2,6 \\
Mais de 1 a 1,5 & 86,3 & 1,4 & 8,8 & 6,8 & 1,9 & 3,5 \\
Mais de 1,5 a 2 & 84,8 & 2,1 & 9,0 & 7,2 & 1,8 & 4,1 \\
Mais de 2 a 2,5 & 83,9 & 2,0 & 9,4 & 7,5 & 1,9 & 4,7 \\
Mais de 2,5 a 3 & 84,3 & 2,5 & 8,4 & 6,5 & 1,8 & 4,9 \\
Mais de 3 a 4 & 81,3 & 3,0 & 10,1 & 8,3 & 1,7 & 5,6 \\
Mais de 4 a 8 & 79,9 & 3,7 & 9,7 & 8,0 & 1,6 & 6,7 \\
Mais de 8 a 15 & 76,0 & 5,8 & 9,7 & 8,1 & 1,5 & 8,5 \\
Mais de 15 & 69,2 & 5,3 & 10,4 & 8,6 & 1,7 & 15,1 \\
Total & $\mathbf{8 2 , 7}$ & $\mathbf{2 , 6}$ & $\mathbf{9 , 5}$ & $\mathbf{7 , 7}$ & $\mathbf{1 , 8}$ & $\mathbf{5 , 2}$ \\
\hline
\end{tabular}

Fonte: IBGE - PNAD de 1981

As aposentadorias e pensões participam com o segundo maior percentual no total do rendimento, com 9,5\%. Nessa mesma tabela, é realizada a desagregação desse componente em duas parcelas, para que se possa detalhar as suas participações individuais. Agregando o rendimento de todos os trabalhos e as aposentadorias e pensões, tem-se 94,8\% do total. Os outros rendimentos, que incluem doações, aluguéis, juros, dividendos, etc, constituem $5,2 \%$ do total.

A Tabela 11 mostra a distribuição dos domicílios particulares permanentes e das respectivas pessoas, o rendimento per capita em cada estrato e a sua participação no rendimento total declarado, para o Brasil em 2001.

A Tabela 12 mostra a distribuição do rendimento de todos os trabalhos, desagregado em duas parcelas: trabalho principal e outros trabalhos. Na mesma tabela, é apresentado o rendimento de aposentadorias e pensões desagregado em 2 parcelas, sendo a primeira composta por aposentadorias e a segunda por pensões. Ainda faz parte dessa tabela a 
distribuição do componente "outros rendimentos", composta pelas parcelas de doações, aluguéis, juros, dividendos e outros rendimentos, para o Brasil em 2001.

Tabela 11 . Distribuição dos domicílios e das pessoas em estratos de rendimento domiciliar per capita. Brasil, 2001

\begin{tabular}{|c|c|c|c|c|c|c|}
\hline \multirow{2}{*}{$\begin{array}{c}\text { Estrato de } \\
\text { rendimento } \\
\text { domiciliar per } \\
\text { capita, em SM }\end{array}$} & \multicolumn{2}{|c|}{ Domicílios } & \multicolumn{2}{|c|}{ Pessoas } & \multirow{2}{*}{$\begin{array}{l}\text { Rendimento } \\
\text { per capita } \\
\text { médio }{ }^{1} \\
(\mathrm{R} \$)\end{array}$} & \multirow{2}{*}{$\begin{array}{c}\% \text { do } \\
\text { rendiment } \\
\text { total }\end{array}$} \\
\hline & $\mathrm{N}^{\mathrm{o}}\left(10^{3}\right)$ & $\%$ & $\mathrm{~N}^{\mathrm{o}}\left(10^{3}\right)$ & $\%$ & & \\
\hline 0 & 810,4 & 1,8 & 2575 & 1,6 & 0 & 0 \\
\hline Mais de 0 a 0,5 & 10679,9 & 23,5 & 49904 & 30,3 & 53,00 & 5,4 \\
\hline Mais de 0,5 a 1 & 11460,3 & 25,2 & 42081 & 25,6 & 133,90 & 11,5 \\
\hline Mais de 1 a 1,5 & 6656,8 & 14,6 & 22769 & 13,8 & 221,93 & 10,3 \\
\hline Mais de 1,5 a 2 & 4121,6 & 9,1 & 12955 & 7,9 & 313,29 & 8,3 \\
\hline Mais de 2 a 2,5 & 2678,0 & 5,9 & 8404 & 5,1 & 403,63 & 6,9 \\
\hline Mais de 2,5 a 3 & 1722,1 & 3,8 & 5288 & 3,2 & 495,71 & 5,4 \\
\hline Mais de 3 a 4 & 2187,1 & 4,8 & 6671 & 4,1 & 622,58 & 8,5 \\
\hline Mais de 4 a 8 & 3260,4 & 7,2 & 9336 & 5,7 & 987,25 & 18,8 \\
\hline Mais de 8 a 15 & 1273,9 & 2,8 & 3264 & 2,0 & 1908,52 & 12,7 \\
\hline Mais de 15 & 637,5 & 1,4 & 1343 & 0,8 & 4440,12 & 12,2 \\
\hline Total & 45488,0 & 100,0 & 164590 & 100,0 & 297,12 & 100,0 \\
\hline
\end{tabular}

Fonte: IBGE - PNAD de 2001

1 em reais de setembro de 2001.

Observa-se que os domicílios com rendimento per capita de "meio a um SM" constituem o maior percentual dos estratos, com 25,2\% do total, abrigam 25,6\% das pessoas e ficam com 11,5\% da renda. Esses domicílios recebem 11,5\% do total de rendimentos de todos os trabalhos e $12,4 \%$ do rendimento de aposentadorias e pensões. Os domicílios com “mais de zero a meio salário mínimo"constituem o segundo maior percentual, com 23,5\% do total, abrigam o maior percentual de pessoas nos estratos, com 30,3\% e ficam com o menor percentual da renda $(5,4 \%)$. Comparativamente, o estrato com "mais de 15 SM" é composto de $1,4 \%$ dos domicílios, abriga $0,8 \%$ das pessoas e fica com 12,2\% da renda. Esses domicílios recebem $11,8 \%$ do total de rendimentos de todos os trabalhos e $12,1 \%$ do rendimento de aposentadorias e pensões. 
Observa-se, na Tabela 12, que o rendimento das aposentadorias e pensões está concentrado nos estratos relativamente ricos, superando os percentuais do rendimento de todos os trabalhos. Nos estratos inferiores, onde estão localizados os relativamente mais pobres, observa-se que as aposentadorias e pensões se destacam no estrato de "mais de meio a um SM".

Analisando aposentadorias e pensões separadamente, observa-se que nos estratos inferiores (relativamente pobres) é maior o percentual de rendimento de pensões, enquanto nos estratos superiores (relativamente ricos) a predominância é do rendimento das aposentadorias, embora o percentual do rendimento de pensões também seja elevado. Observa-se que o rendimento das aposentadorias está mais concentrado nos estratos relativamente ricos do que o rendimento de todas as fontes.

Tabela 12. Distribuição de componentes do rendimento domiciliar em estratos de rendimento domiciliar per capita. Brasil, 2001

\begin{tabular}{l|c|c|c|c|c|c|c}
\hline \multirow{2}{*}{$\begin{array}{c}\text { Estrato de } \\
\text { rendimento } \\
\text { domiciliar per } \\
\text { capita em SM }\end{array}$} & \multicolumn{7}{c}{ Rendimentos (\%) } \\
\cline { 2 - 8 } & $\begin{array}{c}\text { Todos os } \\
\text { trabalhos }\end{array}$ & $\begin{array}{c}\text { Trabalho } \\
\text { principal }\end{array}$ & $\begin{array}{c}\text { Outros } \\
\text { trabalhos }\end{array}$ & $\begin{array}{c}\text { Aposenta- } \\
\text { dorias e } \\
\text { pensões }\end{array}$ & $\begin{array}{c}\text { Aposenta- } \\
\text { dorias }\end{array}$ & Pensões & $\begin{array}{c}\text { Outros } \\
\text { rendimentos }\end{array}$ \\
\hline 0 & 0 & 0 & 0 & 0 & 0 & 0 & 0 \\
Mais de 0 a 0,5 & 5,4 & 5,5 & 2,4 & 5,0 & 4,7 & 5,9 & 7,5 \\
Mais de 0,5 a 1 & 11,5 & 11,8 & 4,2 & 12,4 & 12,3 & 13,6 & 6,8 \\
Mais de 1 a 1,5 & 10,7 & 10,9 & 4,3 & 9,7 & 9,5 & 10,8 & 6,4 \\
Mais de 1,5 a 2 & 8,4 & 8,6 & 4,9 & 8,4 & 8,1 & 9,7 & 5,3 \\
Mais de 2 a 2,5 & 7,0 & 7,1 & 5,0 & 6,7 & 6,6 & 7,5 & 5,5 \\
Mais de 2,5 a 3 & 5,5 & 5,6 & 3,6 & 4,9 & 4,9 & 5,3 & 4,6 \\
Mais de 3 a 4 & 8,5 & 8,5 & 8,0 & 8,8 & 8,9 & 8,9 & 7,3 \\
Mais de 4 a 8 & 18,7 & 18,6 & 21,5 & 19,0 & 19,5 & 16,8 & 20,3 \\
Mais de 8 a 15 & 12,6 & 12,2 & 21,7 & 13,0 & 13,4 & 10,7 & 14,6 \\
Mais de 15 & 11,8 & 11,2 & 24,3 & 12,1 & 12,2 & 10,9 & 21,7 \\
Total & $\mathbf{1 0 0 , 0}$ & $\mathbf{1 0 0 , 0}$ & $\mathbf{1 0 0 , 0}$ & $\mathbf{1 0 0 , 0}$ & $\mathbf{1 0 0 , 0}$ & $\mathbf{1 0 0 , 0}$ & $\mathbf{1 0 0 , 0}$ \\
\hline
\end{tabular}

Fonte: IBGE - PNAD de 2001 
A Tabela 13 mostra a participação de cada componente do rendimento no rendimento total do estrato, no Brasil em 2001. O rendimento do trabalho principal corresponde à maior parcela, com $74,2 \%$ no total.

As aposentadorias e pensões são a segunda maior parcela, com 18,5\%. Nessa mesma tabela, é realizada a desagregação desse componente em duas parcelas, para que se possa detalhar as suas participações individuais.

Observa-se que a participação das aposentadorias e pensões em cada estrato é significativa e relativamente constante. Separadamente, as aposentadorias participam com um percentual superior ao das pensões no rendimento total. Agregando o rendimento de todos os trabalhos e as aposentadorias e pensões, têm-se 95,9\% do total. Os outros rendimentos constituem $4,1 \%$ do total.

Tabela 13. Participação dos componentes do rendimento domiciliar conforme estratos de rendimento domiciliar per capita. Brasil, 2001

\begin{tabular}{|c|c|c|c|c|c|c|}
\hline \multirow{2}{*}{$\begin{array}{c}\text { Estrato de } \\
\text { rendimento } \\
\text { domiciliar per capita } \\
\text { em SM }\end{array}$} & \multicolumn{6}{|c|}{ Participação (\%) do rendimento } \\
\hline & $\begin{array}{l}\text { Trabalho } \\
\text { principal }\end{array}$ & $\begin{array}{l}\text { Outros } \\
\text { trabalhos }\end{array}$ & $\begin{array}{l}\text { Aposent. e } \\
\text { pensões }\end{array}$ & $\begin{array}{l}\text { Aposen- } \\
\text { tadorias }\end{array}$ & Pensões & $\begin{array}{l}\text { Outros } \\
\text { Rendi- } \\
\text { mentos }\end{array}$ \\
\hline 0 & 0 & 0 & 0 & 0 & 0 & 0 \\
\hline Mais de 0 a 0,5 & 76,4 & 1,5 & 17,2 & 11,5 & 4,1 & 4,9 \\
\hline Mais de 0,5 a 1 & 76,7 & 1,2 & 20,0 & 14,3 & 4,4 & 2,1 \\
\hline Mais de 1 a 1,5 & 79,1 & 1,3 & 17,4 & 12,3 & 3,9 & 2,2 \\
\hline Mais de 1,5 a 2 & 77,2 & 1,9 & 18,7 & 13,1 & 4,4 & 2,2 \\
\hline Mais de 2 a 2,5 & 77,0 & 2,3 & 17,9 & 12,7 & 4,1 & 2,8 \\
\hline Mais de 2,5 a 3 & 77,8 & 2,2 & 17,0 & 12,2 & 3,7 & 3,0 \\
\hline Mais de 3 a 4 & 74,7 & 3,0 & 19,2 & 14,0 & 3,9 & 3,0 \\
\hline Mais de 4 a 8 & 73,8 & 3,7 & 18,7 & 13,8 & 3,4 & 3,8 \\
\hline Mais de 8 a 15 & 71,4 & 5,5 & 19,0 & 14,0 & 3,2 & 4,0 \\
\hline Mais de 15 & 68,3 & 6,4 & 18,5 & 13,3 & 3,4 & 6,3 \\
\hline Total & 74,2 & 3,2 & 18,5 & 13,4 & 3,8 & 4,1 \\
\hline
\end{tabular}

Fonte: IBGE - PNAD de 2001

Na Figura 6, observa-se que a participação do rendimento do trabalho principal em 2001 diminuiu significativamente em relação a 1981, passando de 82,7\% em 1981 
para 74,2\% em 2001. Já a participação do rendimento das aposentadorias e pensões teve um crescimento significativo, passando de 9,5\% em 1981 para 18,5\% em 2001. Na Figura 7, observa-se que, separadamente, tanto a participação das aposentadorias quanto a participação das pensões cresceram. A primeira passou de 7,7\% em 1981 para 13,4\% em 2001 e a última passou de 1,8\% em 1981 para 3,8\% em 2001.

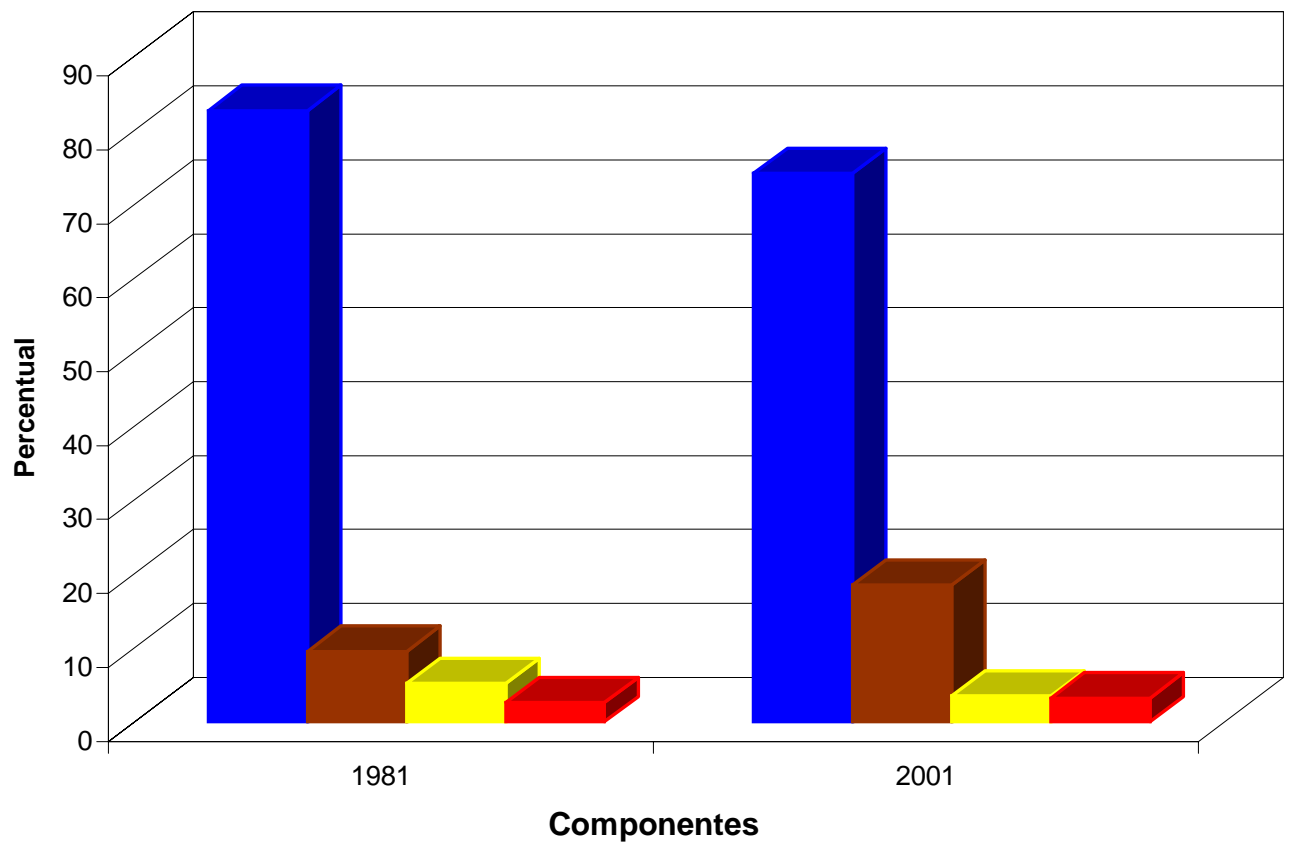

Trabalho principal Aposentadorias e pensões Outros rendimentos $\quad$ Outros trabalhos

Figura 6 - Participação total dos componentes do rendimento domiciliar per capita. Brasil, 1981 e 2001 


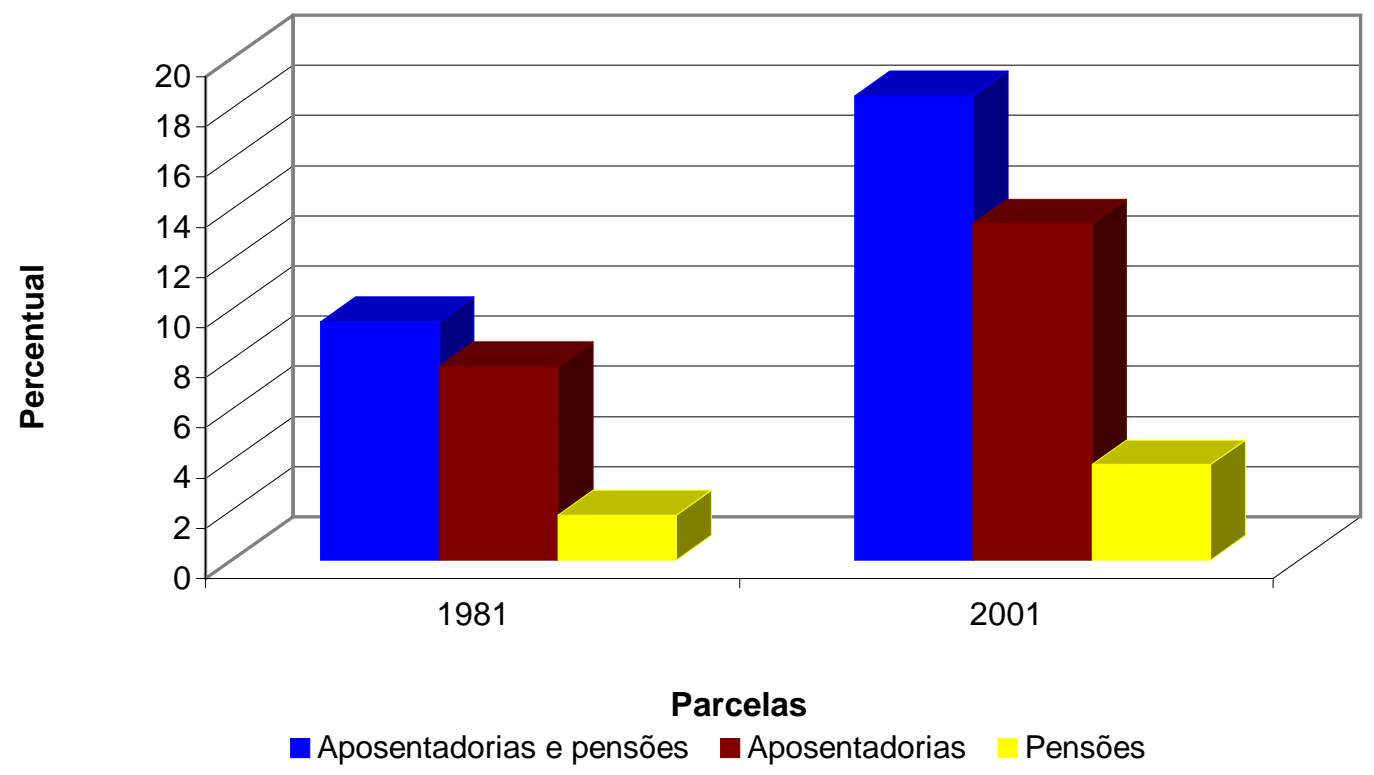

Figura 7 - Participação das parcelas desagregadas de aposentadorias e pensões. Brasil, 1981 e 2001

\subsubsection{Estratos de rendimento domiciliar per capita agregados}

A partir da estratificação do rendimento domiciliar per capita apresentada na seção anterior, apresentam-se três tabelas com resultados. Em cada uma dessas tabelas, juntaram-se estratos com o mesmo número de salários mínimos no período de 1981 a 2001. A Tabela 14 mostra o percentual agregado e a sua média para os domicílios, pessoas, rendimento total e os componentes do rendimento domiciliar per capita, para aqueles que recebem até um salário mínimo.

A razão de tomar como base de comparação um salário mínimo para aposentadorias e pensões é que este valor, ao longo dos anos, e principalmente a partir de 1992, tornou-se muito comum. Estão neste estrato os domicílios que só têm aposentados, cada um recebendo um salário mínimo. Verifica-se que, ao longo do período analisado, geralmente mais de 50\% dos domicílios recebiam até um salário mínimo per capita. 
Tabela 14. Percentual dos domicílios, das pessoas, do rendimento total, e dos componentes do rendimento domiciliar correspondente ao estrato dos que recebem até 1 salário mínimo per capita. Brasil, 1981 a 2001

\begin{tabular}{|c|c|c|c|c|c|c|c|c|c|c|}
\hline \multirow[b]{2}{*}{ ANO } & \multicolumn{3}{|c|}{$\%$} & \multicolumn{7}{|c|}{$\begin{array}{l}\text { Componentes do rendimento domiciliar per capita acumulados em } \\
\text { percentual }\end{array}$} \\
\hline & $\begin{array}{l}\text { Domi } \\
\text { cílios }\end{array}$ & Pessoas & $\begin{array}{c}\text { Rendi } \\
\text { mento } \\
\text { total }\end{array}$ & $\begin{array}{c}\text { Todos os } \\
\text { traba- } \\
\text { lhos }\end{array}$ & $\begin{array}{l}\text { Trabalho } \\
\text { principal }\end{array}$ & $\begin{array}{c}\text { Outros } \\
\text { trabalhos }\end{array}$ & $\begin{array}{c}\text { Aposen- } \\
\text { tadoria e } \\
\text { pensão }\end{array}$ & $\begin{array}{l}\text { Aposen- } \\
\text { tadoria }\end{array}$ & Pensão & $\begin{array}{l}\text { Outros } \\
\text { rendi- } \\
\text { mentos }\end{array}$ \\
\hline 1981 & 63,8 & 70,9 & 27,5 & 28,3 & 28,8 & 12,3 & 28,5 & 28,3 & 30,1 & 12,4 \\
\hline 1983 & 62,9 & 69,8 & 25,6 & 26,3 & 26,8 & 13,0 & 24,3 & 23,1 & 29,8 & 16,0 \\
\hline 1984 & 61,6 & 68,6 & 25,1 & 25,6 & 26,2 & 10,0 & 25,0 & 24,3 & 28,4 & 17,6 \\
\hline 1985 & 58,5 & 65,4 & 22,0 & 22,2 & 22,8 & 8,5 & 22,1 & 21,5 & 25,3 & 16,8 \\
\hline 1986 & 52,3 & 58,9 & 18,2 & 18,2 & 18,7 & 6,1 & 20,2 & 19,5 & 23,4 & 12,0 \\
\hline 1988 & 57,1 & 63,8 & 19,4 & 19,4 & 19,7 & 8,6 & 22,8 & 22,0 & 27,0 & 13,5 \\
\hline 1989 & 51,5 & 57,9 & 14,6 & 14,8 & 15,1 & 5,6 & 16,6 & 15,5 & 21,0 & 8,2 \\
\hline 1990 & 46,3 & 52,1 & 12,6 & 12,8 & 13,1 & 5,0 & 13,0 & 12,4 & 15,4 & 7,5 \\
\hline 1992 & 59,1 & 65,9 & 23,8 & 24,3 & 24,7 & 10,9 & 24,9 & 23,7 & 31,2 & 10,9 \\
\hline 1993 & 55,4 & 62,1 & 19,6 & 19,6 & 20,0 & 9,5 & 22,8 & 22,5 & 27,7 & 7,8 \\
\hline 1995 & 44,5 & 51,1 & 12,9 & 12,9 & 13,1 & 6,3 & 15,0 & 14,6 & 17,3 & 6,9 \\
\hline 1996 & 43,1 & 49,2 & 11,8 & 11,6 & 11,9 & 4,9 & 14,6 & 14,6 & 16,4 & 5,6 \\
\hline 1997 & 44,9 & 50,9 & 12,7 & 12,4 & 12,7 & 6,1 & 15,1 & 15,1 & 16,8 & 7,9 \\
\hline 1998 & 45,9 & 52,2 & 13,5 & 13,5 & 13,7 & 8,0 & 15,0 & 14,5 & 18,0 & 8,6 \\
\hline 1999 & 46,5 & 52,8 & 14,3 & 14,2 & 14,5 & 7,8 & 14,2 & 14,6 & 18,5 & 10,9 \\
\hline 2001 & 50,5 & 57,5 & 16,9 & 16,9 & 17,3 & 6,6 & 17,4 & 17,0 & 19,5 & 14,3 \\
\hline Média & 52,7 & 59,3 & 18,2 & 18,3 & 18,7 & 8,1 & 19,5 & 19,0 & 22,9 & 11,1 \\
\hline
\end{tabular}

Fonte: IBGE - PNADs de 1981 a 2001.

Em 1981, verifica-se que os domicílios com rendimento per capita de "até um salário mínimo" constituem $63,8 \%$ do total e contêm 70,9\% das pessoas que recebem $27,5 \%$ da renda. Esse grupo ficou com 28,3\% do total dos rendimentos de todos os trabalhos; $28,5 \%$ de aposentadorias e pensões; $28,3 \%$ de aposentadorias e $30,1 \%$ de pensões, quando 
considerados separadamente. Observa-se que a participação do estrato no rendimento das aposentadorias e pensões é ligeiramente superior à sua participação no rendimento de todos os trabalhos e, quando considerado individualmente, existe uma concentração ainda maior no caso das pensões. Esses dados revelam a importância dos rendimentos de aposentadorias e pensões para esse estrato.

Em 1990, os domicílios com rendimento per capita de "até um salário mínimo" constituem $46,3 \%$ do total e contêm $52,1 \%$ das pessoas que recebem $12,6 \%$ da renda, conforme pode ser visto na Tabela 14. Esse grupo fica com 12,8\% do total dos rendimentos do trabalho; $13 \%$ de aposentadorias e pensões; $12,4 \%$ de aposentadorias e 15,4\% de pensões, quando consideradas individualmente. Em 1990 observa-se, também, que a participação do estrato no rendimento das aposentadorias e pensões é ligeiramente superior à sua participação no rendimento de todos os trabalhos e, individualmente, a participação do estrato no rendimento de pensões é superior à sua participação nos rendimentos de aposentadorias e de todos os trabalhos.

No período entre 1981 e 1990, o percentual de domicílios que recebiam até um salário mínimo foi decrescente, o mesmo ocorrendo com o rendimento total. Observa-se também que a participação do estrato no rendimento de todos os trabalhos teve queda ligeiramente superior ao rendimento das aposentadorias e pensões, conforme pode ser visualizado na Figura 8.

Em 2001, os domicílios com rendimento per capita até um salário mínimo constituíram $50,5 \%$ do total e continham $57,5 \%$ das pessoas que recebiam $16,9 \%$ da renda. Esse grupo ficou com 16,9\% do total dos rendimentos do trabalho e 17,4\% do total de aposentadorias e pensões. Observa-se novamente que a participação do estrato no total de rendimento de pensões é maior que no rendimento de aposentadorias. 


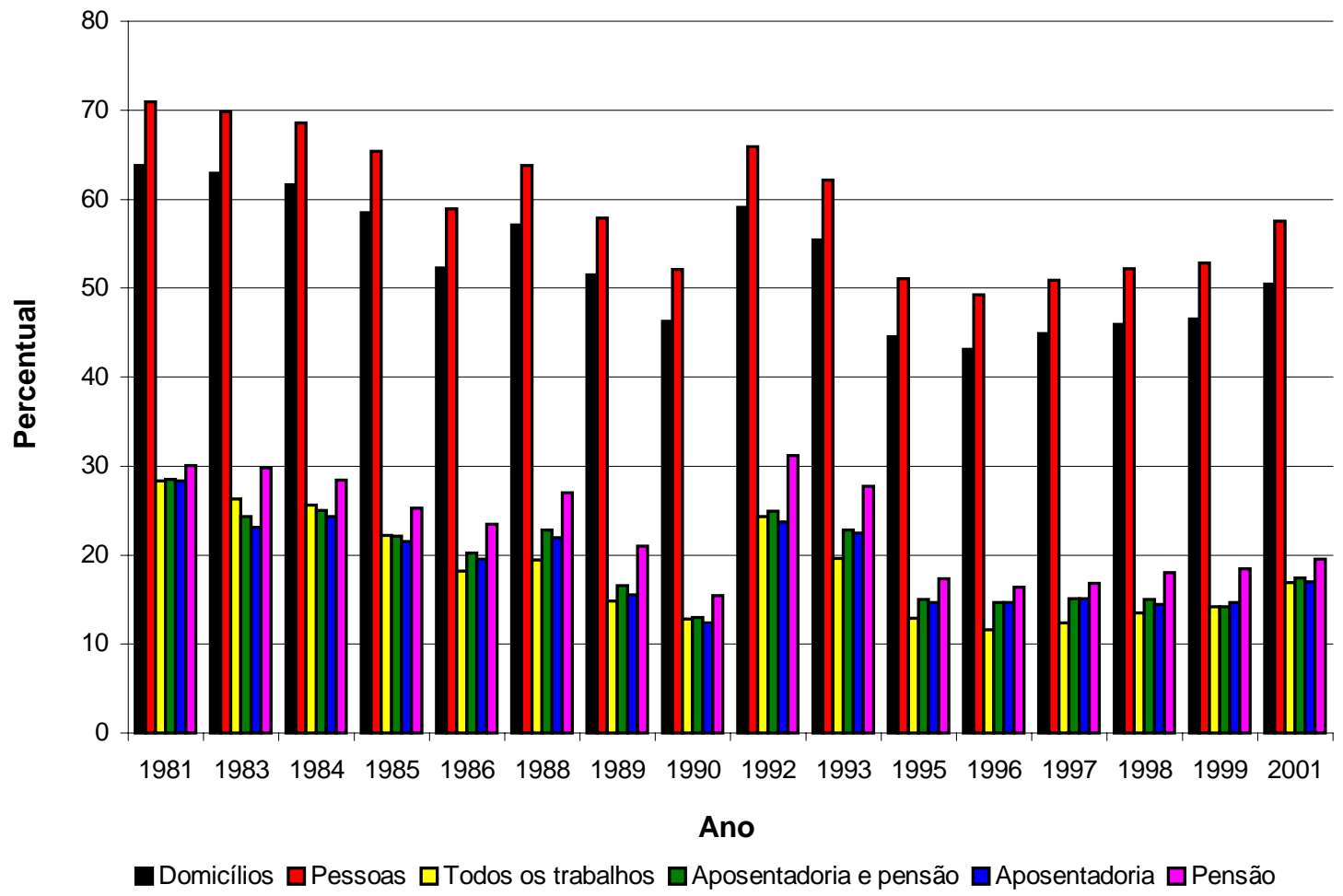

Figura 8 - Percentual dos domicílios, das pessoas, do rendimento de todos os trabalhos, das aposentadorias e pensões, das aposentadorias e das pensões correspondente ao estrato de rendimento domiciliar per capita até 1 salário mínimo. Brasil, 1981 a 2001

Entre 1992 e 1996, observa-se um recuo no percentual de domicílios que recebem até um salário mínimo, voltando a crescer a partir de 1997, conforme mostra a Figura 8. O percentual do rendimento total no estrato diminui ao longo dos anos 90 , voltando a crescer em 1999 e 2001. O percentual de rendimento de todos os trabalhos no estrato teve queda superior ao do rendimento de aposentadorias e pensões.

Em termos gerais, no período de 1981 a 2001, verifica-se que os domicílios com rendimento per capita até um salário mínimo constituem, em média, 52,7\% do total e contêm 59,3\% das pessoas que recebem 18,2\% da renda. Esse grupo fica, em média, com 
$18,3 \%$ do total dos rendimentos do trabalho; $19,5 \%$ de aposentadorias e pensões; $19,0 \%$ de aposentadorias e $22,9 \%$ do rendimento de pensões, quando consideradas separadamente.

A Figura 8 mostra as variações ocorridas nas participações analisadas no período de 1981 a 2001. Essas variações são devidas, em parte, a mudanças no valor real do salário mínimo. É interessante notar que, entre 1981 e 2001, a participação do estrato de até 1 salário mínimo no rendimento das pensões é superior à participação dos rendimentos de todos os trabalhos, de aposentadorias e pensões e de aposentadorias. Isso indica que as pessoas mais pobres ficam com uma participação maior de pensões do que de aposentadorias. Observa-se também que a proporção de domicílios nesse estrato é menor do que a proporção de pessoas, indicando que nos domicílios mais pobres há mais pessoas por domicílio.

A Tabela 15 mostra o percentual agregado e a sua média para os domicílios, pessoas, rendimento total e os componentes do rendimento domiciliar per capita, correspondente ao estrato dos que recebem mais de três salários mínimos.

O valor de três salários mínimos foi adotado porque em 1981, constatou-se que aproximadamente $10 \%$ dos domicílios recebiam mais de três salários mínimos. Ao longo do período analisado essa participação permanece, em geral, abaixo de $20 \%$.

Os domicílios com rendimento per capita acima de três salários mínimos, em 1981, são formados por $10,1 \%$ do total, contêm $7,1 \%$ das pessoas e recebem $39,1 \%$ da renda total. Esse grupo fica com $37,6 \%$ do total dos rendimentos do trabalho; 40,4\% de aposentadorias e pensões; $41,5 \%$ de aposentadorias e 35,3\% de pensões, quando considerados separadamente. Observa-se que a participação do estrato no rendimento de aposentadorias e pensões está mais concentrado do que a sua participação no rendimento de todos os trabalhos, com concentração ainda maior no caso das aposentadorias.

Outra maneira de verificar o grau de concentração da distribuição de rendimento em favor de domicílios com rendimento per capita acima de três salários mínimos é calcular a 
razão entre a participação desse estrato e a participação do estrato dos que recebem até um salário mínimo per capita. Essa razão, para 1981, é 1,3 para o trabalho principal e para o rendimento de todos os trabalhos, 1,4 para aposentadorias e pensões, 4,9 para outros rendimentos, 5,2 para outros trabalhos, 1,5 para aposentadorias e 1,2 para pensões.

Em 1990, os domicílios com rendimentos per capita acima de três salários mínimos constituem $20,8 \%$ do total, contêm $16,5 \%$ das pessoas e recebem $60,3 \%$ da renda total. Esse grupo passou a deter $64,2 \%$ das aposentadorias e pensões, 75,6\% das aposentadorias e $66,3 \%$ das pensões quando consideradas separadamente. Observa-se novamente que a participação do estrato no rendimento de aposentadorias e pensões está mais concentrada do que a sua participação nos rendimentos de todos os trabalhos, com concentração especialmente elevada no caso das aposentadorias.

Em 2001, os domicílios com rendimento per capita acima de três salários mínimos são formados por $16,2 \%$ do total, contêm $12,6 \%$ das pessoas e recebem $52,2 \%$ da renda total. Esse grupo, em 2001, deteve 52,9\% do valor das aposentadorias e pensões e, separadamente, $63,9 \%$ das aposentadorias e 54,0\% das pensões. Novamente, observa-se que a participação do estrato no rendimento de aposentadorias e pensões está mais concentrada do que a sua participação no rendimento de todos os trabalhos, com concentração ainda maior no caso das aposentadorias.

Na década de 90, o grupo que detém rendimento domiciliar per capita de três salários mínimos, ou mais, teve crescimento, passando de 11,2\% em 1992 para 16,2\% em 2001, e o rendimento total em seu poder passou de 41,9\% para 52,2\%. Observa-se que, em 1996, domicílios com rendimentos de três salários mínimos ou mais atingiram o seu maior percentual $(21,7 \%)$, o mesmo acontecendo com o rendimento total $(60,4 \%)$. Nesse período, o percentual de rendimento das aposentadorias e pensões teve crescimento superior ao de todos os trabalhos e, individualmente, a concentração das aposentadorias foi ainda maior, conforme pode ser visto na Figura 9. 
Tabela 15. Percentual dos domicílios, das pessoas, do rendimento total, e dos componentes do rendimento domiciliar correspondente ao estrato dos que recebem mais de 3 salários mínimos per capita. Brasil, 1981 a 2001

\begin{tabular}{|c|c|c|c|c|c|c|c|c|c|c|}
\hline \multirow[b]{2}{*}{ ANO } & \multicolumn{3}{|c|}{$\%$} & \multicolumn{7}{|c|}{$\begin{array}{l}\text { Componentes do rendimento domiciliar per capita } \\
\text { acumulados em percentual }\end{array}$} \\
\hline & $\begin{array}{l}\text { Domi } \\
\text { cílios }\end{array}$ & Pessoas & $\begin{array}{l}\text { Rendi- } \\
\text { mento } \\
\text { total }\end{array}$ & $\begin{array}{c}\text { Todos } \\
\text { os traba- } \\
\text { lhos }\end{array}$ & $\begin{array}{c}\text { Traba- } \\
\text { lho } \\
\text { Princi- } \\
\text { pal }\end{array}$ & $\begin{array}{c}\text { Outros } \\
\text { traba- } \\
\text { lhos }\end{array}$ & $\begin{array}{l}\text { Aposen- } \\
\text { tadoria e } \\
\text { pensão }\end{array}$ & $\begin{array}{l}\text { Aposen- } \\
\text { tadoria }\end{array}$ & Pensão & $\begin{array}{l}\text { Outros } \\
\text { rendi- } \\
\text { mentos }\end{array}$ \\
\hline 1981 & 10,1 & 7,1 & 39,1 & 37,6 & 36,9 & 63,8 & 40,4 & 41,5 & 35,3 & 60,5 \\
\hline 1983 & 11,0 & 7,7 & 41,8 & 40,4 & 39,3 & 68,4 & 44,6 & 46,2 & 36,0 & 57,6 \\
\hline 1984 & 11,5 & 8,1 & 42,9 & 42,1 & 41,0 & 72,0 & 43,0 & 44,2 & 37,2 & 56,4 \\
\hline 1985 & 13,2 & 9,7 & 46,7 & 46,0 & 45,0 & 74,5 & 47,5 & 49,0 & 40,2 & 59,5 \\
\hline 1986 & 15,8 & 11,9 & 50,7 & 50,0 & 48,9 & 77,4 & 49,9 & 51,7 & 41,0 & 66,6 \\
\hline 1988 & 14,1 & 10,7 & 50,9 & 50,6 & 49,6 & 73,1 & 48,5 & 49,9 & 41,3 & 63,7 \\
\hline 1989 & 18,3 & 14,2 & 59,2 & 58,4 & 57,5 & 79,6 & 58,7 & 61,1 & 48,5 & 77,5 \\
\hline 1990 & 20,8 & 16,5 & 60,3 & 59,1 & 58,1 & 81,2 & 64,2 & 66,3 & 56,8 & 75,6 \\
\hline 1992 & 11,2 & 8,3 & 41,9 & 40,5 & 39,6 & 64,5 & 42,0 & 43,8 & 32,3 & 69,0 \\
\hline 1993 & 14,0 & 10,6 & 49,7 & 48,5 & 47,9 & 71,2 & 47,3 & 48,1 & 39,4 & 73,5 \\
\hline 1995 & 20,5 & 16,3 & 58,9 & 58,2 & 57,3 & 79,0 & 58,6 & 59,9 & 51,2 & 75,4 \\
\hline 1996 & 21,7 & 17,4 & 60,4 & 59,7 & 58,9 & 80,4 & 59,8 & 60,7 & 53,8 & 77,4 \\
\hline 1997 & 20,7 & 16,6 & 59,4 & 58,9 & 58,1 & 78,7 & 59,1 & 59,8 & 53,4 & 73,3 \\
\hline 1998 & 19,8 & 15,6 & 58,0 & 57,1 & 56,3 & 77,1 & 58,5 & 59,4 & 52,2 & 73,4 \\
\hline 1999 & 18,7 & 14,7 & 55,9 & 54,8 & 54,1 & 75,1 & 57,4 & 58,9 & 50,3 & 69,9 \\
\hline 2001 & 16,2 & 12,6 & 52,2 & 51,6 & 50,5 & 75,5 & 52,9 & 54,0 & 47,3 & 63,9 \\
\hline Média & 16,1 & 12,4 & 51,8 & 50,8 & 49,9 & 74,5 & 52,0 & 53,4 & 44,8 & 68,3 \\
\hline
\end{tabular}

Fonte: IBGE - PNADs de 1981 a 2001.

Os domicílios com rendimentos per capita acima de três salários mínimos, no período de 1981 a 2001, constituem, em média, 16,1\% do total, contêm 12,4\% das pessoas e recebem 51,8\% da renda total. Esse grupo fica, em média, com 50,8\% do total dos 
rendimentos do trabalho; 52,0\% de aposentadorias e pensões e, considerando separadamente, $53,4 \%$ de aposentadorias e $44,8 \%$ de pensões.

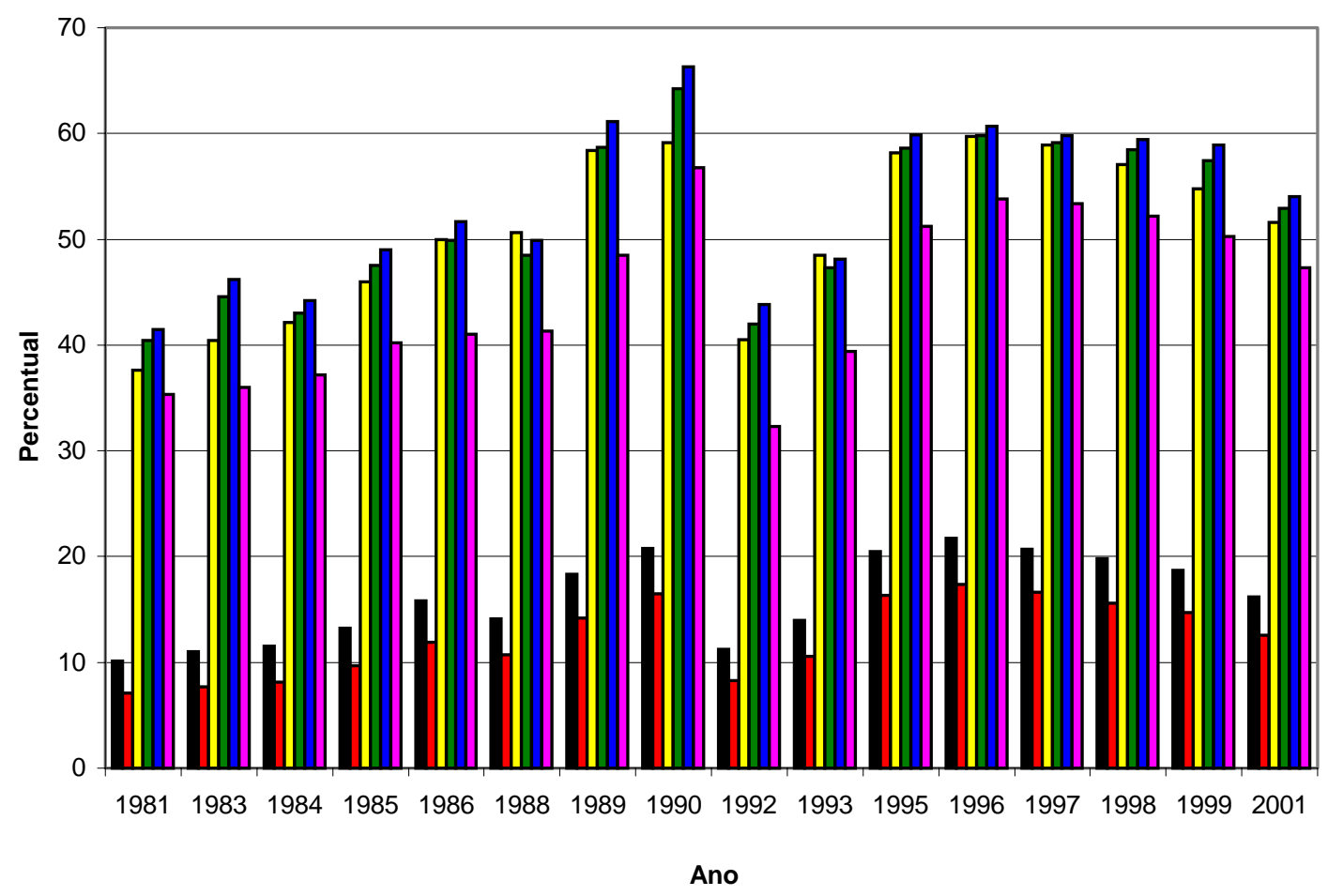

$\square$ Domicílios $\square$ Pessoas $\square$ Todos os trabalhos $\square$ Aposentadorias e pensões $\square$ Aposentadoria $\square$ Pensão

Figura 9 - Percentual dos domicílios, das pessoas, do rendimento de todos os trabalhos, das aposentadorias e pensões, das aposentadorias e das pensões correspondente ao estrato de rendimento domiciliar per capita maior do que 3 salários mínimos. Brasil, 1981 a 2001

Através da Figura 9, pode-se notar que, entre 1981 e 2001, a participação do estrato de rendimento maior do que 3 salários mínimos no rendimento das aposentadorias é quase sempre superior à sua participação nos rendimentos de todos os trabalhos, de aposentadorias e pensões e de pensões separadamente. A proporção de pessoas nesse estrato é menor do que sua participação no número de domicílios, indicando que o número de pessoas é menor nos domicílios mais ricos. 
A razão entre a participação do estrato dos que recebem mais de três salários mínimos e a participação do estrato daqueles com rendimento per capita de até um salário mínimo, para todo o período, em termos médios, é: 2,7 para o rendimento do trabalho principal; 9,4 para o de outros trabalhos; 2,8 para o de todos os trabalhos; 2,7 para o rendimento de aposentadorias e pensões; 6,6 para outros rendimentos; 2,9 para o rendimento de aposentadorias e 2,0 para o rendimento de pensões, 13,3 para os rendimentos de aluguéis e 5,2 para o rendimento de juros, dividendos, etc.

Esses resultados mostram que a concentração em favor do estrato dos que auferem mais de 3 salários mínimos é maior para o rendimento de aposentadorias do que para o rendimento de todos os trabalhos. Observa-se, também, que a concentração é maior para aposentadorias do que para pensões.

A Tabela 16 mostra o percentual agregado e a sua média para os domicílios, pessoas, rendimento total e os componentes do rendimento domiciliar per capita, para o estrato dos que recebem acima de oito salários mínimos per capita.

Os domicílios com rendimento per capita acima de oito SM, em 1981, são formados por $2,1 \%$ do total, contêm $1,2 \%$ das pessoas e recebem $14,2 \%$ da renda total. Ficam com $13,2 \%$ do total dos rendimentos do trabalho; $14,8 \%$ de aposentadorias e pensões; $15,3 \%$ de aposentadorias e $12,5 \%$ de pensões.

No período entre 1981 e 2001, o percentual de domicílios e de pessoas com rendimentos maiores que oito SM foi crescente. Também observa-se um elevado crescimento no percentual do rendimento total, de todos os trabalhos e das aposentadorias e pensões. Verifica-se que a participação desse estrato no rendimento de aposentadorias e pensões está mais concentrado do que a sua participação no rendimento de todos os trabalhos. Para a maioria dos anos analisados, individualmente, a concentração das aposentadorias é ainda maior. 
Note-se que, no período de 1981 a 2001, o grupo de rendimento domiciliar per capita de até um salário mínimo é composto por $52,7 \%$ dos domicílios, em média, e ficou com $18,2 \%$ do rendimento total e com $19,5 \%$ do rendimento de aposentadorias e pensões, enquanto apenas $16,1 \%$ dos domicílios recebem mais de três salários mínimos, mas detêm $51,8 \%$ do rendimento total e 52,0\% das aposentadorias e pensões. O grupo de rendimento domiciliar per capita de mais de oito salários mínimos é composto de 4,2\% dos domicílios, mas fica com $24,5 \%$ do rendimento total e com $24,5 \%$ das aposentadorias e pensões.

Nos dois estratos de rendimento mais elevados (mais do que 3 e mais do que 8 salários mínimos), a participação do estrato no rendimento de aposentadorias e pensões é sistematicamente maior do que a participação do rendimento de todos os trabalhos.

A Figura 10 mostra o comportamento, ao longo do período analisado, das participações dos grupos de "até um SM", "mais de três SM" e "mais de oito SM" no valor total do rendimento de aposentadorias e pensões.

Observa-se que a participação do grupo com até um salário mínimo, de forma geral, decresceu ao longo do tempo, com exceção do início da década de 90. De acordo com Brant (2001), esse comportamento deveu-se ao incremento no número de benefícios, que houve entre 1991 e 1994 (cerca de 56\%) por conta, principalmente, do aumento expressivo de benefícios rurais como resultado das mudanças introduzidas na Constituição Federal de 1988 e regulamentadas em 1991. Os benefícios urbanos e rurais foram equiparados em termos de valor, e os trabalhadores rurais puderam se aposentar com benefício equivalente a um salário mínimo. Para o grupo com mais de três SM, houve crescimento até 1990, decrescendo em 1992 e voltando a crescer a partir daí. Comportamento semelhante verificase para o grupo de mais de oito SM. 
Tabela 16. Percentual dos domicílios, das pessoas, do rendimento total, e dos componentes do rendimento domiciliar correspondente ao estrato dos que recebem mais de 8 salários mínimos per capita. Brasil, 1981 a 2001

\begin{tabular}{|c|c|c|c|c|c|c|c|c|c|c|}
\hline \multirow[b]{2}{*}{ ANO } & \multicolumn{3}{|c|}{$\%$} & \multicolumn{7}{|c|}{$\begin{array}{l}\text { Componentes do rendimento domiciliar per capita } \\
\text { acumulados em percentual }\end{array}$} \\
\hline & $\begin{array}{l}\text { Domi } \\
\text { cílios }\end{array}$ & Pessoas & $\begin{array}{c}\text { Rendi- } \\
\text { mento } \\
\text { total }\end{array}$ & $\begin{array}{c}\text { Todos } \\
\text { os traba- } \\
\text { lhos }\end{array}$ & $\begin{array}{c}\text { Traba- } \\
\text { lho } \\
\text { princi- } \\
\text { pal }\end{array}$ & $\begin{array}{c}\text { Outros } \\
\text { traba- } \\
\text { lhos }\end{array}$ & $\begin{array}{l}\text { Aposen- } \\
\text { tadoria e } \\
\text { pensão }\end{array}$ & $\begin{array}{c}\text { Aposen- } \\
\text { tadoria }\end{array}$ & Pensão & $\begin{array}{l}\text { Outros } \\
\text { rendi- } \\
\text { mentos }\end{array}$ \\
\hline 1981 & 2,1 & 1,2 & 14,2 & 13,2 & 12,7 & 30,4 & 14,8 & 15,3 & 12,5 & 29,8 \\
\hline 1983 & 2,3 & 1,3 & 15,7 & 14,8 & 14,0 & 34,9 & 17,1 & 17,8 & 13,3 & 26,9 \\
\hline 1984 & 2,5 & 1,4 & 16,7 & 15,8 & 15,0 & 38,5 & 16,9 & 17,7 & 13,1 & 30,2 \\
\hline 1985 & 3,0 & 1,9 & 19,6 & 18,9 & 18,0 & 44,2 & 20,5 & 21,6 & 14,8 & 32,3 \\
\hline 1986 & 3,9 & 2,5 & 23,1 & 22,4 & 21,4 & 47,6 & 22,7 & 24,7 & 12,9 & 38,9 \\
\hline 1988 & 3,6 & 2,4 & 24,2 & 23,8 & 23,0 & 42,3 & 22,5 & 23,5 & 17,8 & 36,9 \\
\hline 1989 & 5,4 & 3,7 & 32,2 & 31,1 & 30,2 & 53,0 & 29,6 & 31,6 & 21,0 & 59,2 \\
\hline 1990 & 6,1 & 4,3 & 31,9 & 30,6 & 29,6 & 53,4 & 36,2 & 38,3 & 28,4 & 48,5 \\
\hline 1992 & 2,3 & 1,4 & 16,4 & 15,1 & 14,5 & 32,1 & 16,3 & 17,0 & 12,2 & 42,8 \\
\hline 1993 & 3,5 & 2,3 & 23,6 & 22,8 & 22,0 & 42,4 & 20,7 & 20,2 & 17,7 & 47,3 \\
\hline 1995 & 5,9 & 4,1 & 30,8 & 29,9 & 28,9 & 53,3 & 31,2 & 31,9 & 26,3 & 48,9 \\
\hline 1996 & 6,2 & 4,3 & 31,2 & 30,5 & 29,4 & 55,2 & 31,1 & 31,5 & 26,3 & 48,9 \\
\hline 1997 & 5,9 & 4,1 & 30,6 & 30,2 & 29,3 & 51,9 & 29,3 & 29,5 & 25,9 & 46,1 \\
\hline 1998 & 5,4 & 3,7 & 29,3 & 28,4 & 27,5 & 51,7 & 29,4 & 30,4 & 22,9 & 47,3 \\
\hline 1999 & 5,2 & 3,6 & 28,1 & 27,0 & 26,3 & 47,0 & 29,3 & 30,8 & 23,0 & 44,3 \\
\hline 2001 & 4,2 & 2,8 & 24,9 & 24,4 & 23,4 & 46,0 & 25,1 & 25,6 & 21,6 & 36,3 \\
\hline Média & 4,2 & 2,8 & 24,5 & 23,7 & 22,8 & 45,2 & 24,5 & 25,5 & 19,4 & 41,5 \\
\hline
\end{tabular}

Fonte: IBGE - PNADs de 1981 a 2001.

De acordo com Brant (2001a), após a promulgação da Constituição de 1988 houve uma expansão da política previdenciária, mediante aumento expressivo na quantidade de beneficiários e aumento do valor médio dos benefícios, resultado da estabilização de preços 
e de reajustes anuais, implementadas a partir de 1994. Entre 1988 e 2000, o valor médio dos benefícios pagos pela previdência aumentou, em termos reais, 60,9\%. O resultado dessa política, segundo Brant, foi a elevação da renda per capita dos aposentados no período, que subiu cerca de 30\% entre 1992 e 1999, enquanto a renda per capita média das famílias que não têm beneficiários da previdência apresentou um incremento de $23 \%$.

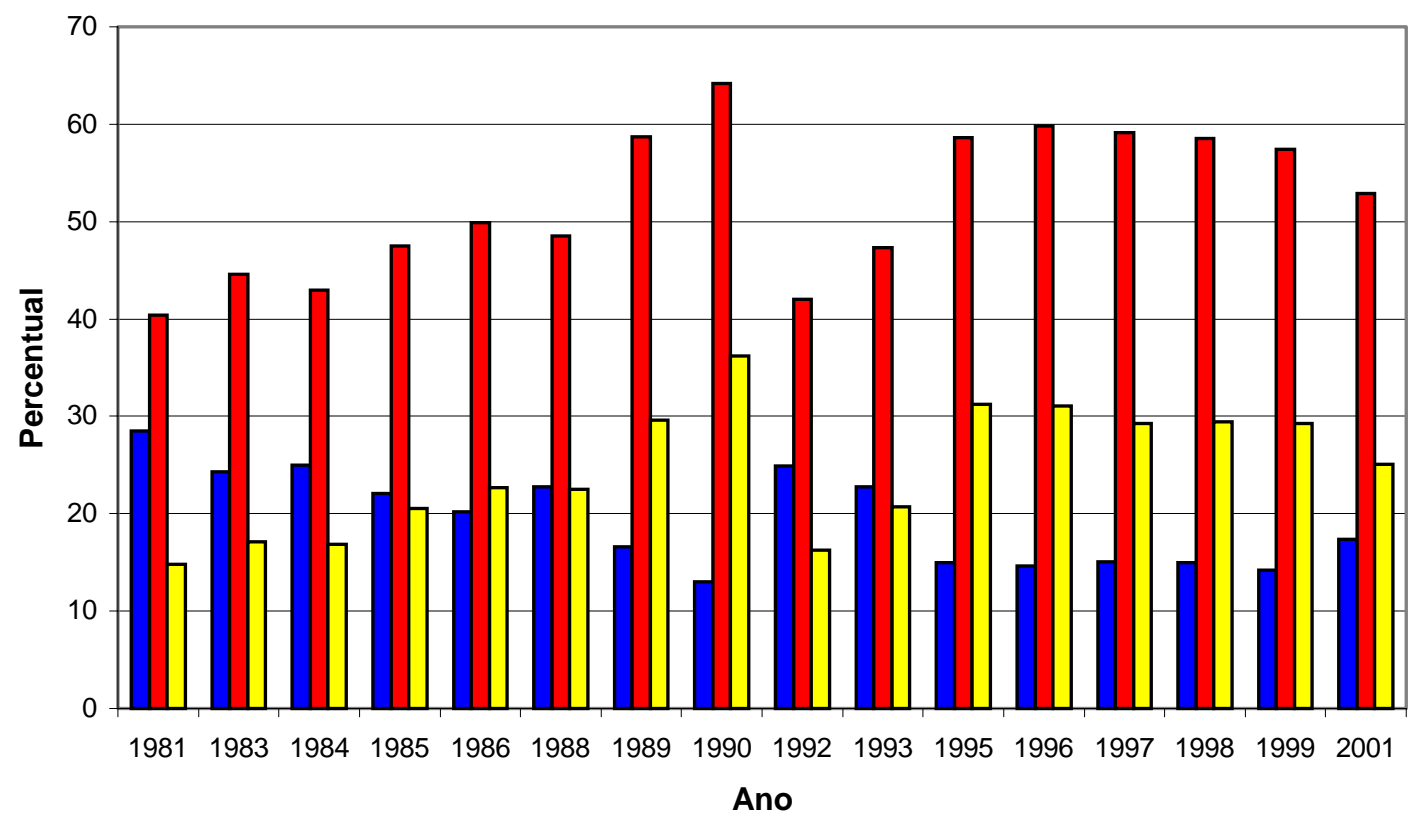

$\square$ Aposentadorias e pensões de até 1 SM $\square$ Aposentadorias e pensões mais de 3 SM $\square$ Aposentadorias e pensões mais de 8 SM

Figura 10 - Distribuição percentual do rendimento das aposentadorias e pensões para os estratos agregados de até 1 salário mínimo, com mais de 3 salários mínimos e com mais de 8 salários mínimos. Brasil, 1981 a 2001 


\subsection{Decomposição do índice de Gini}

Com a utilização da metodologia de decomposição do índice de Gini conforme parcelas do rendimento domiciliar per capita, pode-se observar a participação de cada componente na formação do Gini global, para cada ano analisado. Especial atenção é dada ao rendimento das aposentadorias e pensões, objeto de estudo neste trabalho.

A Tabela 17 mostra a decomposição do valor médio (VM) e a participação percentual $\left[(\%) \phi_{k}\right]$ dos componentes do rendimento domiciliar per capita.

Observa-se que os rendimentos do trabalho principal contribuem com a maior parcela no total dos rendimentos, embora tenha diminuído sua participação a partir de 1989. Em 1981, o rendimento do trabalho principal correspondia a $82,7 \%$ do rendimento domiciliar total. Em 1990 a participação dessa parcela na renda total passa a ser 81,7\%, chegando, em 2001, a uma participação de 74,7\% no rendimento domiciliar total. No período analisado, em média, a sua participação no total foi de 79,9\%.

As aposentadorias e pensões contribuem com a segunda maior parcela no total dos rendimentos. Esse componente, ao longo do período analisado, aumentou a sua participação no valor do rendimento domiciliar per capita, principalmente a partir de 1989. Observa-se pela Tabela 17 e Figura 11 que, entre os anos de 1981 e 1990, as aposentadorias e pensões contribuíram com aproximadamente 9,7\% do total de rendimentos, enquanto nos anos de 1992 a 2001 a sua participação aumentou para $15,5 \%$. 
Tabela 17. Decomposição do valor médio (VM), em Reais ${ }^{1}$ de setembro de 2001, e a participação percentual $\left[(\%) \phi_{\mathrm{k}}\right]$ dos componentes do rendimento domiciliar per capita. Brasil, de 1981 a 2001

\begin{tabular}{|c|c|c|c|c|c|c|c|c|c|c|c|c|c|c|}
\hline \multirow{3}{*}{ ANO } & \multicolumn{14}{|c|}{ Valor médio e sua participação percentual } \\
\hline & \multicolumn{2}{|c|}{$\begin{array}{l}\text { Trabalho } \\
\text { principal }\end{array}$} & \multicolumn{2}{|c|}{$\begin{array}{l}\text { Outros } \\
\text { trabalhos }\end{array}$} & \multicolumn{2}{|c|}{$\begin{array}{l}\text { Aposent. e } \\
\text { pensões }\end{array}$} & \multicolumn{2}{|c|}{ Aluguéis } & \multicolumn{2}{|c|}{ Doações } & \multicolumn{2}{|c|}{ Juros, etc } & \multicolumn{2}{|c|}{ Total } \\
\hline & VM & $(\%) \phi_{\mathrm{k}}$ & VM & $(\%) \phi_{\mathrm{k}}$ & $\mathrm{VM}$ & $(\%) \phi_{\mathrm{k}}$ & VM & $(\%) \phi_{\mathrm{k}}$ & VM & $(\%) \phi_{\mathrm{k}}$ & VM & $(\%) \phi_{\mathrm{k}}$ & VM & $(\%) \phi_{\mathrm{k}}$ \\
\hline 1981 & 170,67 & 82,7 & 5,41 & 2,6 & 19,69 & 9,5 & 5,95 & 2,9 & - & - & 4,66 & 2,3 & 206,38 & 100,0 \\
\hline 1983 & 149,12 & 81,5 & 5,88 & 3,2 & 18,78 & 10,3 & 4,68 & 2,6 & - & - & 4,53 & 2,4 & 182,99 & 100,0 \\
\hline 1984 & 148,61 & 81,5 & 5,77 & 3,2 & 18,74 & 10,3 & 4,18 & 2,3 & - & - & 5,05 & 2,7 & 182,35 & 100,0 \\
\hline 1985 & 179,88 & 82,2 & 6,91 & 3,2 & 22,23 & 10,2 & 4,06 & 1,8 & - & - & 5,63 & 2,6 & 218,70 & 100,0 \\
\hline 1986 & 256,52 & 83,7 & 10,08 & 3,3 & 26,99 & 8,8 & 6,85 & 2,2 & - & - & 6,03 & 2,0 & 306,47 & 100,0 \\
\hline 1988 & 191,02 & 84,3 & 7,23 & 3,2 & 18,39 & 8,1 & 4,58 & 2,0 & - & - & 5,42 & 2,4 & 226,64 & 100,0 \\
\hline 1989 & 233,25 & 82,4 & 9,88 & 3,5 & 27,70 & 9,8 & 6,82 & 2,3 & - & - & 5,58 & 2,0 & 283,23 & 100,0 \\
\hline 1990 & 190,58 & 81,7 & 8,44 & 3,6 & 24,94 & 10,7 & 5,53 & 2,4 & - & - & 3,76 & 1,6 & 233,25 & 100,0 \\
\hline 1992 & 167,47 & 79,0 & 6,18 & 2,9 & 29,94 & 14,2 & 2,83 & 1,3 & 0,86 & 0,4 & 4,66 & 2,2 & 211,94 & 100,0 \\
\hline 1993 & 180,03 & 78,3 & 7,59 & 3,3 & 32,46 & 14,1 & 2,62 & 1,1 & 1,02 & 0,4 & 6,34 & 2,8 & 230,05 & 100,0 \\
\hline 1995 & 238,03 & 78,5 & 10,68 & 3,5 & 43,18 & 14,2 & 6,83 & 2,3 & 1,75 & 0,6 & 2,67 & 0,9 & 303,12 & 100,0 \\
\hline 1996 & 240,15 & 78,3 & 10,54 & 3,4 & 44,61 & 14,5 & 7,26 & 2,4 & 1,56 & 0,5 & 2,73 & 0,9 & 306,84 & 100,0 \\
\hline 1997 & 239,33 & 78,2 & 9,97 & 3,3 & 46,67 & 15,2 & 6,60 & 2,2 & 1,75 & 0,6 & 1,87 & 0,5 & 306,19 & 100,0 \\
\hline 1998 & 235,45 & 76,2 & 9,83 & 3,2 & 51,67 & 16,7 & 7,42 & 2,4 & 2,13 & 0,7 & 2,68 & 0,8 & 309,19 & 100,0 \\
\hline 1999 & 192,44 & 75,5 & 7,58 & 3,0 & 45,43 & 17,8 & 5,55 & 2,2 & 1,78 & 0,7 & 2,10 & 0,8 & 254,91 & 100,0 \\
\hline 2001 & 222,31 & 74,7 & 9,57 & 3,2 & 55,18 & 18,6 & 5,74 & 1,9 & 2,00 & 0,7 & 2,72 & 0,9 & 297,52 & 100,0 \\
\hline Média & 202,18 & 79,9 & 8,22 & 3,2 & 32,29 & 12,7 & 5,47 & 2,1 & 1,60 & 0,6 & 4,15 & 1,7 & 253,74 & 100,0 \\
\hline
\end{tabular}

Fonte: IBGE - dados individuais das PNADs de 1981 a 2001

${ }^{1}$ Utilizando como deflator o INPC-IBGE

Em 1981, o rendimento de aposentadorias e pensões correspondia a 9,5\% do rendimento domiciliar total. Em 1992, a participação dessa parcela na renda total passa a ser de 14,2\%. Em 2001, a sua participação na renda total chegou a 18,6\%. A partir de 
1992, observa-se que o crescimento da participação do valor das aposentadorias e pensões no rendimento domiciliar per capita tem sido cada vez mais acentuado, revelando a sua crescente importância para a renda domiciliar.

O componente juros, dividendos etc..., no período de 1981 a 1993, participou com aproximadamente $2,4 \%$ do valor do rendimento domiciliar per capita. A partir de 1995 , a sua participação caiu para menos de $1 \%$. Acredita-se que tal comportamento deve-se ao fim da correção monetária, com a implantação do Plano Real em 1994.

Os demais componentes do rendimento domiciliar per capita participaram no total dos rendimentos, em média, com 3,2\% para rendimento de outros trabalhos; $2,1 \%$ para rendimento de aluguéis e 0,6\% para rendimento de doações. Vale lembrar que os dados para o componente do rendimento domiciliar per capita "doações", estão disponíveis a partir da PNAD de 1992. 


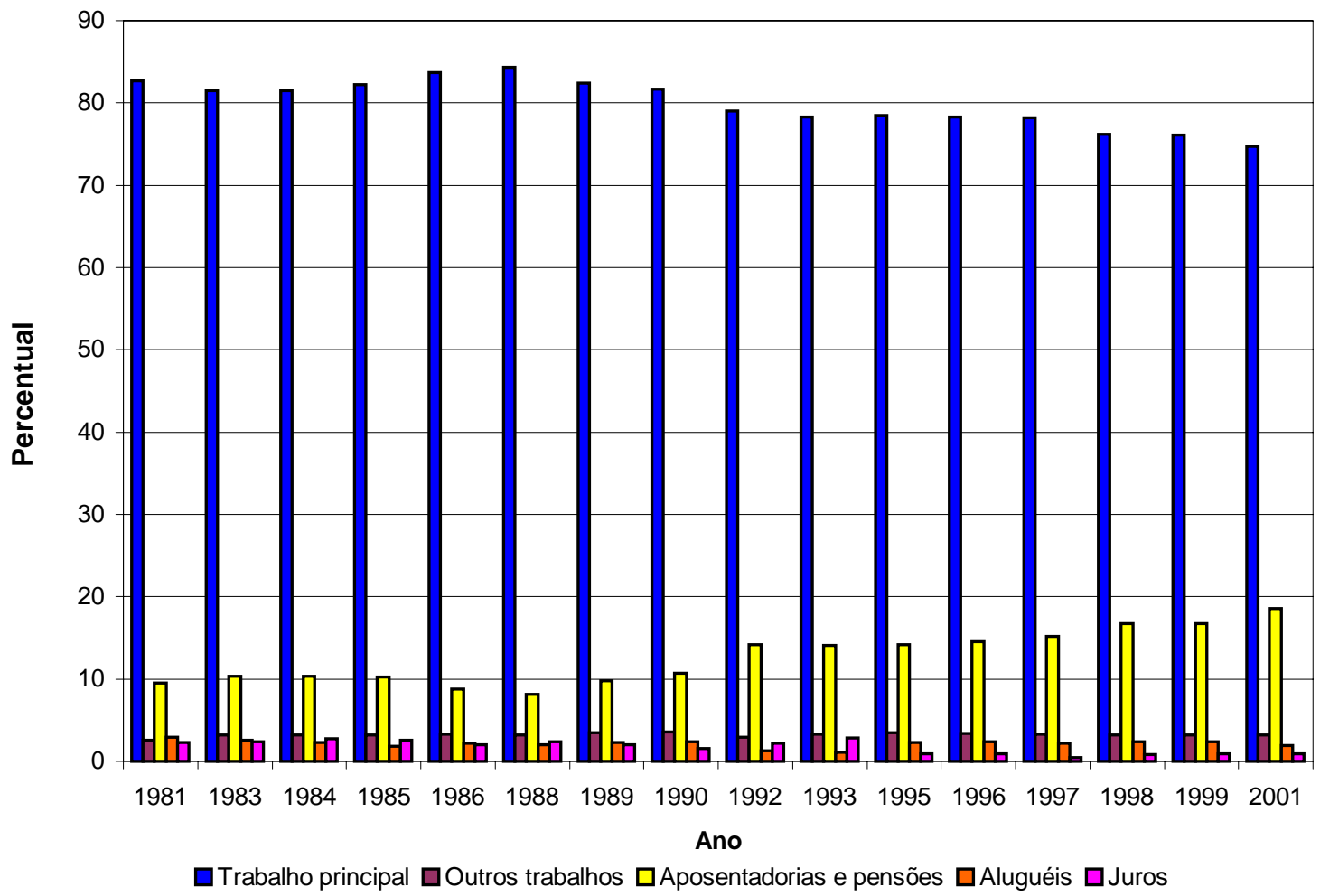

Figura 11 - Participação percentual dos componentes do rendimento domiciliar per capita. Brasil, 1981 a 2001

A Tabela 18 mostra os índices de Gini dos componentes do rendimento domiciliar per capita, a proporção das pessoas em domicílios com rendimento per capita igual a zero e a proporção de pessoas sem rendimentos. Observa-se que o índice de Gini para todos os componentes é elevado. Isso ocorre porque uma grande proporção das pessoas está em domicílios onde o componente é nulo.

O rendimento do trabalho principal per capita apresenta o menor índice de Gini, devido à pequena proporção de pessoas em domicílios sem esse tipo de rendimento. As aposentadorias e pensões vêm a seguir. Pode-se verificar também que a proporção de pessoas em domicílios onde esse componente é igual a zero tende a cair ao longo do período analisado, revelando que, ao longo dos anos, aumentou a proporção de pessoas em domicílios em que há pelo menos uma pessoa que recebe aposentadoria ou pensão. 
Tabela 18. Índice de Gini dos componentes do rendimento domiciliar per capita, proporção das pessoas em domicílios com rendimento per capita igual a zero e proporção de pessoas sem rendimentos. Brasil, de 1981 a 2001

\begin{tabular}{|c|c|c|c|c|c|c|c|c|c|c|c|c|c|c|c|c|}
\hline \multirow[t]{2}{*}{$\begin{array}{l}\text { Componente } \\
\text { do } \\
\text { rendimento }\end{array}$} & \multicolumn{16}{|c|}{$\begin{array}{l}\text { Indice de Gini dos componentes do rendimento } \\
\text { domiciliar per capita }-\left[\mathrm{G}\left(\mathrm{x}_{\mathrm{k}}\right)\right]\end{array}$} \\
\hline & 1981 & 1983 & 1984 & 1985 & 1986 & 1988 & 1989 & 1990 & 1992 & 1993 & 1995 & 1996 & 1997 & 1998 & 1999 & 2001 \\
\hline $\mathrm{TP}^{1}$ & 0,595 & 0,609 & 0,604 & 0,611 & 0,599 & 0,631 & 0,646 & 0,624 & 0,606 & 0,630 & 0,626 & 0,623 & 0,631 & 0,632 & 0,628 & 0,632 \\
\hline $\mathrm{OT}^{2}$ & 0,982 & 0,978 & 0,981 & 0,982 & 0,982 & 0,979 & 0,980 & 0,978 & 0,979 & 0,980 & 0,977 & 0,980 & 0,979 & 0,979 & 0,978 & 0,980 \\
\hline $\mathrm{AP}^{3}$ & 0,913 & 0,920 & 0,916 & 0,919 & 0,917 & 0,923 & 0,921 & 0,923 & 0,889 & 0,890 & 0,889 & 0,884 & 0,881 & 0,877 & 0,876 & 0,872 \\
\hline $\mathrm{A}^{4}$ & 0,975 & 0,980 & 0,982 & 0,984 & 0,986 & 0,983 & 0,992 & 0,986 & 0,990 & 0,989 & 0,986 & 0,985 & 0,986 & 0,985 & 0,986 & 0,986 \\
\hline $\mathrm{D}^{5}$ & - & - & - & - & - & - & - & - & 0,994 & 0,994 & 0,992 & 0,994 & 0,991 & 0,991 & 0,990 & 0,990 \\
\hline $\mathbf{J}^{6}$ & 0,984 & 0,970 & 0,922 & 0,918 & 0,931 & 0,935 & 0,960 & 0,970 & 0,989 & 0,987 & 0,991 & 0,993 & 0,994 & 0,992 & 0,991 & 0,983 \\
\hline $\begin{array}{c}\text { Componente } \\
\text { do } \\
\text { rendimento }\end{array}$ & \multicolumn{16}{|c|}{$\begin{array}{l}\text { Proporção de pessoas em domicílios com rendimento per capita igual a zero } \\
\text { Para os componentes do rendimento domiciliar per capita - }(\%)\end{array}$} \\
\hline $\mathrm{TP}^{1}$ & 5,4 & 6,1 & 5,5 & 5,2 & 4,8 & 4,8 & 5,3 & 5,8 & 7,0 & 7,3 & 7,4 & 8,6 & 8,5 & 9,4 & 9,3 & 10,0 \\
\hline $\mathrm{OT}^{2}$ & 94,2 & 91,9 & 93,4 & 93,4 & 93,7 & 92,5 & 92,8 & 92,7 & 93,3 & 92,2 & 92,2 & 93,4 & 92,9 & 92,6 & 92,9 & 93,4 \\
\hline $\mathrm{AP}^{3}$ & 76,4 & 77,1 & 76,4 & 76,2 & 75,3 & 77,0 & 74,6 & 74,0 & 72,8 & 72,1 & 70,3 & 69,0 & 68,6 & 67,9 & 67,7 & 67,8 \\
\hline$A^{4}$ & 93,0 & 94,3 & 94,4 & 94,8 & 95,0 & 94,5 & 95,2 & 95,4 & 96,6 & 96,7 & 96,1 & 95,9 & 96,2 & 95,9 & 96,2 & 96,3 \\
\hline $\mathrm{D}^{5}$ & - & - & - & - & - & - & - & - & 98,3 & 98,2 & 97,8 & 98,1 & 97,4 & 97,1 & 97,0 & 97,1 \\
\hline $\mathrm{J}^{6}$ & 91,4 & 85,2 & 65,1 & 63,1 & 68,9 & 61,3 & 64,9 & 69,8 & 89,6 & 88,4 & 94,5 & 95,7 & 96,3 & 95,6 & 95,9 & 91,4 \\
\hline
\end{tabular}

Proporção de pessoas sem rendimentos - $(\%)$

\begin{tabular}{rrrrrrrrrrrrrrrr}
\hline 0,6 & 0,9 & 0,5 & 0,4 & 0,4 & 0,5 & 0,5 & 0,8 & 1,2 & 1,0 & 1,3 & 1,7 & 1,4 & 1,3 & 1,2 & 1,6 \\
\hline
\end{tabular}

Fonte: IBGE - dados individuais das PNADS de 1981 a 2001

1 Trabalho Principal

${ }^{2}$ Outros trabalhos

${ }^{3}$ Aposentadorias e pensões

${ }_{5}^{4}$ Aluguéis

${ }^{5}$ Doações

${ }^{6}$ Juros, etc

O número de pessoas que está em domicílios sem nenhum rendimento elevou-se de 1981 para 1983, manteve-se razoavelmente constante entre 1984 e 1989, elevando-se, acentuadamente, a partir de 1989 até 1996, decrescendo entre 1997 e 1999, voltando a crescer em 2001, conforme pode ser visto na Figura 12. Observa-se que, na década de 90, a proporção de pessoas que está em domicílios sem rendimentos mais que dobrou, em comparação com a média da década de 80. Uma possível explicação para esse crescimento pode ter sido a mudança de questionário da PNAD, a partir de 1992. 


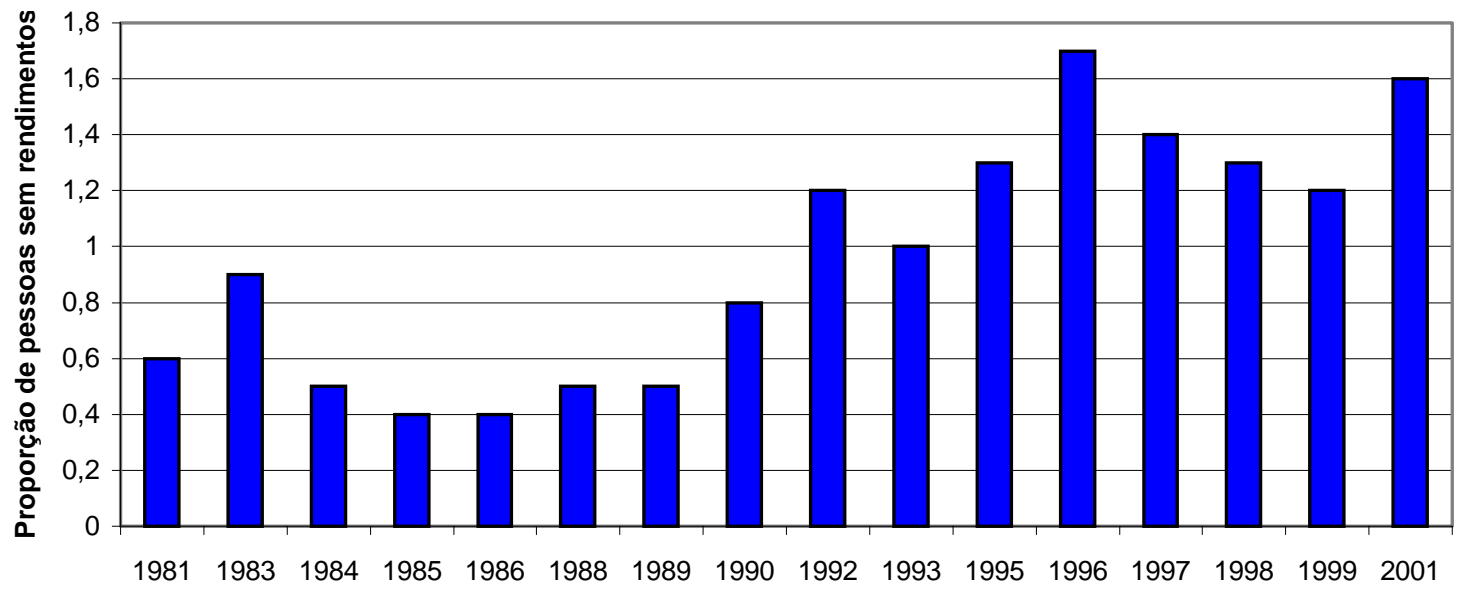

Ano

Figura 12 - Proporção de pessoas sem rendimentos. Brasil, 1981 a 2001

A Tabela 19 mostra a razão de concentração dos componentes do rendimento domiciliar per capita, $C\left(x_{k} \mid y\right)$, denotado na tabela como C. Sabe-se que um componente da renda contribui para aumentar a desigualdade quando a razão de concentração for maior que o índice de Gini. Os componentes do rendimento "outros trabalhos" e "aluguéis e juros" (com exceção dos anos de 1985 e 1986) tiveram razão de concentração maior do que o índice de Gini global e contribuíram para aumentar a desigualdade medida pelo índice de Gini. Os componentes "trabalho principal" e "doações" tiveram razão de concentração menor do que o índice de Gini global, ou seja, em todo o período analisado, esses dois componentes contribuíram para reduzir a desigualdade medida pelo índice de Gini.

Para aposentadorias e pensões, a razão de concentração cresceu na primeira metade dos anos 80, recuou em 1986, voltando a crescer a partir de 1988. Nos anos 90, a razão de concentração cresceu entre 1992 e 1995, recuando um pouco em 1996 e voltando a crescer, acentuadamente, no final dos anos 90, conforme a Figura 13. 
Tabela 19 . Razão de Concentração (C) na decomposição do índice de Gini do rendimento domiciliar per capita. Brasil, de 1981 a 2001

\begin{tabular}{|c|c|c|c|c|c|c|c|c|c|c|c|c|c|c|c|c|}
\hline \multirow{2}{*}{$\begin{array}{l}\text { Componente } \\
\text { do } \\
\text { rendimento }\end{array}$} & \multicolumn{16}{|c|}{ Razão de concentração (C) } \\
\hline & 1981 & 1983 & 1984 & 1985 & 1986 & 1988 & 1989 & 1990 & 1992 & 1993 & 1995 & 1996 & 1997 & 1998 & 1999 & 2001 \\
\hline $\mathrm{TP}^{1}$ & 0,566 & 0,577 & 0,572 & 0,582 & 0,574 & 0,608 & 0,620 & 0,595 & 0,565 & 0,589 & 0,587 & 0,588 & 0,591 & 0,585 & 0,579 & 0,581 \\
\hline $\mathrm{OT}^{2}$ & 0,768 & 0,759 & 0,797 & 0,804 & 0,808 & 0,787 & 0,808 & 0,796 & 0,758 & 0,765 & 0,766 & 0,784 & 0,767 & 0,748 & 0,745 & 0,785 \\
\hline $\mathrm{AP}^{3}$ & 0,569 & 0,609 & 0,588 & 0,597 & 0,564 & 0,573 & 0,615 & 0,632 & 0,576 & 0,579 & 0,586 & 0,580 & 0,585 & 0,599 & 0,603 & 0,603 \\
\hline$A^{4}$ & 0,778 & 0,797 & 0,812 & 0,812 & 0,833 & 0,801 & 0,882 & 0,820 & 0,802 & 0,784 & 0,813 & 0,802 & 0,796 & 0,803 & 0,803 & 0,797 \\
\hline$D^{5}$ & - & - & - & - & - & - & - & - & 0,368 & 0,423 & 0,399 & 0,436 & 0,380 & 0,413 & 0,354 & 0,395 \\
\hline $\mathbf{J}^{6}$ & 0,757 & 0,639 & 0,592 & 0,593 & 0,571 & 0,643 & 0,673 & 0,629 & 0,839 & 0,858 & 0,789 & 0,815 & 0,769 & 0,764 & 0,695 & 0,539 \\
\hline $\begin{array}{l}\text { Gini } \\
\text { total }\end{array}$ & 0,582 & 0,594 & 0,587 & $\mathbf{0 , 5 9 5}$ & 0,586 & 0,616 & $\mathbf{0 , 6 3 4}$ & 0,612 & $\mathbf{0 , 5 8 0}$ & $\mathbf{0 , 6 0 2}$ & $\mathbf{0 , 5 9 9}$ & $\mathbf{0 , 6 0 0}$ & $\mathbf{0 , 6 0 0}$ & $\mathbf{0 , 5 9 8}$ & $\mathbf{0 , 5 9 2}$ & $\mathbf{0 , 5 9 4}$ \\
\hline $\begin{array}{l}\text { Fonte: } \\
{ }^{1} \text { Traba } \\
{ }^{2} \text { Outro } \\
{ }^{3} \text { Apos } \\
{ }^{4} \text { Alug } \\
{ }^{5} \text { Doaç } \\
{ }_{6}^{6} \text { Juros }\end{array}$ & $\begin{array}{l}\text { lho P } \\
\text { s trab } \\
\text { entad } \\
\text { léis } \\
\text { ões } \\
\text { etc }\end{array}$ & $\begin{array}{l}\text { rinci } \\
\text { alho } \\
\text { orias }\end{array}$ & pal & Isões & & & & & & 200 & & & & & & \\
\hline
\end{tabular}

As aposentadorias e pensões apresentaram razão de concentração menor que o índice de Gini global em 9 dos 16 anos analisados. Para os anos de 1983, 1984, 1985, 1990, 1998, 1999 e 2001, a razão de concentração foi maior que o índice de Gini. Observa-se que, no final da década de 1990 e início do Século XXI, as aposentadorias e pensões deram uma contribuição maior para a desigualdade da distribuição do rendimento domiciliar per capita.

Esses resultados servem de alerta para os administradores da Previdência Social brasileira. Cechin (2002, p.9) afirma que "no Brasil, caso não houvesse uma reforma no sistema previdenciário, estaria perpetuando-se uma perversa redistribuição de renda, via Previdência Social, em que os mais pobres financiavam os mais ricos". Certamente a reforma previdenciária de 1998 acabou com algumas distorções, como a aposentadoria por tempo de serviço, mas não foi a reforma ideal, visto que o déficit previdenciário e a concentração de rendimentos de aposentadorias e pensões continuam. 


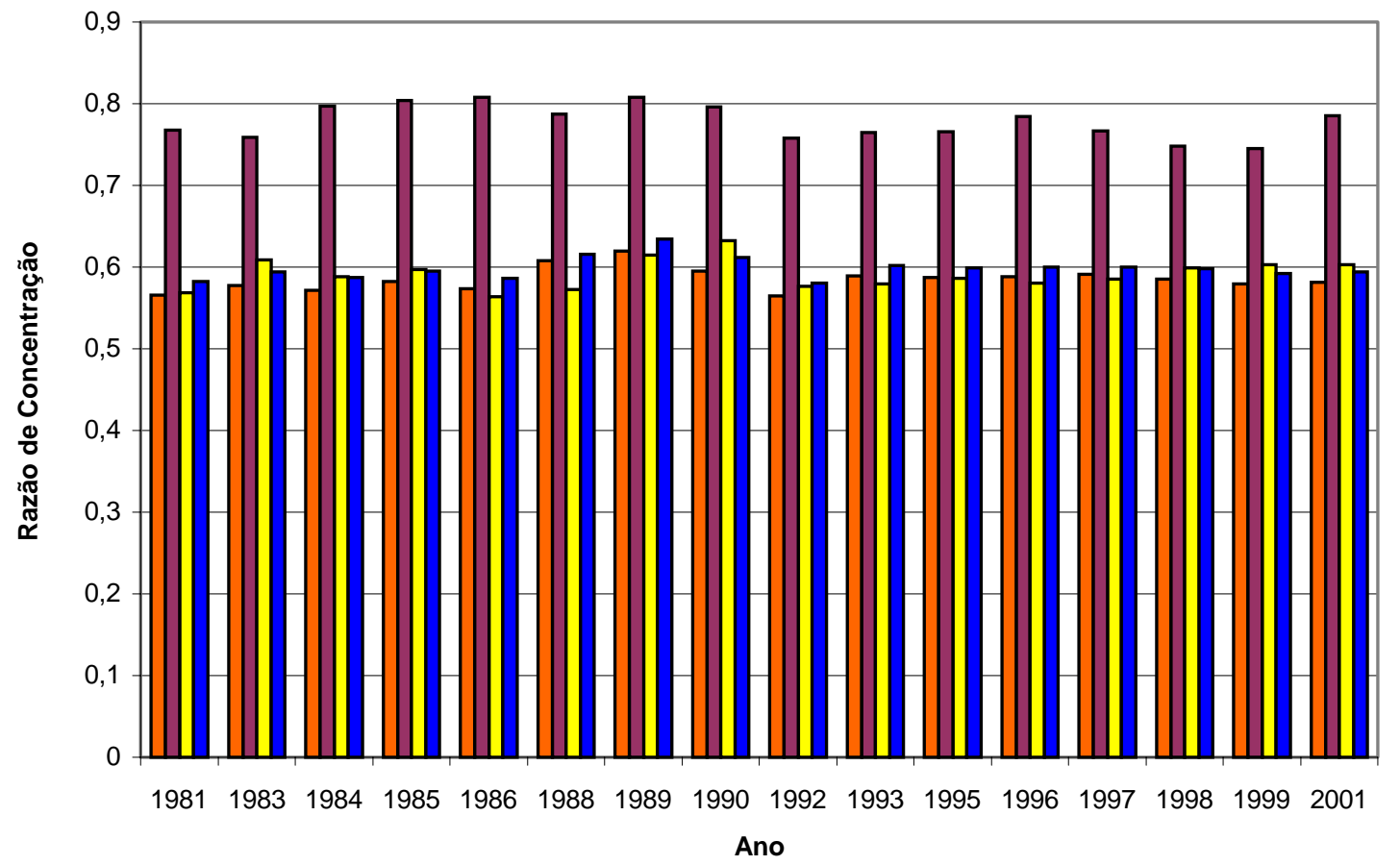

$\square$ Trabalho principal $\square$ Outros trabalhos $\square$ Aposentadorias e pensões $\square$ Gini Total

Figura 13 - Razão de concentração na composição do índice de Gini do rendimento domiciliar per capita. Brasil, 1981 a 2001

Observa-se que, em todo o período analisado, a razão de concentração para aposentadorias e pensões não apresentou recuos significativos. Pelo contrário, a tendência foi de crescimento. A razão de concentração para todos os componentes do rendimento domiciliar per capita foi positiva, mostrando que o valor de todos esses componentes tende a crescer com o rendimento domiciliar per capita.

Note-se que a razão de concentração de aposentadorias e pensões, ao longo do período analisado, é superior ou está ligeiramente abaixo da razão de concentração do rendimento do trabalho principal. O período de 1998 a 2001 apresenta razão de concentração de aposentadorias e pensões superior ao índice de Gini e, nos últimos dois anos, substancialmente maior do que a razão de concentração do rendimento de trabalho principal. 
Conforme demonstrado na metodologia sobre a decomposição do índice de Gini, pode-se obter a curva de concentração para os componentes do rendimento domiciliar per capita, para cada ano analisado. A Figura 14 ilustra as curvas de concentração para os componentes do rendimento domiciliar per capita, em 2001.

A curva preta é a curva de Lorenz da distribuição do rendimento domiciliar per capita. Essa curva é uma média ponderada das curvas de concentração das parcelas do rendimento domiciliar. Se a curva de concentração de uma parcela do rendimento ficar sempre abaixo da curva de Lorenz, essa parcela está contribuindo para aumentar a desigualdade da distribuição do rendimento domiciliar per capita.

Dessa forma, pode-se notar que a curva de concentração para doações, representada pela curva 5, é sensivelmente diferente das outras curvas e apresenta a menor área de concentração entre os componentes do rendimento domiciliar per capita analisados. Portanto, essa parcela contribui para reduzir a desigualdade da distribuição do rendimento domiciliar per capita.

As curvas de concentração para o trabalho principal (curva 1) e aposentadorias e pensões (curva 3) apresentam áreas de concentração semelhantes, mas observa-se que essa última se afasta mais da linha de perfeita igualdade e contribui para aumentar a desigualdade da distribuição do rendimento domiciliar per capita. 
CURVAS DE CONCENTRACAO-BRASIL-2001

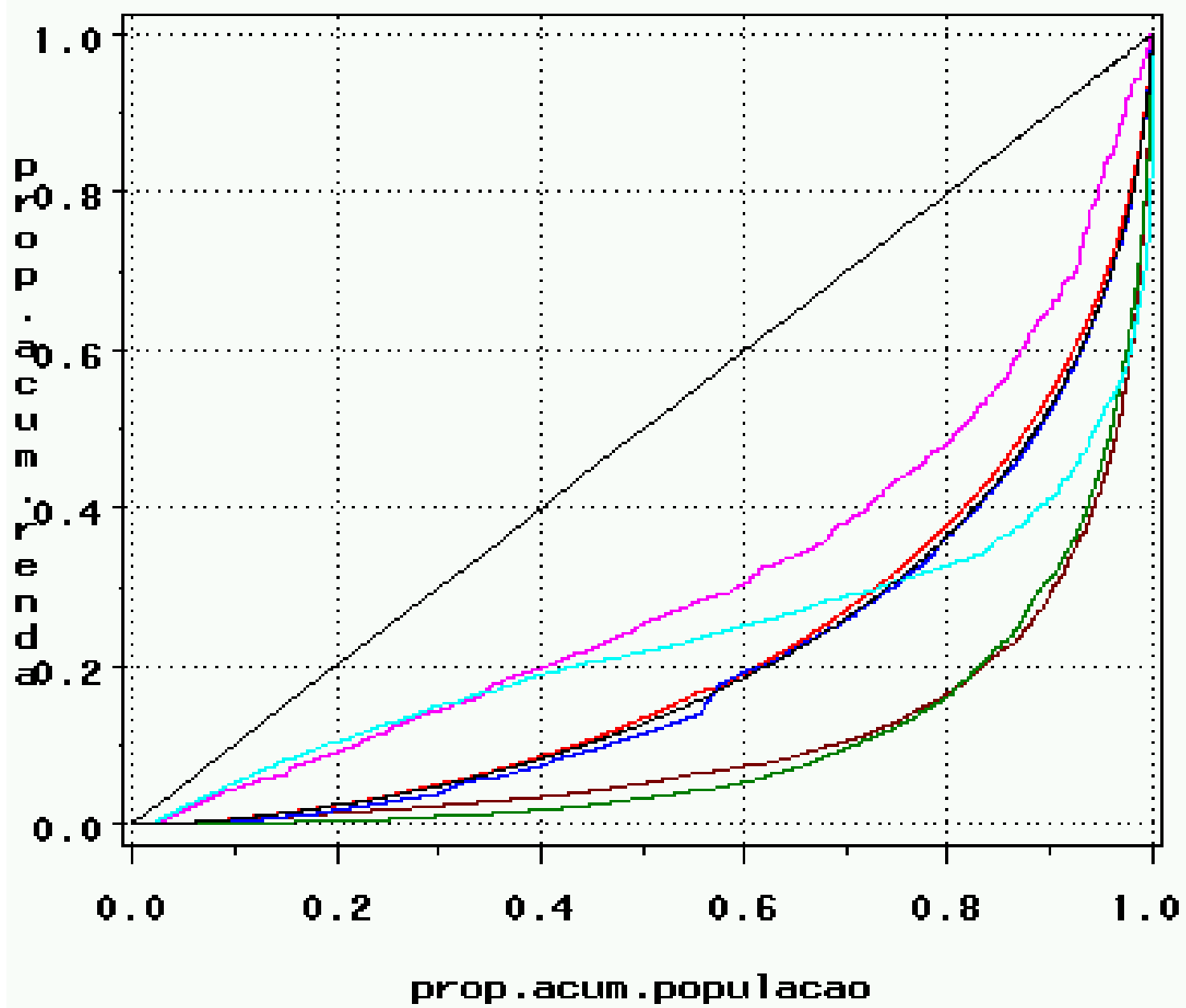

Figura 14 - Curvas de concentração para os componentes do rendimento domiciliar per capita. Brasil, 2001

${ }^{1}$ trabalho principal; ${ }^{2}$ outros trabalhos; ${ }^{3}$ aposentadorias e pensões; ${ }^{4}$ aluguel; ${ }^{5}$ doações e ${ }^{6}$ juros, etc.

Observa-se que a curva 3, ou curva de concentração de aposentadorias e pensões, apresenta alguns "degraus" ao longo da sua curvatura. O degrau mais acentuado está ao redor do 56 percentil da distribuição do rendimento domiciliar per capita. A

explicação para tal situação é que mais da metade da população beneficiária de 
aposentadoria e pensão recebe benefício no valor de 1 salário mínimo, conforme mencionado no trabalho de Barros et al. (1999) e Brant (2001a), e os percentis de ordem 56 e 57 da distribuição domiciliar per capita são iguais a 1 salário mínimo (R \$ 180,00 em setembro de 2001).

A curva de concentração para juros, dividendos etc (curva 6) indica que o percentual mais rico da população fica com a maior parte da renda de juros, dividendos etc.

As curvas de concentração para outros trabalhos (curva 2) e aluguel (curva 4) apresentam as duas maiores áreas de concentração e são, respectivamente, a quinta e a sexta maiores áreas de concentração para o ano de 2001. Essas duas parcelas estão contribuindo para aumentar a desigualdade da distribuição do rendimento domiciliar per capita.

A Tabela 20 mostra a participação de cada componente para a formação do índice de Gini e a sua participação, em termos percentuais, para a formação do índice de Gini global.

Observa-se que o rendimento do trabalho principal é, em todo o período, o componente com a maior participação na formação do índice de Gini do rendimento domiciliar per capita, seguido pelo rendimento de aposentadorias e pensões, conforme pode-se verificar na Figura 15.

Ao longo do período analisado, verifica-se que os rendimentos do trabalho principal, em média, representam 79,9\% do rendimento total (Tabela 17) e originam a maior parcela do índice de Gini, participando com 78,1\% (Tabela 20). 
Tabela 20 . Parcelas do índice de Gini $\left[\phi_{k} C\left(x_{k} \mid y\right)\right]$ e o respectivo percentual, na formação do índice de Gini Global dos componentes do rendimento domiciliar per capita. Brasil, 1981 a 2001

\begin{tabular}{|c|c|c|c|c|c|c|c|c|c|c|c|c|c|c|}
\hline \multirow{3}{*}{ ANO } & \multicolumn{14}{|c|}{ Parcelas do índice de Gini $\left[\phi_{\mathrm{h}} \mathrm{C}\left(\mathrm{x}_{\mathrm{k}} \mid \mathrm{y}\right)\right]$ e as suas respectivas percentagens $(\%)$} \\
\hline & \multicolumn{2}{|c|}{$\begin{array}{l}\text { Trabalho } \\
\text { principal }\end{array}$} & \multicolumn{2}{|c|}{$\begin{array}{l}\text { Outros } \\
\text { trabalhos }\end{array}$} & \multicolumn{2}{|c|}{$\begin{array}{l}\text { Aposent. e } \\
\text { pensões }\end{array}$} & \multicolumn{2}{|c|}{ Aluguéis } & \multicolumn{2}{|c|}{ Doações } & \multicolumn{2}{|c|}{ Juros,etc } & \multicolumn{2}{|c|}{ Total } \\
\hline & $\phi_{\mathrm{h}} \mathrm{C}\left(\mathrm{x}_{\mathrm{k}} \mid \mathrm{y}\right)$ & $\%$ & $\phi_{\mathrm{h}} \mathrm{C}\left(\mathrm{x}_{\mathrm{k}} \mid \mathrm{y}\right)$ & $\%$ & $\phi_{\mathrm{h}} \mathrm{C}\left(\mathrm{x}_{\mathrm{k}} \mid \mathrm{y}\right)$ & $\%$ & $\phi_{\mathrm{h}} \mathrm{C}\left(\mathrm{x}_{\mathrm{k}} \mid \mathrm{y}\right)$ & $\%$ & $\phi_{\mathrm{h}} \mathrm{C}\left(\mathrm{x}_{\mathrm{k}} \mid \mathrm{y}\right)$ & $\%$ & $\phi_{\mathrm{h}} \mathrm{C}\left(\mathrm{x}_{\mathrm{k}} \mid \mathrm{y}\right)$ & $\%$ & $\phi_{\mathrm{h}} \mathrm{C}\left(\mathrm{x}_{\mathrm{k}} \mid \mathrm{y}\right)$ & $\%$ \\
\hline 1981 & 0,468 & 80,4 & 0,020 & 3,5 & 0,054 & 9,3 & 0,023 & 3,9 & - & - & 0,017 & 2,9 & 0,582 & 100,0 \\
\hline 1983 & 0,471 & 79,3 & 0,024 & 4,1 & 0,063 & 10,5 & 0,020 & 3,4 & - & - & 0,016 & 2,7 & 0,594 & 100,0 \\
\hline 1984 & 0,467 & 79,4 & 0,025 & 4,3 & 0,060 & 10,3 & 0,019 & 3,2 & - & - & 0,016 & 2,8 & 0,587 & 100,0 \\
\hline 1985 & 0,479 & 80,5 & 0,025 & 4,2 & 0,061 & 10,3 & 0,015 & 2,5 & - & - & 0,015 & 2,5 & 0,595 & 100,0 \\
\hline 1986 & 0,480 & 81,9 & 0,026 & 4,5 & 0,050 & 8,5 & 0,019 & 3,2 & - & - & 0,011 & 1,9 & 0,586 & 100,0 \\
\hline 1988 & 0,512 & 83,3 & 0,025 & 4,1 & 0,047 & 7,6 & 0,016 & 2,6 & - & - & 0,015 & 2,4 & 0,616 & 100,0 \\
\hline 1989 & 0,511 & 80,6 & 0,028 & 4,4 & 0,060 & 9,5 & 0,021 & 3,3 & - & - & 0,014 & 2,2 & 0,634 & 100,0 \\
\hline 1990 & 0,486 & 79,4 & 0,029 & 4,7 & 0,068 & 11,0 & 0,019 & 3,2 & - & - & 0,010 & 1,2 & 0,612 & 100,0 \\
\hline 1992 & 0,446 & 76,9 & 0,022 & 3,8 & 0,081 & 14,0 & 0,011 & 1,9 & 0,002 & 0,3 & 0,018 & 3,1 & 0,580 & 100,0 \\
\hline 1993 & 0,461 & 76,5 & 0,025 & 4,2 & 0,082 & 13,6 & 0,009 & 1,5 & 0,002 & 0,3 & 0,023 & 3,9 & 0,602 & 100,0 \\
\hline 1995 & 0,461 & 77,0 & 0,027 & 4,5 & 0,084 & 14,0 & 0,018 & 3,0 & 0,002 & 0,4 & 0,007 & 1,1 & 0,599 & 100,0 \\
\hline 1996 & 0,461 & 76,8 & 0,027 & 4,5 & 0,084 & 14,0 & 0,019 & 3,2 & 0,002 & 0,3 & 0,007 & 1,2 & 0,600 & 100,0 \\
\hline 1997 & 0,462 & 77,0 & 0,025 & 4,2 & 0,089 & 14,8 & 0,017 & 2,8 & 0,002 & 0,4 & 0,005 & 0,8 & 0,600 & 100,0 \\
\hline 1998 & 0,446 & 74,5 & 0,024 & 4,0 & 0,100 & 16,7 & 0,019 & 3,2 & 0,003 & 0,5 & 0,006 & 1,1 & 0,598 & 100,0 \\
\hline 1999 & 0,437 & 73,7 & 0,022 & 3,7 & 0,107 & 18,2 & 0,018 & 3,0 & 0,002 & 0,4 & 0,006 & 1,0 & 0,592 & 100,0 \\
\hline 2001 & 0,434 & 73,0 & 0,025 & 4,3 & 0,112 & 18,8 & 0,015 & 2,6 & 0,003 & 0,4 & 0,005 & 0,8 & 0,594 & 100,0 \\
\hline Média & 0,468 & 78,1 & 0,025 & 4,2 & 0,075 & 12,6 & $\mathbf{0 , 0 1 7}$ & 2,9 & 0,002 & 0,4 & $\mathbf{0 , 0 1 2}$ & 2,0 & 0,598 & 100,0 \\
\hline
\end{tabular}

Fonte: IBGE - dados individuais das PNADs de 1981 a 2001.

Entre os demais componentes do rendimento, as aposentadorias e pensões vêm a seguir, representando, em média, $12,7 \%$ do rendimento total, originando a segunda maior parcela do índice de Gini, com 12,6\%. Em 1981, a contribuição dessa parcela para o índice de Gini foi de 9,3\%. Essa participação foi razoavelmente estável no período de 
1981 a 1985 , diminuiu de 1986 a 1988 e voltou a crescer a partir de 1989, quando contribuiu com 9,5\%. Em 1992, a contribuição dessa parcela para o índice de Gini total passa a ser de $14 \%$, acentuando esse crescimento na segunda metade dos anos 90, principalmente nos anos de 1998 e 1999. A sua participação cresce ainda mais em 2001, quando atinge 18,8\% do índice de Gini, sendo esse o maior percentual de todo o período de 1981 a 2001.

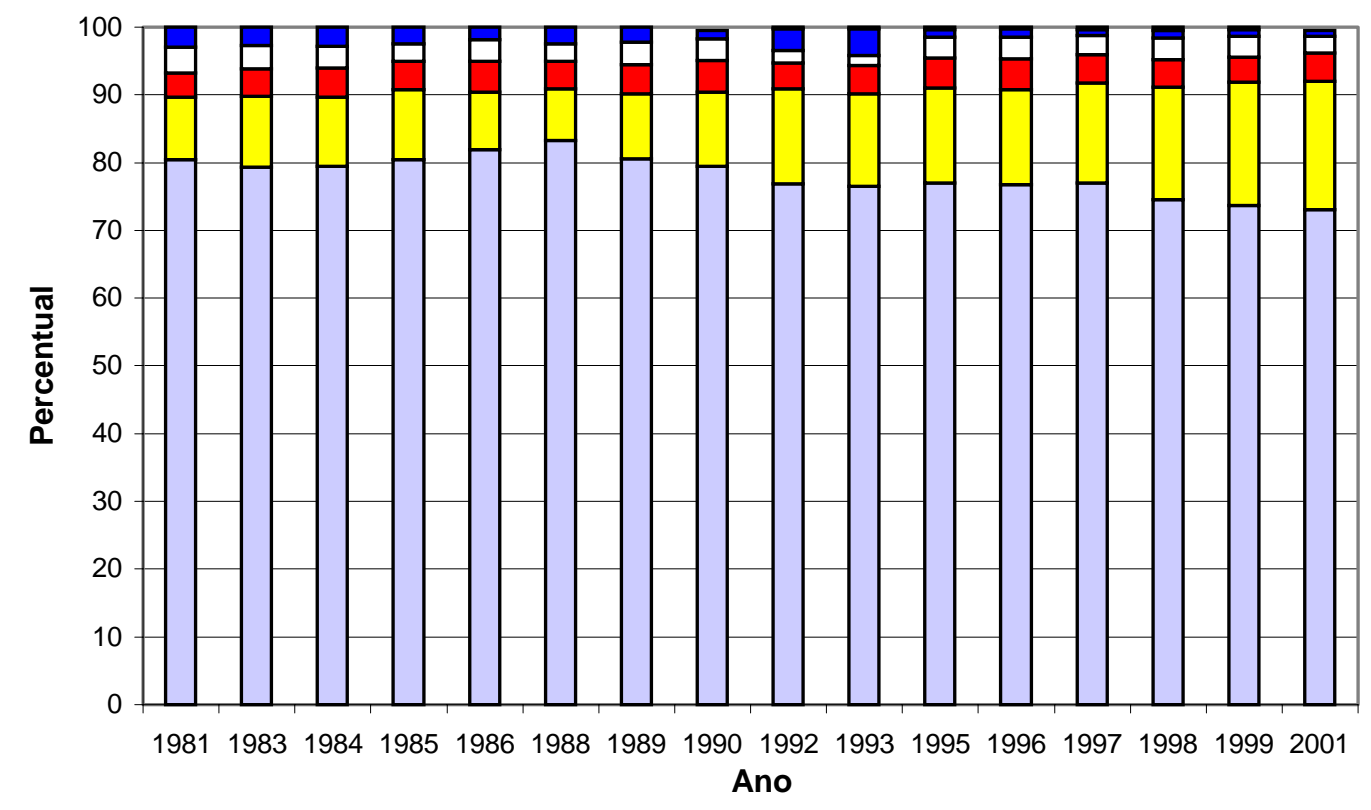

$\square$ Trabalho principal $\square$ Aposentadorias e pensões $\square$ Outros trabalhos $\square$ Aluguéis $\square$ Juros, etc $\square$ Doações

Figura 15 - Percentagens das parcelas do índice de Gini. Brasil, 1981 a 2001

Entre 1992 e 2001, a parcela do índice de Gini do rendimento domiciliar per capita referente ao rendimento do trabalho principal diminui 0,012 , ao mesmo tempo que a parcela referente ao rendimento de aposentadorias e pensões aumenta 0,031.

Portanto, as aposentadorias e pensões contribuem significativamente na formação do índice de Gini em todo o período analisado, com clara tendência de crescimento na década de 90 . 
Esses resultados corroboram os trabalhos de Hoffmann (2002a e 2002b), mostrando a importância dos rendimentos das aposentadorias e pensões na formação do índice de Gini.

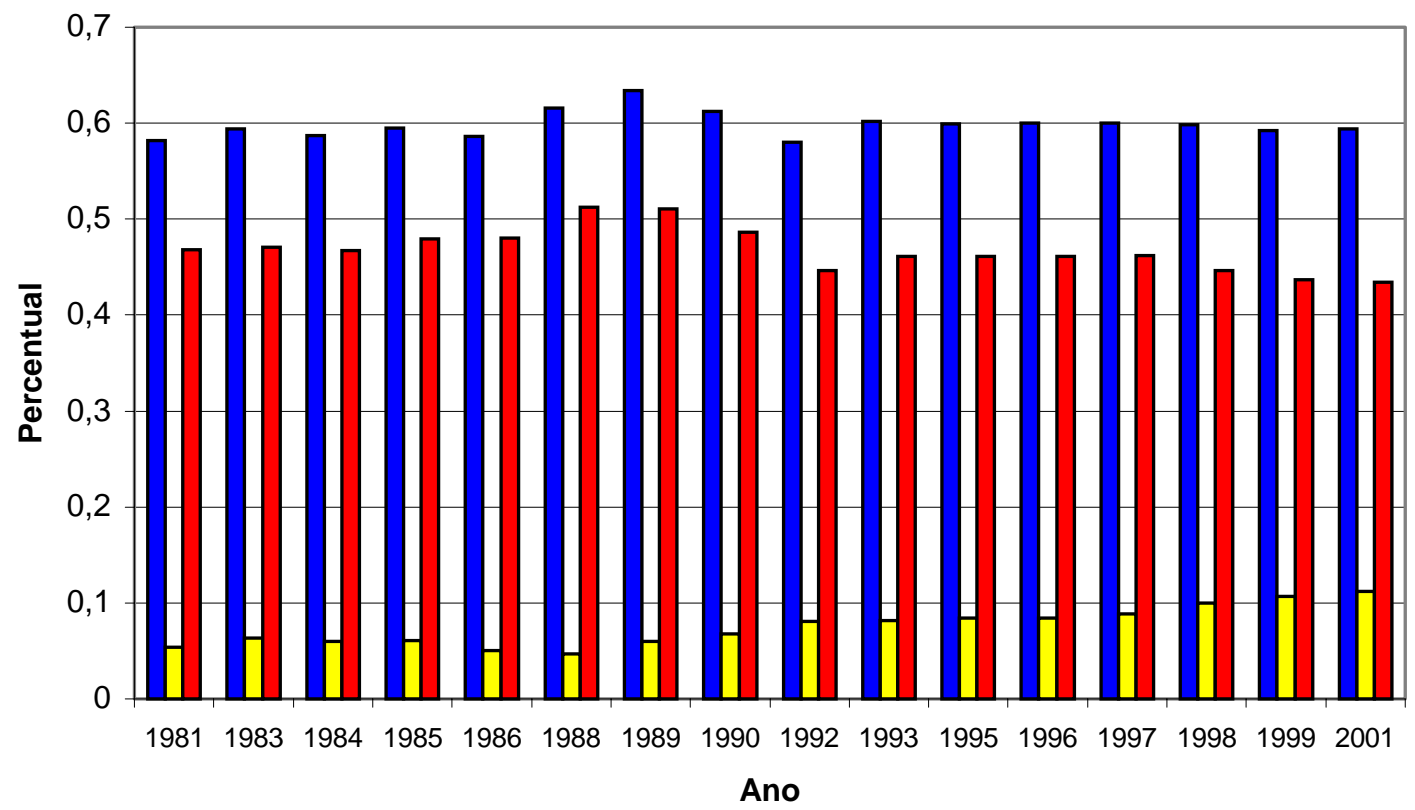

$\square$ Gini total $\square$ Aposentadorias e pensões $\square$ Trabalho principal

Figura 16 - Índice de Gini global, parcela do índice de Gini para aposentadorias e pensões e para o trabalho principal. Brasil, 1981 a 2001

O índice de Gini total manteve-se alto durante todo o período analisado, comprovando que o rendimento domiciliar per capita é mal distribuído. O maior valor desse índice foi em 1989, atingindo 0,634. Nos anos seguintes, o seu valor diminuiu, contrastando com o aumento da participação das aposentadorias e pensões na formação desse índice, conforme pode ser visto na Figura 16.

Para que se possa explicar a crescente contribuição das aposentadorias e pensões na desigualdade da distribuição do rendimento domiciliar per capita, a comparação com a parcela do rendimento de todos os trabalhos é bastante apropriada. A Tabela 21 e a 
Figura 17 mostram a evolução da desigualdade da distribuição da renda entre pessoas economicamente ativas (PEA) com algum rendimento e da distribuição do rendimento domiciliar per capita para o Brasil de 1981 a 2001.

A evolução da desigualdade da distribuição da renda entre pessoas economicamente ativas, medida através do índice de Gini, mostra valores relativamente baixos em 1981 e 1992, um grande crescimento em 1988 e 1989, um valor elevado em 1993, redução em 1995 e 1996, estabilidade entre 1996 e 1997, voltando a decrescer em 1998 e 1999.

Observa-se que, entre 1993 e 2001, o índice de Gini apresentou tendência de redução da desigualdade entre pessoas economicamente ativas com rendimento. Nesse período, o índice de Gini da PEA para o Brasil diminuiu 0,033. De acordo com Hoffmann (2002a), quando são consideradas todas as pessoas economicamente ativas com declaração de rendimento de todas as fontes, a redução da desigualdade é menor, mas não é desprezível. 
Tabela 21. Índice de Gini para a distribuição do rendimento das pessoas economicamente ativas $\left(\mathrm{G}_{\mathrm{PEA}}\right)$ e para a distribuição do rendimento domiciliar per capita $\left(\mathrm{G}_{\mathrm{RDPC}}\right)$. Brasil, de 1981 a 1999

\begin{tabular}{lll}
\hline ANO & $\mathrm{G}_{\mathrm{PEA}}{ }^{(1)}$ & $\mathrm{G}_{\mathrm{RDPC}}$ \\
\hline 1981 & 0,572 & 0,582 \\
1983 & 0,591 & 0,594 \\
1984 & 0,586 & 0,587 \\
1985 & 0,599 & 0,595 \\
1986 & 0,589 & 0,586 \\
1988 & 0,617 & 0,616 \\
1989 & 0,636 & 0,634 \\
1990 & 0,607 & 0,612 \\
1992 & 0,574 & 0,580 \\
1993 & 0,604 & 0,602 \\
1995 & 0,589 & 0,599 \\
1996 & 0,585 & 0,600 \\
1997 & 0,585 & 0,600 \\
1998 & 0,581 & 0,598 \\
1999 & 0,572 & 0,592 \\
2001 & 0,571 & 0,594 \\
\hline
\end{tabular}

Fonte: $\mathrm{G}_{\mathrm{PEA}}-$ Hoffmann (2002b)

$\mathrm{G}_{\mathrm{RDPC}}$ - IBGE - PNADs de 1981 a 1999

(1) Estimativas obtidas a partir de tabela de distribuição de freqüência em 8 estratos.

A Figura 17 mostra a evolução da medida de desigualdade da distribuição do rendimento domiciliar per capit ${ }^{16}$. Nesse período, o índice de Gini do rendimento domiciliar per capita para o Brasil diminuiu 0,008. Constata-se que houve diminuição

\footnotetext{
16 A distribuição do rendimento das pessoas economicamente ativas é apropriada para analisar as mudanças mais diretamente associadas ao mercado de trabalho. Para analisar as diferenças de nível de renda, é mais apropriado considerar a classificação das pessoas de acordo com o rendimento domiciliar per capita.
} 
da desigualdade, mas essa diminuição é bem menos intensa do que no caso da distribuição do rendimento das pessoas economicamente ativas com rendimento, principalmente a partir de 1995.

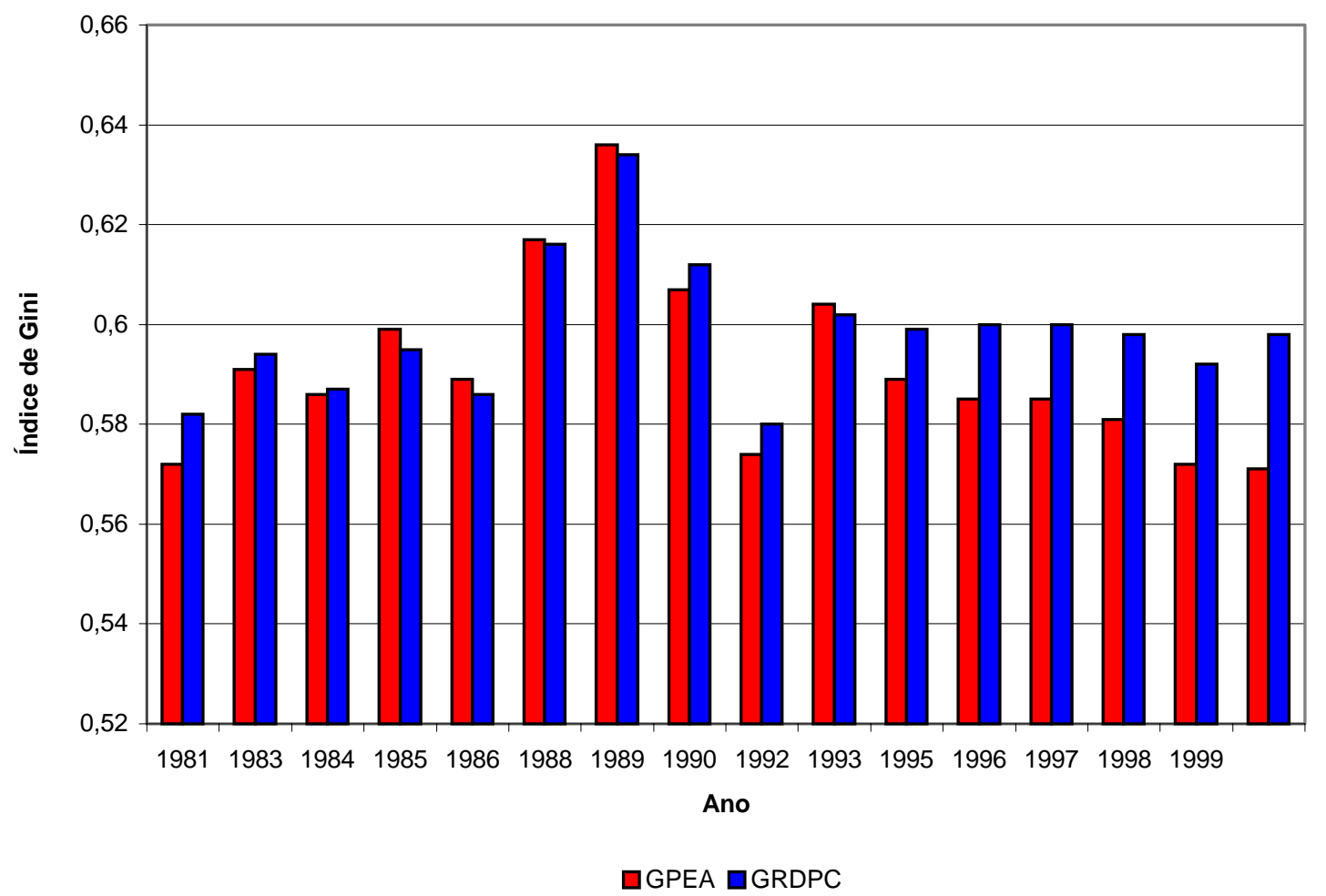

Figura 17 - Evolução da desigualdade da distribuição da renda entre pessoas economicamente ativas com algum rendimento (PEA) e da distribuição do rendimento domiciliar per capita (RDPC) para o Brasil, de 1981 a 1999

Essa diferença de comportamento das duas distribuições pode ser explicado através da participação dos rendimentos de todos os trabalhos e da participação dos rendimentos das aposentadorias e pensões. A tabela 20, mostra que a participação dos rendimentos de todos os trabalhos, em 1993, foi de 0,486 e, em 2001, de 0,459, revelando que a participação desse componente diminuiu 0,027. Já a participação dos rendimentos das aposentadorias e pensões em 1993 foi de 0,082 e, em 2001, de 0,112, 
crescendo 0,030. O efeito compensatório nessas duas parcelas explica a relativa estabilidade do índice de Gini para o período.

A tendência de diminuição da participação dos rendimentos de todos os trabalhos no rendimento total pode ser consequiência da redução da participação dos salários no total da produção brasileira, conforme observação de Najberg \& Ikeda (1999). Além disso, o mercado de trabalho formal tem constantemente apresentado quedas. Essas tendências contribuem bastante para diminuir a arrecadação da Previdência Social.

O aumento da participação de renda das aposentadorias e pensões no rendimento total está associado ao crescente envelhecimento da população e essa tendência é de crescimento, porque a população brasileira tem apresentado baixas taxas de fecundidade, aumento de longevidade e urbanização acelerada, levando a um maior crescimento da população idosa em relação aos demais grupos etários.

A combinação de mudanças na composição do mercado de trabalho, crescente informalização, flexibilização das relações trabalhistas, crescimento da população idosa, somados aos problemas existentes nos critérios e requisitos do sistema previdenciário, torna inviável o sistema vigente, devido ao constante crescimento do déficit previdenciário. 


\section{CONCLUSÃO}

Os problemas da previdência social no Brasil, como se viu, são de longa data e, no decorrer dos anos, não houve a preocupação em solucioná-los, postergando ao máximo os ajustes necessários.

Alguns fatores, como a Constituição de 1988, mudanças no mercado de trabalho, envelhecimento da população, fim das altas taxas inflacionárias, critérios e requisitos dos regimes de previdência social, têm contribuído negativamente para o bom andamento do sistema previdenciário.

As alterações recentes na demografia brasileira são importantes e influenciam diretamente o sistema previdenciário. Observa-se que atualmente há um constante decréscimo na taxa de natalidade e aumento da expectativa média de vida. A consequiência disso é o envelhecimento da população. O rápido crescimento do número de idosos na população e o aumento dos inativos em relação à população economicamente ativa têm sido um crescente problema enfrentado pelo modelo de repartição simples, à medida que diminui a base de contribuintes.

Ao longo dos últimos anos, o percentual de trabalhadores com carteira assinada tem diminuído. Por exemplo, em 1999, cerca de 55\% dos trabalhadores brasileiros não contribuíram para a previdência social. Esses dados são reflexo do crescimento do mercado informal no país, atribuído à tecnologia, à reestruturação empresarial, à queda na contratação formal e ao aumento das cooperativas de trabalho. Dessa forma, existe a necessidade de revisão na estrutura tributária e na legislação trabalhista, de modo a 
aumentar os incentivos à regularização do mercado informal. A base de contribuintes da previdência no Brasil está muito aquém do potencial produtivo do país. A consequiência da queda da base de contribuição é a diminuição da relação contribuinte/beneficiário. Esse decréscimo na relação, no modelo de repartição simples, leva a aumento das alíquotas de contribuição ou à redução no valor real dos benefícios.

O estabelecimento de novas regras previdenciárias, na Constituição de 1988 contribuiu para que o sistema previdenciário brasileiro se tornasse cada vez mais deficitário e insustentável. A ampliação dos benefícios para os trabalhadores rurais, sem as fontes de financiamento adequadas ou contrapartida suficiente de receita, é um exemplo. Já a instituição do Regime Jurídico Único, incluindo, subitamente, milhares de empregados da União, estados e municípios, que contribuíam para o regime geral e que se aposentariam pelas regras do INSS, e passaram a se aposentar por conta do setor público, tornou-se um dos principais problemas dentro do sistema previdenciário, comprometendo inclusive a estabilidade fiscal do país. Embora essa questão não possa ser analisada pormenorizadamente com os dados da PNAD, sabe-se que o Regime dos Servidores Públicos encontra-se com diversas distorções, levando o sistema previdenciário a apresentar crescentes déficits e a contribuir para aumentar a desigualdade da distribuição da renda no Brasil.

No caso da distribuição da renda, através dos dados das PNADs de 1981 a 2001, conclui-se que o rendimento das aposentadorias e pensões tende a reproduzir a distribuição da renda no Brasil. O volume de recursos gastos com esses benefícios é elevado, mas distribuído de forma desigual, como foi comprovado através da análise da distribuição dos componentes do rendimento domiciliar per capita em estratos.

Tomando apenas o ano de 2001, verifica-se que, na distribuição do rendimento domiciliar per capita, 50,5\% dos domicílios recebem até um salário mínimo, ficam com $16,9 \%$ da renda total e $17,4 \%$ da renda das aposentadorias e pensões, enquanto $16,2 \%$ dos domicílios recebem mais de três salários mínimos e se apropriam de 52,2\% da renda 
total e 52,9\% das aposentadorias e pensões. Os resultados referentes ao rendimento total são coerentes com o fato de que, na distribuição do rendimento domiciliar per capita, em 2001, os $50 \%$ mais pobres ficam com $12,7 \%$ do rendimento e os $10 \%$ mais ricos ficam com $47,2 \%$ do total.

Esses dados mostram que o maior percentual de domicílios e de pessoas recebe até um salário mínimo, mas fica com o menor percentual do rendimento total e das aposentadorias e pensões. Em contraste, os estratos superiores, que abrigam os relativamente mais ricos, apresentam um percentual pequeno de domicílios e pessoas, mas ficam com o maior percentual do rendimento total e do rendimento de aposentadorias e pensões.

Dessa forma, verifica-se que o rendimento de aposentadorias e pensões no Brasil está concentrado nos estratos superiores da distribuição da renda, onde estão os relativamente mais ricos, contribuindo para elevar a desigualdade dessa distribuição.

Observa-se que a participação do estrato de rendimento agregado "até um salário mínimo", no rendimento de pensões, é superior ao de aposentadorias, quando analisado separadamente. A participação do estrato de rendimento agregado "maior que três salários mínimos", no rendimento das aposentadorias, é superior ao de pensões, o mesmo ocorrendo com a participação do estrato de "mais de oito salários mínimos". Nesses três estratos de rendimentos, o rendimento de aposentadorias e pensões ficou acima do rendimento de todos os trabalhos.

No período analisado a participação do componente aposentadorias e pensões no rendimento total é uma das mais elevadas em todos os estratos, ficando atrás apenas da participação do trabalho principal. Individualmente, a participação das aposentadorias é sempre superior à das pensões. Verifica-se, também, que, no período analisado, houve crescimento da participação do rendimento de aposentadorias e pensões no rendimento total e queda na do trabalho principal. 
Observa-se que as aposentadorias e pensões, entre todos os componentes do rendimento domiciliar per capita, apresentaram o segundo menor valor do índice de Gini, devido ao fato de que a proporção de pessoas em domicílios com alguma aposentadoria ou pensão é elevada. Ressalta-se, porém, que a proporção de pessoas que está em domicílios sem nenhum rendimento elevou-se.

A decomposição do índice de Gini mostra que o rendimento de aposentadorias e pensões participou com a segunda maior parcela desse índice em todo o período analisado. Destaca-se que houve um nítido aumento dessa participação na década de 90.

A razão de concentração das aposentadorias e pensões, particularmente a partir de 1998, é superior ao índice de Gini é superior à razão de concentração do rendimento do trabalho principal. Esses resultados mostram que os rendimentos de aposentadorias e pensões, administradas pelo governo federal, estão contribuindo para a aumentar a desigualdade da distribuição da renda no Brasil, mostrando mais uma vez a necessidade de reforma do sistema previdenciário. É importante notar que um componente dos rendimentos que está diretamente sujeito a normas e leis, como as aposentadorias e pensões, esteja contribuindo para aumentar a desigualdade.

Os valores do índice de Gini da população economicamente ativa e do rendimento domiciliar per capita mostram a elevada desigualdade da distribuição da renda no Brasil. Observa-se que entre 1993 e 2001 houve uma redução da desigualdade da distribuição do rendimento das pessoas economicamente ativas. A redução da desigualdade no período torna-se quase desprezível quando é analisada a distribuição do rendimento domiciliar per capita. Esse fenômeno pode ser explicado, basicamente, pela crescente participação de aposentadorias e pensões na determinação da desigualdade.

Assim, evidencia-se a existência de problemas no sistema previdenciário do Brasil quanto à concentração do rendimento de aposentadorias e pensões. Exemplos de benefícios concedidos, como as aposentadorias por tempo de serviço, sem limitação de 
idade ou altos valores de aposentadorias e pensões que são pagos a uma minoria, sem que tenham contribuído com um valor adequado para isso, certamente contribuem para aumentar a desigualdade. As regras em vigor têm permitido que alguns segmentos da sociedade sejam privilegiados em detrimento de uma grande maioria. Observa-se que está havendo uma redistribuição invertida de renda, em que os que ganham menos financiam as aposentadorias dos que recebem os maiores valores.

Todas essas evidências nos levam a crer que o sistema de seguridade social oficial necessita de ajustes e reformas urgentes. Algumas reformas foram realizadas em 1998. Observa-se que as principais modificações ocorridas tiveram enfoque na receita, deixando para depois correções nos critérios para concessão de benefícios.

Esse quadro evidencia que o sistema previdenciário brasileiro, apesar da sua importância, não está ajustado de forma a eliminar distorções existentes para que possa atender aos princípios da eqüidade, universalidade, solidariedade e redistribuição. É necessário aumentar a eficiência operacional do sistema previdenciário, porque tão importante quanto o volume de recursos gastos em benefícios é a eficiência do gasto e dos mecanismos de controle, de fiscalização e de transparência para a sociedade.

Apesar da Reforma Constitucional $n_{7}$ 20, o que se observou foram ajustes no

Regime Geral de Previdência Social administrada pelo INSS, que atingem a grande maioria da população, enquanto a concessão de benefícios para o Regime dos funcionários públicos permaneceu sem grandes modificações. A Emenda Constitucional teve como preocupação maior diminuir o déficit previdenciário. A distribuição dos benefícios de aposentadorias e pensões não foi modificada, e a tendência é a previdência social continuar a reproduzir a distribuição de renda vigente no país, concentrando a maior parte do valor dos benefícios nos segmentos mais ricos da sociedade. 
É preciso buscar o aperfeiçoamento de critérios e requisitos dos regimes de previdência, adotando conceitos e fundamentos da doutrina do sistema de previdência social, com o objetivo de diminuir as diferenças no valor dos benefícios dos trabalhadores.

Apesar de a previdência social exercer papel fundamental na diminuição da pobreza no Brasil, conforme afirma Brant (2001a), é saudável que as políticas públicas com caráter redistributivo sejam orientadas, principalmente, para os mais pobres, com o objetivo de diminuir a desigualdade na distribuição da renda.

Medidas de curto prazo, como a cobrança de contribuição previdenciária proporcional aos valores das aposentadorias e pensões, restabelecendo o princípio da equiidade contributiva, é imperativo. Dessa forma, o sistema sempre estaria em equilíbrio e garantiria justiça, porque cada um retiraria proporcionalmente ao que depositou.

No médio e longo prazo, o sistema previdenciário oficial deverá ser reestruturado, corrigindo as distorções existentes nos seus Regimes Previdenciários. Sabe-se que a origem da maior parte do déficit da previdência é proveniente do Regime dos Servidores Públicos, que recebem aposentadorias maiores do que o Regime Geral de Previdência Social. Não haveria problema se os aposentados do Regime dos Servidores públicos tivessem contribuído com valor suficiente para tanto. Porém, com o aumento crescente do déficit previdenciário, as aposentadorias desse regime deixam de ser uma questão de foro individual e passam a ser uma questão de toda a sociedade. É a sociedade que deverá responder se quer continuar a dirigir recursos para manter privilégios ou se faz uma reforma na previdência, visando diminuir tais distorções, redirecionando os gastos para os menos favorecidos.

Deve-se ter em vista, também, a arrecadação previdenciária do mercado de trabalho informal, cada vez mais presente no país. É necessário criar a possibilidade de contribuições menores, mesmo que isso resulte em benefício menor, mas seria, de todo 
modo, melhor do que manter um contingente enorme de trabalhadores à margem do sistema.

Para realizar uma boa reestruturação do sistema previdenciário, espera-se que algumas questões básicas sejam lembradas, porque são fundamentais para a sua permanência e bom desempenho. São elas:

$1^{\mathrm{a}}$ - o emprego dos recursos públicos será bem direcionado e atenderá também aos grupos de baixos rendimentos?

$2^{\mathrm{a}}$ - os regimes previdenciários oficiais existentes no Brasil oferecerão segurança futura?

$3^{\mathrm{a}}$ - sob o ponto de vista da eqüidade contributiva, será um sistema justo?

$4^{\mathrm{a}}$ - a previdência social será um instrumento de poupança e atenderá a uma de suas funções adicionais e importantes no processo de desenvolvimento?

É necessário que os especialistas em previdência social encontrem soluções e criem regras adequadas para resolver o quadro existente, repactuando direitos e obrigações. Também é preciso que o Congresso Nacional, responsável pela criação e aprovação de leis, aprove medidas corretas, aperfeiçoando a legislação e as políticas previdenciárias, embora isso seja dificultado pelas pressões de segmentos da sociedade que buscam manter privilégios. Sabe-se que esse é um tema politicamente delicado e que os prejuízos políticoseleitorais aparecem de imediato, enquanto que os benefícios da reforma do sistema ocorrerão gradualmente ao longo do tempo. Mesmo assim, quando se verifica que não haverá possibilidades de sustentar o atual modelo previdenciário, tais desgastes são necessários, para que não se cometa uma enorme irresponsabilidade para com os idosos deste país.

O ponto positivo que se tem observado com relação à previdência social é a intensa discussão e debate do sistema, procurando mostrar a toda população os seus problemas, tornando-a transparente, de modo a suscitar debates, pesquisas e manifestações que visem efetivamente acabar com as distorções existentes, criando condições para diminuir o déficit previdenciário. Espera-se que a previdência social seja mais um instrumento que contribua para diminuir a desigualdade da distribuição da renda no Brasil. 


\section{REFERÊNCIAS BIBLIOGRÁFICAS}

AMSBERG, J.V.; LANJOUW, P.; NEAD, K. A focalização do gasto social sobre a pobreza no Brasil. In: HENRIQUES, R. (Org.). Desigualdade e pobreza no Brasil. Rio de Janeiro: IPEA, 2000. cap.24, p.685-718.

ANDRADE, E.L.G. Envelhecimento e previdência social no Brasil. In: WONG,L.L.R. (Org.). $\mathrm{O}$ envelhecimento da população brasileira e o aumento da longevidade. Belo Horizonte: ABEP, 2001. cap.6, p.165-188.

BARR, N. Reforma das previdências: mitos, verdades e escolhas políticas. http://www.previdenciasocial.gov.br/docs/volume 09.pdf (21 maio 2002).

BARROS, R.P.; FOGUEL, M. N. Focalização dos gastos públicos sociais e erradicação da pobreza no Brasil. In: HENRIQUES, R. (Org.). Desigualdade e pobreza no Brasil. Rio de Janeiro: IPEA, 2000. cap.25, p.719-739.

BARROS, R.P.; MENDONÇA, R.; SANTOS, D. Incidência e natureza da pobreza entre idosos no Brasil. In: CAMARANO, A.A. (Org.). Muito além dos 60: os novos idosos brasileiros. Rio de Janeiro: IPEA, 1999. cap.7, p.221-250.

BARROS, R.P.; FIRPO, S.; MENDONÇA, R.; SANTOS, D. Aposentadoria e pobreza no Brasil (compact disc). In: ENCONTRO NACIONAL DE ECONOMIA, 28., Campinas, 2000. Campinas:ANPEC, 2000. 
BRANT, R. Desenvolvimento social, previdência e pobreza no Brasil. Conjuntura Social, v.12, n.2, p.7-63, abr./jun. 2001a.

BRANT, R. Reforma da previdência em um ambiente democrático. Conjuntura Social, v.12, n.2, p.65-117, abr./jun. 2001b.

CAMARANO, A.A. O idoso brasileiro no mercado de trabalho. Rio de Janeiro: IPEA, 2001. 22p. (Texto para Discussão, 830).

CAMARANO, A.A. Envelhecimento da população brasileira: uma contribuição demográfica. Rio de Janeiro: IPEA, 2002. 26p. (Texto para Discussão, 858).

CAMARANO, A.A.; BELTRÃO, K.I.; PASCOM, A.R.P.; MEDEIROS, M.; GOLDANI, A.M. Como vive o idoso brasileiro? In: CAMARANO, A.A. (Org.). Muito além dos 60: os novos idosos brasileiros. Rio de Janeiro: IPEA, 1999. cap.2, p.19-71.

CECHIN, J. A previdência social reavaliada - II. Conjuntura Social, v.13, n.1, p.7-54, jan./mar. 2002.

CORRÊA, A.M.C.J. Distribuição de rendimentos e pobreza na agricultura brasileira: 1981-1990. Piracicaba, 1995. 353p. Tese (Doutorado) - Escola Superior de Agricultura “Luiz de Queiroz”, Universidade de São Paulo.

DELGADO, G.C.; CARDOSO JUNIOR, J.C. O idoso e a previdência rural no Brasil: a experiência recente da universalização. In: CAMARANO, A.A. (Org) Muito além dos 60: os novos idosos brasileiros. Rio de Janeiro: IPEA, 1999. cap.11, p.319-343. 
DELGADO, G.C.; CARDOSO JUNIOR, J.C. Universalização de direitos sociais mínimos no Brasil: o caso da Previdência Rural nos anos 90. http://www.previdênciasocial.gov.br/docs/volume03.pdf (19 maio 2002).

ERCELAWN, A. Income inequality in rural Pakistan: a study of sample villages. Pakistan Journal of Applied Economics, n.3, p.1-28, 1984.

FEI, J.C.; RANIS, G.; KUO, S.W.Y. Growth and the family distribution of income by factor components. The Quarterly Journal of Economics, v.92, p.17-53, Feb. 1978.

FÍGOLI, M.G.B. Envelhecimento populacional e o comportamento das aposentadorias urbanas no Brasil. In: WONG, L.L.R. (Org.). O envelhecimento da população brasileira e o aumento da longevidade. Belo Horizonte: UFMG/Cedeplar, 2001. cap.5, p.127-163.

GASTOS de rico para uma previdência pobre. http://www6.via-rs.com.Br/esteditora/correio/4779/right.htm (02 jun. 2002).

HOFFMAnN, R. A subdeclaração dos rendimentos. São Paulo em Perspectiva, v.2, n.1, p.50-54, jan./mar. 1988.

HOFFMANN, R. Desigualdade e pobreza no Brasil no período 1979-90. Revista Brasileira de Economia, v.49, n.2, p.277-294, abr./jun.1995.

HOFFMANN, R. Distribuição de renda: medidas de desigualdade e pobreza. São Paulo: EDUSP, 1998. 275p. 
HOFFMANN, R. Desigualdade no Brasil: a contribuição das aposentadorias. www.eco.unicamp.br/projetos/rurbano.html. (17 out. 2002a)

HOFFMANN, R. Desigualdade e pobreza no Brasil no período 1979-99. www.eco.unicamp.br/projetos/rurbano.html. (17 out. 2002b).

HOFFMANN, R. Posse da terra, renda e condições de vida na agricultura brasileira (compact disc). In: CONGRESSO BRASILEIRO DE ECONOMIA E SOCIOLOGIA RURAL, 40., Passo Fundo, 2002. Anais. Brasília: SOBER, 2002c.

HOLZMANN, R.; PACKARD, T.; CUESTA, J. Ampliação da cobertura em sistemas previdenciários multi-pilar: limitantes e hipóteses, evidências preliminares e agenda de pesquisa futura.

http://www.previdenciasocial.gov.br/docs/volume 09.pdf (21 maio 2002).

INSTITUTO BRASILEIRO DE GEOGRAFIA E ESTATÍSTICA. Pesquisa Nacional por Amostra de Domicílios (compact disc). Rio de Janeiro, 1981, 1983-86, 198889, 1990, 1992-93, 1995-99 e 2001.

INSTITUTO DE ESTUDOS DO TRABALHO E SOCIEDADE. Desenvolvimento com justiça social: esboço de uma agenda integrada para o Brasil. http://saturno.no.com.br/noticia/leitura/pdf (28 abr. 2002).

INSTITUTO DE PESQUISA ECONÔMICA APLICADA. Relatório sobre o desenvolvimento Humano no Brasil. Brasília: PNUD, 1996. 185p.

INSTITUTO DE PESQUISA ECONÔMICA APLICADA. O Brasil na virada do milênio. Brasília, IPEA, 1997. v.2, p.55-74: Previdência social e saúde: perspectivas. 
JAMES, E. Novos sistemas previdenciários: experiências, evidências e questões pendentes. http://www.previdenciasocial.gov.br/docs/volume 09.pdf (21 maio 2002).

JAMES, E.; BROOKS, S. A economia política da reforma estrutural do sistema previdenciário.

http://www.previdenciasocial.gov.br/docs/volume 09.pdf (21 maio 2002).

MANKIW, N.G. Introdução à economia: princípios de micro e macroeconomia. Trad. de M.J.C. Monteiro. Rio de Janeiro: CAMPUS, 1999. cap.20, p.427-448: Distribuição de renda.

MARIANO, J.L.; LIMA, R.C. A desigualdade da renda rural no Nordeste: análise da desagregação do coeficiente de Gini e da sensibilidade do índice de bem-estar de Sen. Análise Econômica, v.16, n.29, p.103-118, mar. 1998.

MEDICI, A.C. Previdência social. Brasil em Números, v.6, p.107-117, 1998.

MITCHEL, O.S. Construindo um ambiente para a reforma da previdência nos países em desenvolvimento.

http://www.previdenciasocial.gov.br/docs/volume 09.pdf (21 maio 2002).

MOREIRA, M.M. Envelhecimento da população brasileira. Belo Horizonte, 1997. 149p. Tese (Doutorado) - Faculdade de Ciências Econômicas, Universidade Federal de Minas Gerais.

NAJBERG, S.; IKEDA,M. Previdência no Brasil: desafios e limites. In: GIAMBIAGI, F.; MOREIRA, M.M.(Ed.). A economia brasileira nos anos 90. Rio de Janeiro: BNDES, 1999. cap.3, p. 261-290. 
NEDER, H.D. Os efeitos das atividades não-agrícolas na distribuição de renda no meio rural (compact disc). In: CONGRESSO BRASILEIRO DE ECONOMIA E SOCIOLOGIA RURAL, 39., Recife, 2001. Anais. Brasília: SOBER, 2001.

NERI, M. Recursos existem, falta qualidade. Conjuntura Econômica, v.55, n.11, p.78-79, nov. 2001.

ORNÉLAS, W. O novo modelo previdenciário brasileiro: uma fase de transição. http://www.previdenciasocial.gov.br/07_08.htm (20 maio 2002).

ORNÉLAS, W.; VIEIRA, S.P. Novo rumo para a previdência brasileira. http://www.previdenciasocial.gov.br/07_09.htm (13 jun.2002).

PINHEIRO, V.C. Aspectos sociais da previdência no Brasil: o desafio de aumentar a cobertura. http://www.previdenciasocial.gov.br/docs/volume03.pdf (19 maio 2002).

PYATT, G.; CHEN, C.; FEI, J. The distribution of income by factor components. The Quarterly Journal of Economics, v.95, n.3, p.451-473, Nov. 1980.

RAMOS, C.A. Impacto distributivo do gasto público: uma análise a partir da PCV/1998. Rio de Janeiro: IPEA, 2000. 21p. (Texto para Discussão, 732).

RAMOS, L.R.A. A distribuição de rendimentos no Brasil: 1976/85. Rio de Janeiro: PEA, 1993. 135p. (Série IPEA, 141).

SANDRONI, P. Novíssimo dicionário de economia. São Paulo: Best Seller, 2001. 649 p.

SEN, A. On economic inequality. London: Clarendon Press, 1973. 188p. 
STEPHANES, R. Reforma da previdência sem segredos. 2.ed. Rio de Janeiro: Record, 1999. 244p.

THEIL, H. Economics and information theory. Amsterdam: North-Holland Publ., 1967. 488p.

THOMPSON, L. Mais velha e mais sábia: a economia dos sistemas previdenciários. http://www.previdenciasocial.gov.br/docs/volume 04.pdf (13 maio 2002)

WAJNMAN, S.; OLIVEIRA, A.M.H.C.P.; OLIVEIRA, E.L. A atividade econômica dos idosos no Brasil. In: CAMARANO, A.A. (Org.). Muito além dos 60: os novos idosos brasileiros. Rio de Janeiro: IPEA, 1999. cap.6, p.181-220. 